\title{
\#USGS
}

National Water-Quality Assessment (NAWQA) Program, National Synthesis on Volatile Organic Compounds (VOCs)

\section{Occurrence, Distribution, and Trends of Volatile Organic Compounds in the Ohio River and its Major Tributaries, 1987-96}

Water-Resources Investigations Report 99-4257

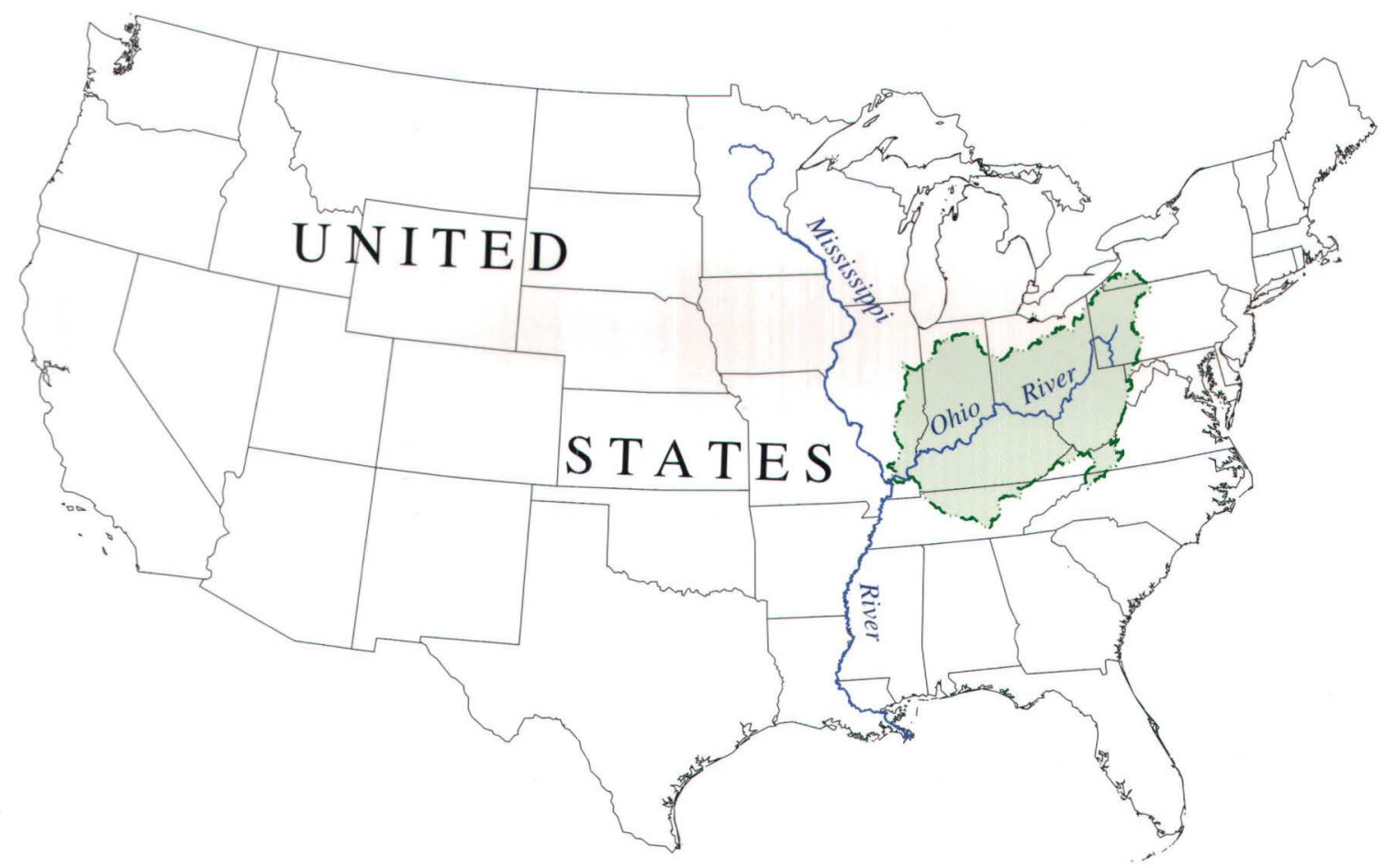

U.S. Department of the Interior

U.S. Geological Survey 


\section{Occurrence, Distribution, and Trends of Volatile Organic Compounds in the Ohio River and its Major Tributaries, 1987-96}

By Robert F. Lundgren and Thomas J. Lopes

Water-Resources Investigations Report 99-4257 


\section{U.S. Department of the Interior}

Bruce Babbitt, Secretary

\section{U.S. Geological Survey}

Charles G. Groat, Director

The use of firm, trade, and brand names in this report is for identification purposes only and does not constitute endorsement by the U.S. Geological Survey.

Rapid City, South Dakota: 1999

For additional information write to:

District Chief

U.S. Geological Survey

1608 Mt. View Road

Rapid City, SD 57702

Copies of this report can be purchased from:

\section{U.S. Geological Survey}

Branch of Information Services

Box 25286

Denver, CO 80225-0286 


\section{FOREWORD}

The mission of the U.S. Geological Survey (USGS) is to assess the quantity and quality of the earth resources of the Nation and to provide information that will assist resource managers and policymakers at Federal, State, and local levels in making sound decisions. Assessment of water-quality conditions and trends is an important part of this overall mission.

One of the greatest challenges faced by waterresources scientists is acquiring reliable information that will guide the use and protection of the Nation's water resources. That challenge is being addressed by Federal, State, interstate, and local water-resource agencies and by many academic institutions. These organizations are collecting water-quality data for a host of purposes that include: compliance with permits and water-supply standards; development of remediation plans for a specific contamination problem; operational decisions on industrial, wastewater, or watersupply facilities; and research on factors that affect water quality. An additional need for water-quality information is to provide a basis on which regional and national-level policy decisions can be based. Wise decisions must be based on sound information. As a society we need to know whether certain types of water-quality problems are isolated or ubiquitous, whether there are significant differences in conditions among regions, whether the conditions are changing over time, and why these conditions change from place to place and over time. The information can be used to help determine the efficacy of existing waterquality policies and to help analysts determine the need for and likely consequences of new policies.

To address these needs, the Congress appropriated funds in 1986 for the USGS to begin a pilot program in seven project areas to develop and refine the National Water-Quality Assessment (NAWQA) Program. In 1991, the USGS began full implementation of the program. The NAWQA Program builds upon an existing base of water-quality studies of the USGS, as well as those of other Federal, State, and local agencies. The objectives of the NAWQA

Program are to:

- Describe current water-quality conditions for a large part of the Nation's freshwater streams, rivers, and aquifers.
- Describe how water quality is changing over time.

- Improve understanding of the primary natural and human factors that affect water-quality conditions.

This information will help support the development and evaluation of management, regulatory, and monitoring decisions by other Federal, State, and local agencies to protect, use, and enhance water resources.

The goals of the NAWQA Program are being achieved through ongoing and proposed investigations of 59 of the Nation's most important river basins and aquifer systems, which are referred to as Study Units. These Study Units are distributed throughout the Nation and cover a diversity of hydrogeologic settings. More than two-thirds of the Nation's freshwater use occurs within the 59 Study Units and more than two-thirds of the people served by public watersupply systems live within their boundaries.

National synthesis of data analysis, based on aggregation of comparable information obtained from the Study Units, is a major component of the program. This effort focuses on selected water-quality topics using nationally consistent information. Comparative studies will explain differences and similarities in observed water-quality conditions among study areas and will identify changes and trends and their causes. The first topics addressed by the national synthesis are pesticides, nutrients, volatile organic compounds, and aquatic biology. Discussions on these and other waterquality topics will be published in periodic summaries of the quality of the Nation's ground and surface water as the information becomes available.

This report is an element of the comprehensive body of information developed as part of the NAWQA Program. The program depends heavily on the advice, cooperation, and information from many Federal, State, interstate, Tribal, and local agencies and the public. The assistance and suggestions of all are greatly appreciated.

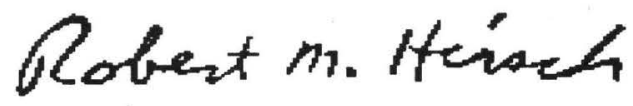

Robert M. Hirsch Chief Hydrologist 


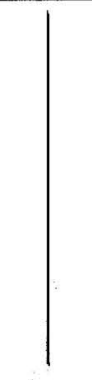




\section{CONTENTS}

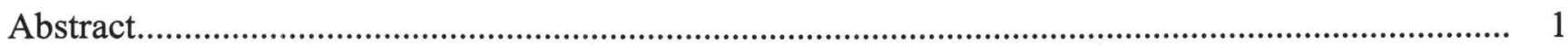

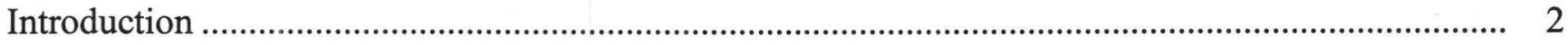

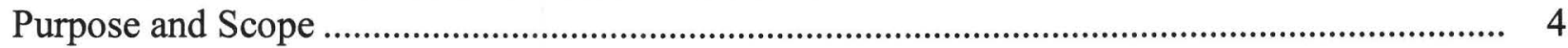

Description of Study Area........................................................................................................... 4

Previous Investigations ................................................................................................................ 5

Acknowledgments................................................................................................................. 7

Methods of Data Collection and Analysis ........................................................................................ 7

River Sampling.................................................................................................................. 7

Analytical Methods …………………............................................................................................. 7

Retrieval from STORET …………………………........................................................... 8

Statistical Methods .................................................................................................................. 8

Occurrence and Distribution of Volatile Organic Compounds .............................................................. 9

Basinwide Analysis ................................................................................................................ 9

Station-by-Station Analysis ....................................................................................................... 14

Comparison to Drinking-Water Regulations .................................................................................. 33

Trend Analysis........................................................................................................................ 36

Adjustment for Stream Discharge and Changes in Detection Limits .......................................... 36

Time Trend Results ...................................................................................................................... 37

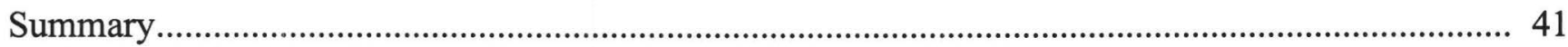

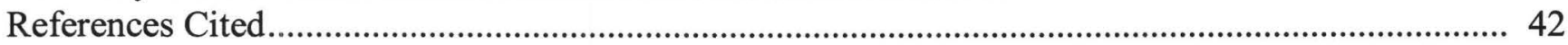

\section{FIGURES}

1. Map showing location of Ohio River Basin, Ohio River Valley Water Sanitation Commission (ORSANCO) monitoring stations, and U.S. Geological Survey (USGS) stream-gaging stations

2. Boxplots showing discharge at U.S. Geological Survey (USGS) stream-gaging stations on the Ohio River, 1987-96.

3. Bar chart showing number of volatile organic compounds (VOCs) detected in river-water samples from the Ohio River Basin, 1987-96

4. Graphs showing (A) frequencies of detection and (B) distribution of detected concentrations of volatile organic compounds (VOCs) in river-water samples from all monitoring stations sampled in the Ohio River Basin, 1987-96.

5. Graphs showing seasonal distribution of volatile organic compounds (VOCs) per month by (A) number of VOCs detected per sample and (B) percentage of detection for all river-water samples from the Ohio River Basin, 1987-96. 
6. Bar chart showing frequency of detection of volatile organic compounds (VOCS) during cooler and warmer months, Ohio River Basin, 1987-96.

7-21. Graphs showing (A) frequencies of detection and (B) distribution of detected concentrations of volatile organic compounds (VOCs) in river-water samples from the:

7. Allegheny River at Pittsburgh, Pa. (station AR7.40), Ohio River Basin, 1987-96......

8. Monongahela River at Becks Run, Pa. (station MR4.5), Ohio River Basin, 1987-96.

9. Ohio River at Neville Island, Pa. (station OR976.50), Ohio River Basin, 1987-96

10. Ohio River at Shippingport, Pa. (station OR946.1), Ohio River Basin, 1987-96.

11. Ohio River at East Liverpool, Ohio (station OR9408), Ohio

River Basin, 1987-96

12. Ohio River at Weirton, W. Va. (station OR9159), Ohio River Basin, 1987-96.

13. Ohio River at Wheeling, W. Va. (station OR894.2), Ohio

River Basin, 1987-96

14. Ohio River at Parkersburg, W. Va. (station OR790.7), Ohio

River Basin, 1987-96

15. Kanawha River at St. Albans, W. Va. (station KR38.3), Ohio River Basin, 1987-96.

16. Ohio River at Huntington, W. Va. (station OR674.1), Ohio

River Basin, 1987-96

17. Ohio River at Portsmouth, Ohio (station OR630.9), Ohio River Basin, 1987-96

18. Ohio River at Cincinnati, Ohio (station OR518.2), Ohio River Basin, 1987-96

19. Ohio River at Louisville, Ky. (station OR380.4), Ohio River Basin, 1987-96....

20. Ohio River at Evansville, Ind. (station OR189.5), Ohio River Basin, 1987-96

21. Ohio River at Paducah, Ky. (station OR45.5), Ohio River Basin, 1987-96

22. Bar charts showing frequencies of detection of trichloromethane and benzene in river-water samples from the Ohio River Valley Water Sanitation Commission (ORSANCO) monitoring stations, Ohio River Basin, 1987-96

23. Graph showing sum of the median concentrations and percentage of detection of any of one or more volatile organic compounds (VOCs) in river-water samples from the Ohio River Valley Water Sanitation Commission (ORSANCO) monitoring stations, Ohio River Basin, 1987-96 
24. Boxplots showing number of significant rank correlations between detectable concentrations of volatile organic compounds (VOCs) in river-water samples from individual Ohio River Valley Water Sanitation Commission (ORSANCO) monitoring stations, Ohio River Basin, 1987-96

25. Boxplots showing seasonal distribution of number of volatile organic compounds (VOCs) detected per month in river-water samples from the Ohio River at Shippingport, Pa. (station OR946.1), and at Wheeling, W. Va. (station OR894.2), 1987-96.

26. Graph showing time series of mean monthly concentrations of (A) trichloromethane in river-water samples from the Ohio River at Cincinnati, Ohio (station OR518.2), and (B) benzene in river-water samples from the Kanawha River at St. Albans, W. Va. (station KR38.3), 1987-96

27. Graph showing time series of mean monthly concentrations of 1,2-dichloroethane in river-water samples from the Ohio River at Paducah, Ky. (station OR45.4), 1987-96.

28. Graph showing time series of mean monthly concentrations of trichloromethane in river-water samples from the Ohio River at Wheeling, W. Va. (station OR894.2), showing two monotonic trends, for 1987-93 and 1994-96

\section{TABLES}

1. Volatile organic compounds (VOCs) analyzed by the Ohio River Valley Water Sanitation Commission (ORSANCO)

2. Ohio River Valley Water Sanitation Commission (ORSANCO)

Organic Detection System (ODS) monitoring stations used for this study

3. Statistical summary of volatile organic compounds (VOCs) detected in all river-water samples from the Ohio River Basin, 1987-96.

4. Number of samples with volatile organic compound (VOC) pairs detected in river-water samples from the Ohio River Basin, 1987-96

5. Statistically significant correlations between concentrations of volatile organic compounds (VOCs) detected in river-water samples from the Ohio River Basin, 1987-96

6. Volatile organic compounds (VOCs) with significant differences in detections in river-water samples between cooler and warmer months, Ohio River Basin, 1987-96

7. Number of river-water samples from individual Ohio River Valley Water Sanitation Commission (ORSANCO) monitoring stations with detected volatile organic compounds (VOCs), 1987-96. 
8. Statistical summary of volatile organic compounds (VOCs) in river-water samples from the Ohio River Valley Water Sanitation Commission (ORSANCO) monitoring stations, Ohio River Basin, 1987-96

9. Number of samples with volatile organic compound (VOC) pairs detected in river-water samples from individual monitoring stations, Ohio River Basin, 1987-96

10. Statistically significant correlations between detected concentrations of volatile organic compounds (VOCs) in river-water samples from individual Ohio River Valley Water Sanitation Commission (ORSANCO) monitoring stations, Ohio River Basin, 1987-96

11. Human-health concerns, drinking-water regulations, and exceedances of regulations for volatile organic compounds (VOCS) detected in river-water samples from the Ohio River Valley Water Sanitation Commission (ORSANCO) monitoring stations, Ohio River Basin, 1987-96

12. Spearman correlation coefficients between stream discharge and detected concentrations of trichloromethane, 1987-96

13. Results of seasonal Kendall test for trends on monthly mean concentrations of volatile organic compounds (VOCS) in river-water samples from the Ohio River Valley Water Sanitation Commission (ORSANCO) monitoring stations, Ohio River Basin, 1987-96

14. Results of seasonal Kendall test for trends on monthly percentage of detections in river-water samples from the Ohio River Valley Water Sanitation Commission (ORSANCO) monitoring stations, Ohio River Basin, 1987-96 


\begin{tabular}{rll}
\hline Multiply & By & To obtain \\
\hline cubic foot per second $\left(\mathrm{ft}^{3} / \mathrm{s}\right)$ & 0.02832 & cubic meter per second \\
cubic meter per second per square $\mathrm{kilometer}$ & liter \\
gallon $(\mathrm{gal})$ & 3.785 & pound force per square inch \\
microgram per liter $(\mu \mathrm{g} / \mathrm{L})$ & 0.1450377 & part per billion \\
microgram per liter per year $[(\mu \mathrm{gg} / \mathrm{L}) / \mathrm{yr}]$ & 1.0 & part per billion per year \\
$\mathrm{mile}(\mathrm{mi})$ & 1.0 & kilometer \\
milliliter $(\mathrm{mL})$ & 0.0338 & ounce \\
pound $(\mathrm{lb})$ & 453.6 & gram \\
square mile $\left(\mathrm{mi}^{2}\right)$ & 259.0 & hectare \\
ton & 0.9072 & megagram \\
& & \\
\hline
\end{tabular}

Temperature in degrees Celsius $\left({ }^{\circ} \mathrm{C}\right)$ or degrees Fahrenheit $\left({ }^{\circ} \mathrm{F}\right)$ may be converted by the equations:

$$
\begin{aligned}
& { }^{\circ} \mathrm{C}=5 / 9\left({ }^{\circ} \mathrm{F}-32\right) \\
& { }^{\circ} \mathrm{F}=9 / 5\left({ }^{\circ} \mathrm{C}\right)+32
\end{aligned}
$$

\section{DEFINITION OF TERMS}

CAS. Chemical Abstract Services.

IUPAC. International Union of Pure and Applied Chemistry.

MCL. Maximum contaminant level.

MDL. Minimum detection level.

NAWQA. National Water-Quality Assessment Program.

ODS. Organics Detection System.

ORSANCO. Ohio River Valley Water Sanitation Commission.

STORET. Storage and Retrieval System.

THM. Trihalomethane.

USEPA. U.S. Environmental Protection Agency.

USGS. U.S. Geological Survey.

VOC. Volatile organic compound. 


\title{
Occurrence, Distribution, and Trends of Volatile Organic Compounds in the Ohio River and its Major Tributaries, 1987-96
}

\author{
By Robert F. Lundgren and Thomas J. Lopes
}

\begin{abstract}
The Ohio River is a source of drinking water for more than 3 million people. Thus, it is important to monitor the water quality of this river to determine if contaminants are present, their concentrations, and if water quality is changing with time. This report presents an analysis of the occurrence, distribution, and trends of 21 volatile organic compounds (VOCs) along the main stem of the Ohio River and its major tributaries from 1987 through 1996. The data were collected by the Ohio River Valley Water Sanitation Commission's Organics Detection System, which monitors daily for VOCs at 15 stations. Various statistical methods were applied to basinwide data from all monitoring stations and to data from individual monitoring stations.
\end{abstract}

For the basinwide data, one or more VOCs were detected in 45 percent of the 44,837 river-water samples. Trichloromethane, detected in 26 percent of the samples, was the most frequently detected VOC followed by benzene ( 11 percent), methylbenzene ( 6.4 percent), and the other 18 VOCs, which were detected in less than 4 percent of the samples. In samples from 8 of the 15 monitoring stations, trichloromethane was also the most frequently detected VOC. These stations were generally near large cities along the Ohio River. The median trichloromethane concentration was 0.3 microgram per liter $(\mu \mathrm{g} / \mathrm{L})$, and concentrations ranged from less than 0.1 to $125.3 \mu \mathrm{g} / \mathrm{L}$. Most of the VOCs had median detected concentrations that ranged from 0.1 to $0.4 \mu \mathrm{g} / \mathrm{L}$ for the basinwide data and for samples from individual stations. Samples from stations in the upstream part of the basin and from the Kanawha River had the highest median concentrations. Ninety-nine percent of the detected VOC concentrations were within U.S. Environmental Protection Agency drinking-water regulations. Of the 268 exceedances of drinking-water regulations, 188 were due to the detection of 1,2-dichloroethane prior to 1993 in samples from the monitoring station near Paducah, Ky.

Time trend analyses indicated that most VOCs had no trend in samples at most monitoring stations because they were detected infrequently. At one or more stations, 14 VOCs had decreasing trends in monthly mean concentrations that ranged from -0.01 to $-0.42 \mu \mathrm{g} / \mathrm{L}$ per year. Nine VOCs had significant decreasing trends in percentage detection that ranged from -1.08 to -12.90 percent per year. These trends suggest that source-control efforts are working and that water quality is improving. 


\section{INTRODUCTION}

The Ohio River is the largest tributary to the Mississippi River (fig. 1). One-third of the water carried into the Gulf of Mexico by the Mississippi originates from the Ohio River. The river is used for recreational activities, has many historical sites, supports a diverse wildlife population, and is a major transport route with more than 250 million tons of cargo transported annually (Tennant and others, 1992). The Ohio River also provides large quantities of water for industries and is a source of drinking water for many cities and towns along its banks. The quality of the Ohio River is critical to the more than 3 million people that depend on it as a source of drinking water (Tennant and others, 1992; Ohio River Valley Water Sanitation Commission, 1994). Thus, it is important to monitor the water quality of the Ohio River to determine if contaminants are present, their concentrations, and if water quality is changing with time.

The Ohio River Valley Water Sanitation Commission (ORSANCO), established on June 30, 1948 , coordinates public utility monitoring in the Ohio River drainage basin (Tennant and others, 1992). In 1978, ORSANCO implemented the Organics Detection System (ODS) to monitor volatile organic compounds (VOCs) and other contaminants from accidents and spills and to identify exceedances of drinking-water regulations. Data from the ODS are used by ORSANCO to promptly notify downstream drinking-water utilities when toxic substances in the waterway could contaminate drinking water (Ohio River Valley Water Sanitation Commission, 1981). The ORSANCO monitoring stations are located primarily near major sources of potential pollution and public water-supply intakes (Ohio River Valley Water Sanitation Commission, 1981). Each station has adequate laboratory facilities and personnel to participate in the program. Currently (1999), the ODS monitors for 21 VOCs at 15 stations along the Ohio, Allegheny, Monongahela, and Kanawha Rivers (fig. 1).

VOCs are chemicals that contain organic carbon and have a minimum vapor pressure of $0.13 \mathrm{kPa}$ at $20^{\circ} \mathrm{C}$ at sea level (Kotzias and Sparta, 1993). This means they can become more than 0.01 percent of the air in a closed space. VOCs have chemical and physical properties that allow the compounds to move freely between water and air (Rathbun, 1998). In general, VOCs have low molecular weights, high vapor pressures, and low-to-medium water solubilities (Rathbun, 1998). VOCs are found in many natural materials such as plant matter (Helmig and others, 1999) but are found mostly in synthetic materials. These compounds occur in commercial products such as gasoline, paints, adhesives, solvents, wood preservatives, dry-cleaning agents, pesticides, cosmetics, correction fluid, and refrigerants (Bloemen and Burn, 1993). VOCs also occur in combustion exhaust (Hoekman, 1992; Minear and Amy, 1995) and in chlorinated drinking water due to the reaction of free chlorine with dissolved organic matter.

Although inhalation is the main route of exposure for most VOCs, drinking water also can be an important route for these compounds (Wallace, 1993). Exposure to VOCs in drinking water is a human-health issue because they are toxic at low microgram-per-liter $(\mu \mathrm{g} / \mathrm{L})$ concentrations (Swan and others, 1998).

Understanding the occurrence, distribution, and trends of contaminants is important to the people that depend on the Ohio River as a source of drinking water. These goals are common to the U.S. Geological Survey (USGS) National Water-Quality Assessment (NAWQA) Program. The NAWQA Program was implemented by the USGS in 1991 to systematically assess the quality of the Nation's water resources. The primary goals of NAWQA are to describe the status and trends in the quality of a large, representative part of the Nation's water resources and to identify and describe the primary factors affecting water quality. The NAWQA Program describes water-quality conditions in more than 50 major river basins and aquifer systems across the Nation (Gilliom and others, 1995) but does not include the main stem of the Ohio River. Therefore, a retrospective analysis of data from ORSANCO's ODS was conducted to help fill a void in the NAWQA Program by assessing VOCs in this large river and its major tributaries that are used by public water suppliers. The study area is the Ohio River Basin (fig. 1).

The NAWQA Program has national synthesis teams focused on groups of contaminants and aquatic biota, including VOCs, pesticides, nutrients, trace elements, and aquatic ecology. In 1994, the VOC synthesis team was formed because of the widespread 


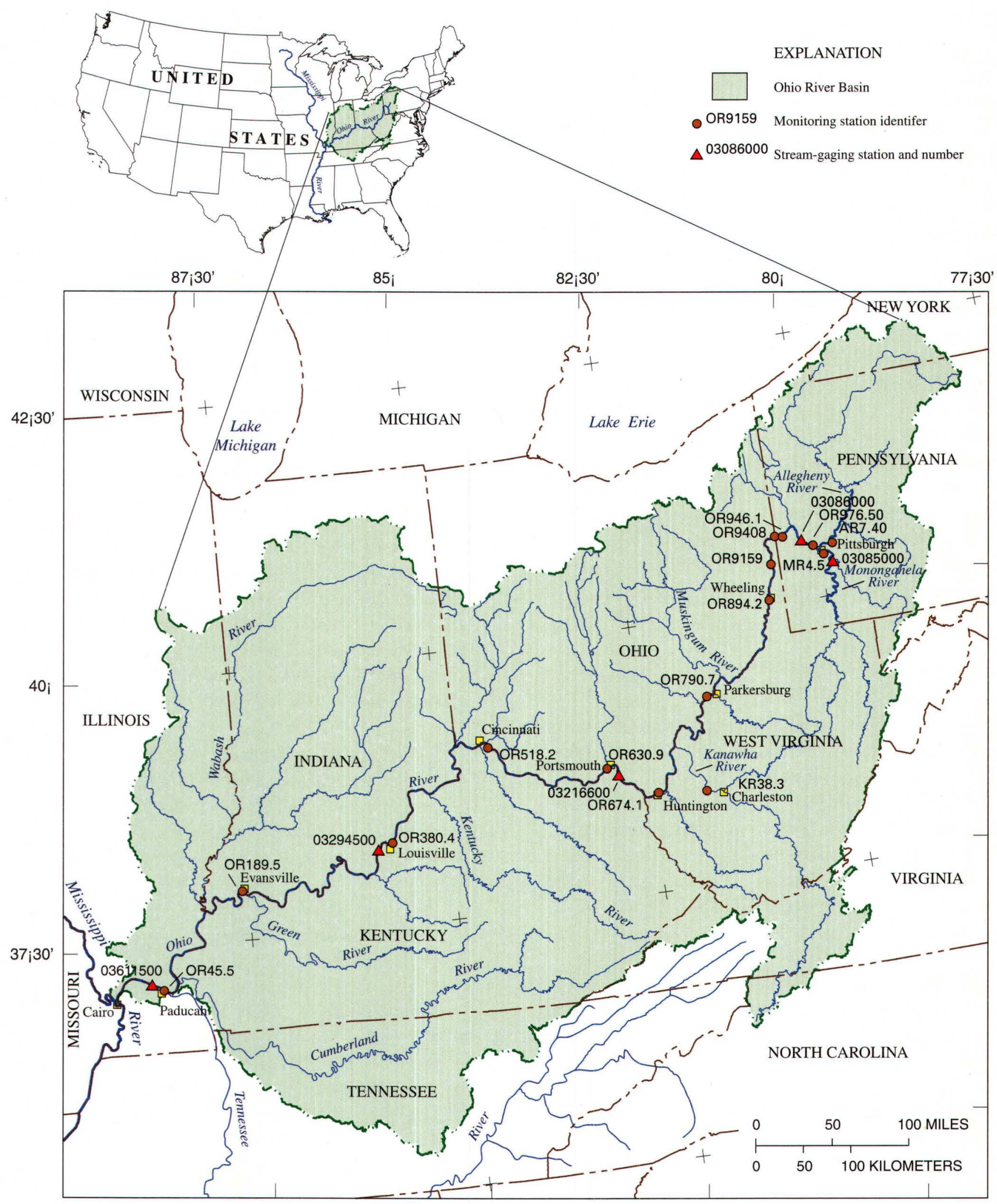

Base from U.S. Geological Survey digital data, 1:2,000,000, 1972

Albers Equal-Area Conic projection

Standard parallels $29 ; 30$ ' and $45 ; 30$ ', central meridian $96 ;$

Figure 1. Location of Ohio River Basin, Ohio River Valley Water Sanitation Commission (ORSANCO) monitoring stations, and U.S. Geological Survey (USGS) stream-gaging stations. 
occurrence of these compounds and the lack of information on factors related to their occurrence. The NAWQA Program is assessing VOCs in streams that drain basins with mostly residential and commercial land use (Lopes and Price, 1997), in public-supply aquifers, and in aquifers underlying recent (1970 to 1990) residential and commercial land use in large metropolitan areas (Squillace and Price, 1996).

Fifty-five VOCs, referred to as "target analytes," were selected for study because they are known or suspected carcinogens, they cause other human-health problems, or they frequently occur in surface water and ground water (Bender and others, 1999). The 21 VOCs analyzed by ORSANCO (table 1 at end of report) also are NAWQA target analytes. VOCs are identified by their International Union of Pure and Applied Chemistry (IUPAC) compound name throughout this report, except where U.S. Environmental Protection Agency Storage and Retrieval (STORET) System parameter codes are used in tables for compactness. The VOCs are listed in alphabetical order in table 1 and in order of the basinwide detection frequency throughout the remainder of this report.

\section{Purpose and Scope}

This report presents an analysis of the occurrence, distribution, and trends of VOCs in the Ohio River and its major tributaries from 1987 through 1996. Specific objectives of this analysis were to: (1) summarize VOC detections and concentrations; (2) determine if concentrations vary spatially and seasonally; and (3) determine if trends in concentrations are increasing, decreasing, or constant.

Initially, 16 VOCs were analyzed in daily samples of river water collected at 11 ORSANCO monitoring stations. By 1980 , the list of VOCs had expanded to 22 . These 22 VOCs were selected because they are known contaminants in the Ohio River, because industries along the river use these compounds, and because participating agencies can detect them at a concentration of $0.1 \mu \mathrm{g} / \mathrm{L}$. Bromochloromethane is no longer monitored because ORSANCO uses it in their analytical method to detect other compounds.

Instrumentation at the original 11 ORSANCO monitoring stations was upgraded in 1986 and January
1987. Upgraded instruments were installed at two additional stations in July 1987 and at two more stations in 1990 for a total of 15 . Data used in this report were collected starting on January 1, 1987, or when the upgraded instruments began service. The last data used in this report were collected December 31, 1996 , the last full year of data that were available when this study began. The original 11 stations were missing less than 1 month of data for the 10 -year period.

Stations that began service in 1990 and that had at least 6 full years of data are the Ohio River at Shippingport, $\mathrm{Pa}$. (station OR946.1), and the Ohio River at Weirton, W. Va. (station OR9159) (table 2 at end of report).

\section{Description of Study Area}

The Ohio River drains an area of $203,900 \mathrm{mi}^{2}$ in the north-central United States. The Ohio River is formed by the confluence of the Allegheny and Monongahela Rivers at Pittsburgh, Pa., and flows $981 \mathrm{mi}$ in a generally southwest direction to join the Mississippi River near Cairo, Ill. The main stem of the Ohio River flows through or borders six StatesPennsylvania, Ohio, West Virginia, Kentucky, Indiana, and Illinois. The Kanawha River is a heavily industrialized major tributary to the Ohio River.

The Ohio River drainage basin comprises about 5 percent of the land area and contains about 10 percent of the population of the United States (Ohio River Valley Water Sanitation Commission, 1994).

Twenty-nine communities with populations ranging in size from 1,000 to more than 2 million people use the Ohio River as a source of drinking water. These communities include Pittsburgh, Cincinnati, Louisville, and other towns that have a combined daily use of more than 500 million gallons of river water (Tennant and others, 1992). Major industries within the basin include mining of coal and production of steel and petrochemicals. Wastewater is discharged to the river from 194 municipal wastewater facilities and 383 industrial facilities (Tennant and others, 1992). Along the Ohio River are 49 electric-power-generating facilities, most of which are coal and hydroelectric facilities (Ohio River Valley Water Sanitation Commission, 1994).

Flow in the Ohio River is regulated by a series of locks and 20 dams operated by the U.S. Army Corps of 
Engineers to allow year-round commercial navigation: The median daily discharge at four USGS streamgaging stations, each located within $10 \mathrm{mi}$ of an ORSANCO monitoring station, ranged from 28,000 $\mathrm{ft}^{3} / \mathrm{s}$ in the upstream part of the Ohio River (station 03086000 ) to $218,000 \mathrm{ft}^{3} / \mathrm{s}$ near the Mississippi River (station 03611500 , fig. 2). In the $931 \mathrm{mi}$ between these stream-gaging stations, median stream discharge increases by a factor of about 8 and by about $1 \mathrm{ft}^{3} / \mathrm{s}$ per square mile of drainage area.

\section{Previous Investigations}

Data collected by ORSANCO have been used to identify sources of VOCs and other hazardous chemicals and to recommend corrective actions. Monitoring has shown that approximately one-half of the riverwater samples collected from the Ohio River and its major tributaries contained one or more of the 21 VOCs at a concentration of $0.1 \mu \mathrm{g} / \mathrm{L}$ or greater (Tennant and others, 1992). The most frequently detected VOCs in the Ohio River and its major tributaries were compounds used in gasoline and commercial and industrial processes, and byproducts from the chlorination of water. Most notably, trichloromethane was detected in more than 90 percent of the daily samples at some stations. During chlorination of drinking water and wastewater, byproducts such as trichloromethane and other trihalomethanes (THMs) are produced and contaminate the finished water (Bellar and others, 1974; Rook, 1974; International Agency for Research on Cancer, 1991; Minear and Amy, 1995). Trichloromethane also is used as a solvent for fats, oils, rubber, waxes, resins, and the manufacture of rubber (Lucius and others, 1989; Pankow and Cherry, 1996). The U.S. Environmental Protection Agency (USEPA) has set a Maximum Contaminant Level (MCL) of $100 \mu \mathrm{g} / \mathrm{L}$ for total THMs because these compounds may cause human cancer (U.S. Environmental Protection Agency, 1994, 1996).

Benzene, a known human carcinogen, and methylbenzene commonly were detected in the Ohio River Basin (Tennant and others, 1992) and occasionally are detected in drinking-water supplies at low concentrations (Westrick and others, 1984; Hadley, 1988b). Benzene and methylbenzene are components of gasoline (Hadley, 1988a, 1988b). Benzene is used in industry as a solvent and in chemical and pharma- ceutical production. Synthesis of styrenes, phenols, cyclohexanes, and other organic chemicals account for 86 percent of the industrial use of benzene (U.S. Environmental Protection Agency, 1985). The remaining industrial use of benzene primarily is in the production of detergents, pesticides, solvents, and paint removers. Methylbenzene is a solvent that commonly is used in paint, printing ink, and adhesives. In 1996, methylbenzene was one of the chemicals most widely released into the environment (U.S. Environmental Protection Agency, 1998). Benzene and methylbenzene, which often occur together with other aromatic compounds, can be released into waterways during the storage, transport, and disposal of petroleum products and from discharges of industrial and municipal effluents. In the United States, gasoline and oil spills account for about 90 percent of all releases of methylbenzene into water (Environment Canada, 1993).

\section{A study was undertaken by ORSANCO to} identify trends of VOCs in the Ohio River Basin for 1980-89. Seven compounds were used in the trend analysis on the basis of data-selection criteria (Ohio River Valley Water Sanitation Commission, 1992). The results indicated that most of the compounds analyzed for trends had significantly decreasing percentage detections, signifying improving water quality. Although the origin of organic contaminants in the river water is not known, it is suspected that they are from point-source discharges that are not monitored, ground-water contamination, and possibly nonpoint sources such as urban runoff (Ohio River Valley Water Sanitation Commission, 1994).

A primary responsibility of ORSANCO is the detection and interstate reporting of spills into the Ohio River (Ohio River Valley Water Sanitation Commission, 1994). ORSANCO receives notice of all reported spills into the Ohio River that may threaten water supplies and ensures that appropriate agencies are notified. When a spill is reported that may potentially affect downstream water-supply intakes, ORSANCO uses a computer model to estimate the arrival times, concentrations, and duration of the plume at the intakes. A high incidence of spills occurred from 1988 to 1991 (Ohio River Valley Water Sanitation Commission, 1994). The number of reported spills into the Ohio River decreased from 1991 to 1993, although the reason for the decrease was unknown. From 1991 to 1993, about 300 spills occurred in the upstream 


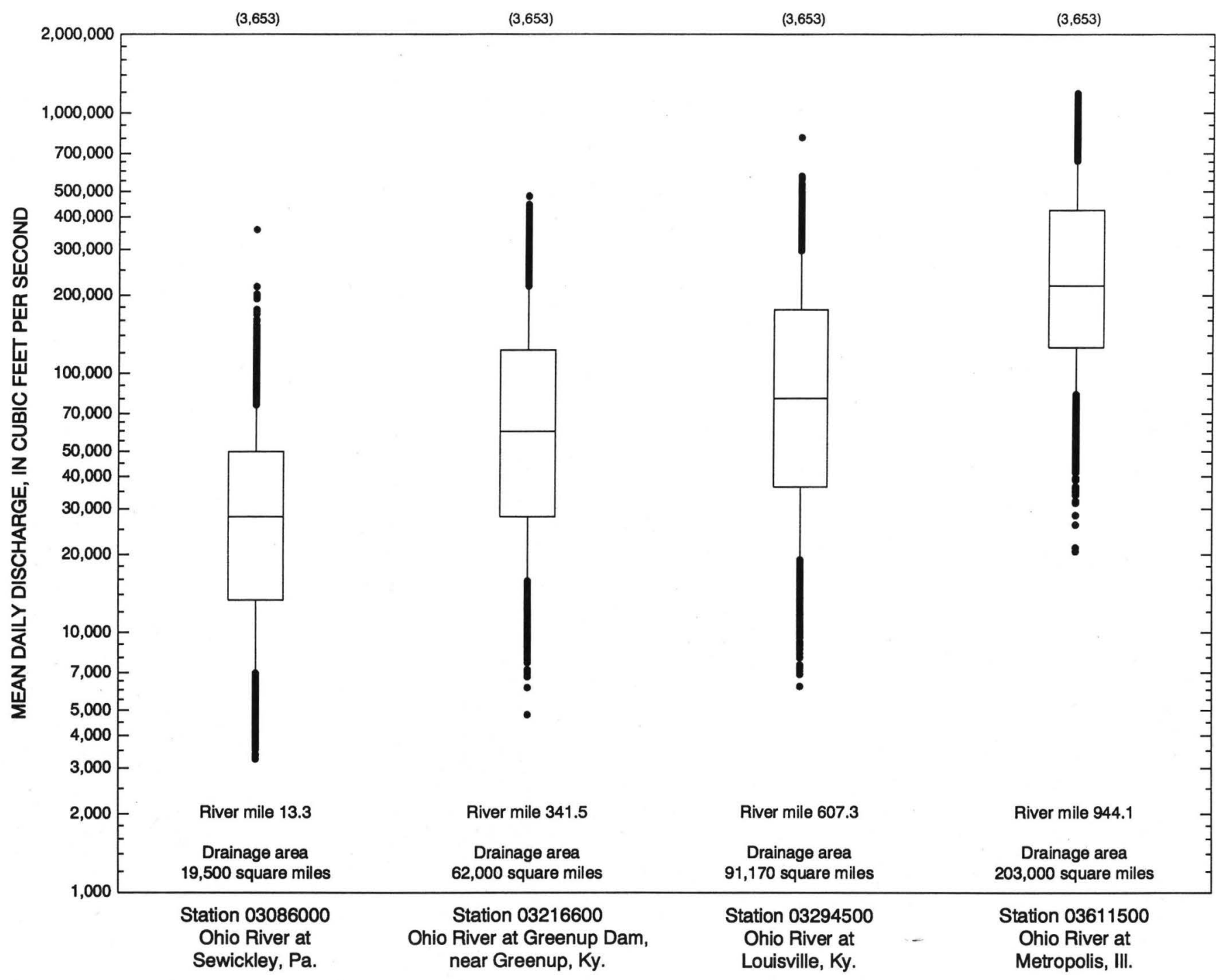


one-half of the Ohio River compared to about 70 spills in the downstream one-half of the river. Most spills were petroleum-related products in the upstream-most $100 \mathrm{mi}$ of the Ohio River. The sources of many spills, such as oil sheens, are unknown. However, spills tend to occur in reaches with industry and wastewater discharges. The relation between spills and commercial navigation has not been investigated.

In March 1993, a spill of approximately 500,000 lbs of methylbenzene occurred just downstream from the New Albany water-supply intake at Ohio River mile 609.6 in the Louisville, Ky., metropolitan area (Ohio River Valley Water Sanitation Commission, 1994). ORSANCO established a temporary monitoring station at Cannelton Dam located $110 \mathrm{mi}$ downstream from the spill site and $70 \mathrm{mi}$ upstream from Evansville, Ind., site of the nearest downstream public water-supply intake. ORSANCO modeled the transport of the compound and estimated the time of travel and concentrations of methylbenzene at Cannelton Dam. River-water samples were collected to bracket the model estimates. The estimated and actual traveltimes, about 30 hours, were within 10 percent and concentration estimates were judged reasonable. Peak methylbenzene concentrations at the Evansville intake were about $15 \mu \mathrm{g} / \mathrm{L}$, much less than the USEPA MCL drinking-water regulation of $1,000 \mu \mathrm{g} / \mathrm{L}$ (Ohio River Valley Water Sanitation Commission, 1994).

\section{Acknowledgments}

The authors thank Peter Tennant, Jason Heath, Jonathan McSayles, and Donna Beatsch of the Ohio River Valley Water Sanitation Commission for their assistance in retrieving and working with the data and for their review comments.

\section{METHODS OF DATA COLLECTION AND ANALYSIS}

Specific procedures for sample collection and analysis and laboratory protocol are described in detail by ORSANCO (1981). Procedures and protocols are summarized in the following sections.

\section{River Sampling}

The ODS operates in two modes, routine daily monitoring and variable-frequency spill tracking. Routine daily samples were collected from raw-water intake lines at water utilities and industries prior to any chemical treatment. These samples were collected as single-point grab samples from intakes near the bank of the river, rather than integrated across the river cross section. Thus, data may not be representative of conditions throughout the river cross section. The tap from which samples were collected was flushed for 2 to 3 minutes, and the flow was adjusted to minimize entrained air in the sample and to ensure complete filling.

A complete set of daily samples consisted of duplicate 50-mL raw-water samples collected in pre-cleaned amber or clear vials (per USEPA guidelines) and duplicate $50-\mathrm{mL}$ vials of organic-free water (Ohio River Valley Water Sanitation Commission, 1981). The bottles were labeled with the collection date, time, and location, and stored at $4^{\circ} \mathrm{C}$ until analysis. For routine daily samples, the duplicate sample usually was not analyzed, and the vials were cleaned for the next day's sampling. For tracking a spill, samples were collected more frequently, and a duplicate raw-water sample usually was analyzed.

\section{Analytical Methods}

River-water samples from all of the ORSANCO monitoring stations were analyzed for the 21 target VOCs (table 1), usually within 1 hour of collection, using an analytical procedure that is based on USEPA methods 502.1 and 502.2 (Ohio River Valley Water Sanitation Commission, 1981). Six aromatic VOCs were analyzed with method 502.2, and the remaining 15 VOCs were analyzed with method 502.1. These methods use purge-and-trap gas chromatography in combination with a series of detectors, including an electron capture detector, a photoionization detector, and a flame ionization detector. The detectors used vary among the stations and are sensitive to submicrogram-per-liter levels. One organic-free water sample was spiked with an internal standard and analyzed to test the instrument's qualitative and quantitative accuracy. 
The minimum detection level (MDL) for VOCs was $0.1 \mu \mathrm{g} / \mathrm{L}$ for the initial period of record at all stations. The MDL was decreased to $0.05 \mu \mathrm{g} / \mathrm{L}$ after 1992 when ORSANCO started using MDL determination studies (Jonathan McSayles, ORSANCO, written commun., 1998). For unknown reasons, methylbenzene and ethylbenzene were reported only in samples from October 1, 1991, to the end of the period of record. Thus, data for these two VOCs were available for only about one-half the samples collected at most stations.

Chromatographs of routine daily samples were compared to a reference chromatograph for each station to determine if typical concentrations measured at the site were exceeded. ORSANCO defines an excessive concentration to be any VOC concentration greater than $25 \mu \mathrm{g} / \mathrm{L}$ or greater than 10 times the concentration of the same VOC on the previous day (Ohio River Valley Water Sanitation Commission, 1981). Excessive concentrations triggered a warning, and the duplicate raw-water sample was shipped to a contract analytical laboratory for confirmation by gas chromatography/mass spectrometry.

\section{Retrieval from STORET}

Data from the ODS were entered into the USEPA's STORET System. Data from 1987 through 1996 were retrieved from STORET for this study. The data are stored under agency code 31ORWUNT and come in two forms: (1) spill monitoring data and (2) daily sample data. Daily sample data were used in this study because the data are of higher quality for VOCs than the spill data (Peter Tennant, ORSANCO, oral commun., 1997). Information associated with each sample includes the station name, station latitudelongitude, sampling date, STORET parameter code, concentration in micrograms per liter, remark code, and streamflow discharge in cubic feet per second. Streamflow data are modeled estimates from the National Weather Service. VOC data are reported with one of three remark codes. Remark code ' $U$ ' indicates that the VOC was analyzed but was not detected, '@' is a placeholder that means the VOC was detected at the reported concentration, and ' $\mathrm{M}$ ' indicates the VOC was detected but not quantified.
A VOC was considered detected if it had an ' $M$ ' or '@' remark code. Three ORSANCO monitoring stations-Monongahela River at Becks Run, Pa. (station MR4.5); Kanawha River at St. Albans, W. Va. (station KR38.3); and Ohio River at Louisville, Ky. (station OR380.4) - had sample concentrations reported as less than the MDL of $0.05 \mu \mathrm{g} / \mathrm{L}$. For statistical analyses, concentrations reported as less than $0.05 \mu \mathrm{g} / \mathrm{L}$ were considered nondetections. Nondetections were assumed equal to zero. This does not mean necessarily that the compound was totally absent, but rather it may have been present at very low and unspecified concentrations (Ohio River Valley Water Sanitation Commission, 1994).

\section{Statistical Methods}

Descriptive and nonparametric statistics, presented in tabular and graphical formats, are used in this report to evaluate the occurrence, distribution, and trends in VOC concentrations. Nonparametric statistics are not affected by conventions of assigning concentrations to nondetections and unquantified detections (Helsel and Hirsch, 1992). Statistics are done for a basinwide analysis, which uses combined data from all monitoring stations, and for a stationby-station analysis, which uses data from individual monitoring stations. The period of record used for statistical analysis at individual ORSANCO monitoring stations is indicated in table 2. The statistical program SAS (Statistical Analysis Software) (SAS Institute, Inc., 1990) was used to calculate the descriptive and nonparametric statistics.

Descriptive statistics and boxplots (Helsel and Hirsch, 1992) are used to report the range of detected constituent concentrations in the basin, and graphs are used to show the spatial distribution of median constituent concentrations. Descriptive statistics include the number of observations, percentage of VOC detections, and mean, standard deviation, median, minimum, and maximum detected concentrations. The percentage of detection was calculated by dividing the number of detections (' $M$ ' or '@' remark codes) by the number of samples and multiplying by 100 .

Spearman rank-order correlations (Helsel and Hirsch, 1992; Sheskin, 1997) are used to determine if concentrations of different VOCs are related. The 
Spearman rank-order correlation coefficient is a nonparametric statistic that is calculated from the ranks of the data and is unaffected by outliers. The rank-sum test is used to determine if VOCs are detected more frequently during cooler (October through March) and warmer (April through September) months. Statistical results are evaluated based on a significance level of 0.05 .

Water-quality data commonly are evaluated for two types of trends - monotonic trends (uniformly increasing or decreasing) and step trends. The method most often applied for evaluation of monotonic trends in water quality is the nonparametric seasonal Kendall trend test (Hirsch and others, 1982; Smith and others, 1982). This test compares observations from the same season of the year, thus reducing the effect of seasonal variations. The seasonal Kendall trend test is limited to 12 seasons or less per year for two reasons. The first reason is that potential statistical problems exist when water-quality values are so close in time that the values are not independent of one another. The second reason is that differences in water-quality conditions rarely exist between seasons shorter than 1 month (Schertz and others, 1991). Therefore, it is necessary to convert the daily concentrations and detections to appropriate monthly values. These values consist of monthly mean concentrations and monthly percentage of detections. The seasonal Kendall trend test is calculated using RUNSEAKEN, a program based on work by Hirsch and Slack (1984). This test requires a minimum of 60 months of data to calculate a trend. Stations used in this report had more than 72 months of data.

Stations and VOCs used for trend analysis were selected using two criteria. First, if less than 50 percent of the possible daily samples were collected in a month, then a missing value was recorded for the month. Second, if more than 50 percent of the months for the period of record had missing values, then trend analysis was not done on that VOC for that station because many missing values in the data set decrease the reliability of the trend analysis (Schertz and others, 1991). On the basis of the data-selection criteria, all of the stations and VOCs were selected for trend analysis except for benzene in samples from the Ohio River at East Liverpool, Ohio (station OR9408), because more than 50 percent of the months had missing values.
The null hypothesis for the seasonal Kendall trend test is that no trend in the data exists. The significance level of the trend test is determined by calculating a p-value, which is the probability of erroneously rejecting the null hypothesis. The null hypothesis is rejected if the p-value is less than or equal to $(\leq) 0.05$. The direction of trend is indicated by tau $(\tau)$, a single summary statistic for the period of record. Tau has a value between +1 and -1 . Positive values indicate increasing trends, negative values indicate decreasing trends, and values approaching zero indicate no trend. The seasonal Kendall slope estimator is an estimate of the magnitude of the slope of the trend. This statistic is computed by taking the difference of successive data values for a particular month and dividing by the period separating the data values to obtain the change per year due to the trend. The median of these slope estimates is the slope estimator. Using the median of the slope values reduces the effect of extreme values on the slope estimate. The slope estimator is unaffected by seasonality because the slopes are computed between the same seasons (Hirsch and others, 1982). The significance level of a trend is not affected by conventions of assigning concentrations to nondetections and unquantified detections; however, the slope of the trend could be affected. Time series of VOCs with a significant trend are plotted for selected stations.

\section{OCCURRENCE AND DISTRIBUTION OF VOLATILE ORGANIC COMPOUNDS}

\section{Basinwide Analysis}

A total of 44,837 river-water samples were collected at the 15 ORSANCO monitoring stations from 1987 through 1996. The number of samples collected among the stations was generally consistent with samples for 99 percent of the period of record. However, methylbenzene and ethylbenzene were reported only in samples collected from October 1 , 1991, to the end of the period of record. Therefore, the total number of samples for these two VOCs is about one-half that of other VOCs (table 3 at end of report). No VOCs were detected in 55 percent of the samples. One or more VOCs were detected in 45 percent of the samples, two to four VOCs were detected in 17 percent of the samples, and five or more VOCs were detected in less than 1 percent of the samples. Detections that 
were not quantified comprised less than 1 percent of all detections. The maximum number of VOCs detected in a sample was 11 (fig. 3). Descriptive statistics in table 3 were computed using only detected concentrations of VOCs; therefore, the statistics do not represent all concentrations because some low-level detections ( $\mathrm{M}$ remark code) were not quantified.

Each of the 21 target analytes were detected in 0.4 percent or more of the samples. Trichloromethane, detected in 26 percent of all samples, was the most frequently detected VOC in the Ohio River Basin (table 3, fig. 4). Following trichloromethane were benzene ( 11 percent), methylbenzene ( 6.4 percent), and the other 18 VOCs, which were detected in less than 4 percent of the samples (fig. 4A). When detected, most of the VOCs had median concentrations of 0.1 to $0.4 \mu \mathrm{g} / \mathrm{L}$ (fig. 4B). Detected concentrations of trichloromethane ranged from 0.05 to $125.3 \mu \mathrm{g} / \mathrm{L}$ with a median of $0.3 \mu \mathrm{g} / \mathrm{L}$. Detected concentrations of benzene ranged from 0.05 to $89 \mu \mathrm{g} / \mathrm{L}$ with a median of $0.1 \mu \mathrm{g} / \mathrm{L}$, and detected concentrations of methylbenzene ranged from 0.05 to $11.7 \mu \mathrm{g} / \mathrm{L}$ with a median of $0.1 \mu \mathrm{g} / \mathrm{L}$ (table 3 ). The refrigerant trichlorofluromethane, a chlorofluorocarbon (CFC), had the highest median detected concentration $(2.3 \mu \mathrm{g} / \mathrm{L})$. Other VOCs with high median detected concentrations were 1,2-dichloroethane (1.3 $\mu \mathrm{g} / \mathrm{L})$ and 1,1-dichloroethene $(0.4 \mu \mathrm{g} / \mathrm{L})$. Although these three VOCs had high median concentrations, they were detected in only 0.5 to 3.2 percent of the samples. The compound 1,2dichloroethane also was detected, at concentrations generally less than $0.8 \mu \mathrm{g} / \mathrm{L}$, in the lower Mississippi River from 1990 to 1992 (Barber and others, 1995).

To understand relations among VOCs, co-occurrences were calculated to determine which VOCs commonly occur together. Co-occurrence is the number of times a less frequently detected compound occurred with the more frequently detected compound (table 4 at end of report). For example, benzene (P34030) was detected 1,284 times with the 11,700 detections of trichloromethane (P32106). Thus, these two compounds had a percentage co-occurrence of 11 percent. The percentage co-occurrence among the 21 VOCs ranged from 0 to 23 percent. Compounds with greater than 20 percent co-occurrence were 1,2-dichlorobenzene and 1,3-dichlorobenzene; 1,2-dichlorobenzene and 1,4-dichlorobenzene; and the THMs dibromochloromethane and bromodichlo- romethane. The compound 1,2-dichlorobenzene is a solvent and fumigant and is used in chemical production (Pankow and Cherry, 1996). Ninety percent of 1,4-dichlorobenzene is used to produce insecticides or air deodorants, and 1,3-dichlorobenzene occurs as a byproduct during the production of 1,2-dichlorobenzene and 1,4-dichlorobenzene (Lucius and others, 1989).

Spearman rank-order correlations on detected concentrations also were calculated to understand relations among VOCs (table 5 at end of report). VOCs that are correlated strongly (Spearman correlation coefficient greater than 0.7) are chlorinated solvents (Pankow and Cherry, 1996) or THMs (Minear and Amy, 1995). The highest correlations were between trichloroethene and dibromochloromethane (0.82) and between bromodichloromethane and dibromochloromethane $(0.80)$. The strong relations between the brominated THMs could indicate that they are from chlorinated water. However, their concentrations are not correlated with trichloromethane, which could indicate multiple sources of THMs.

The detection of a VOC could be related to environmental factors, such as temperature, in addition to sources of VOCs to streams in the Ohio River Basin. Volatilization rates decrease with decreasing temperature, and, if the atmosphere is the source, VOC concentrations in water can increase by a factor of about 3 to 7 when temperatures decrease from 25 to $5^{\circ} \mathrm{C}$ (Lopes and Bender, 1998). The seasonal detection of some VOCs in urban stormwater possibly is due to this temperature dependence. Thus, a greater number of detections would occur during cooler months compared to warmer months if temperature is a significant factor. Average monthly air temperatures increase from the upstream to the middle and downstream parts of the Ohio River Basin (fig. 5A). However, seasonal temperature differences at a site are greater than the differences among sites. The seasonal detection of VOCs was examined by comparing the number of VOCs detected per sample and the percentage of detection of any VOC among months (fig. 5A,B); however, results indicate no seasonal differences. The median number of VOCs detected per sample is one in each month, and the percentage of detection of any VOC during the 12 months ranges from 43 to 50 percent compared to the overall detection of 45 percent. The same analysis using 


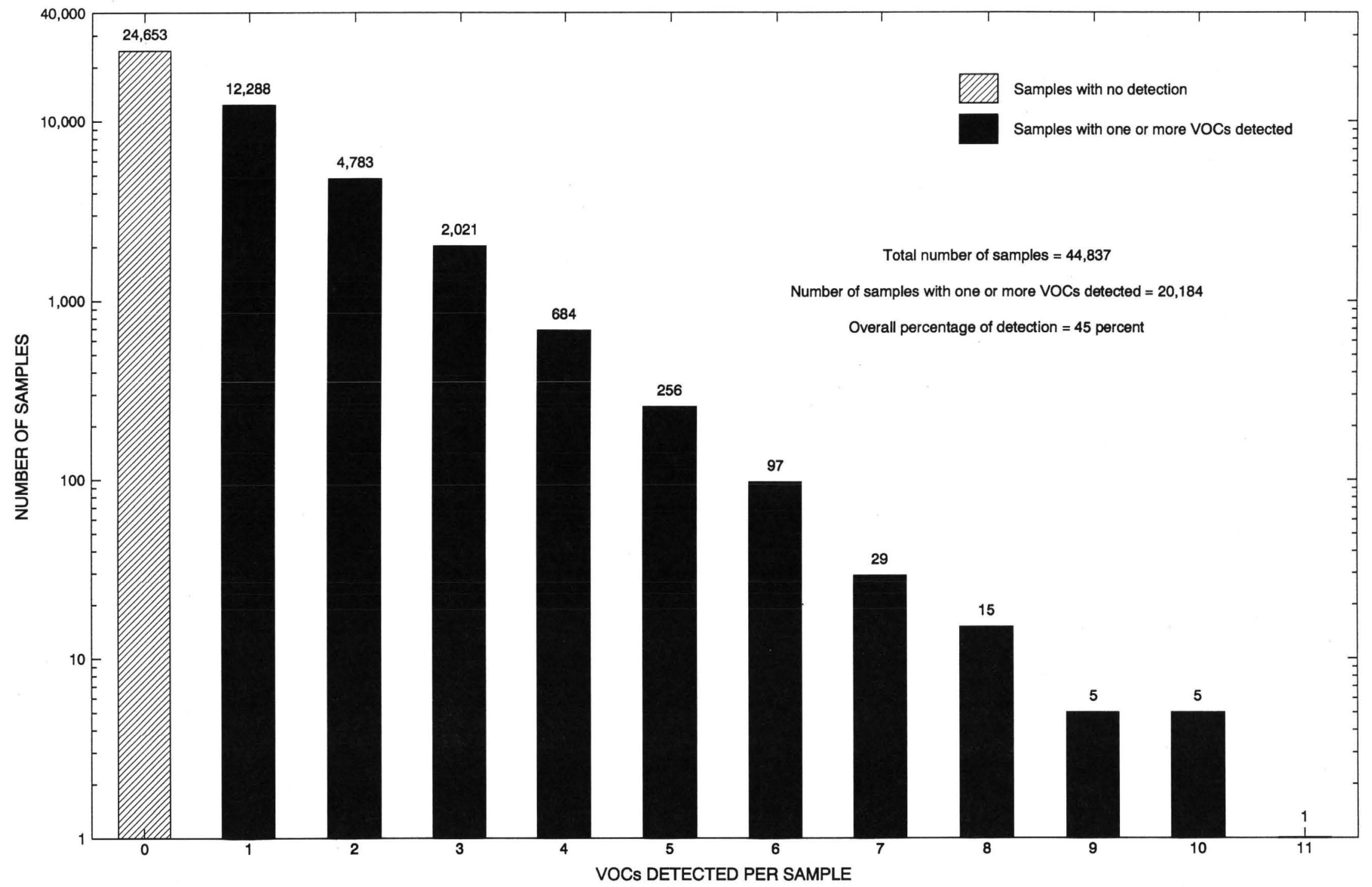

Figure 3. Number of volatile organic compounds (VOCs) detected in river-water samples from the Ohio River Basin, 1987-96. 

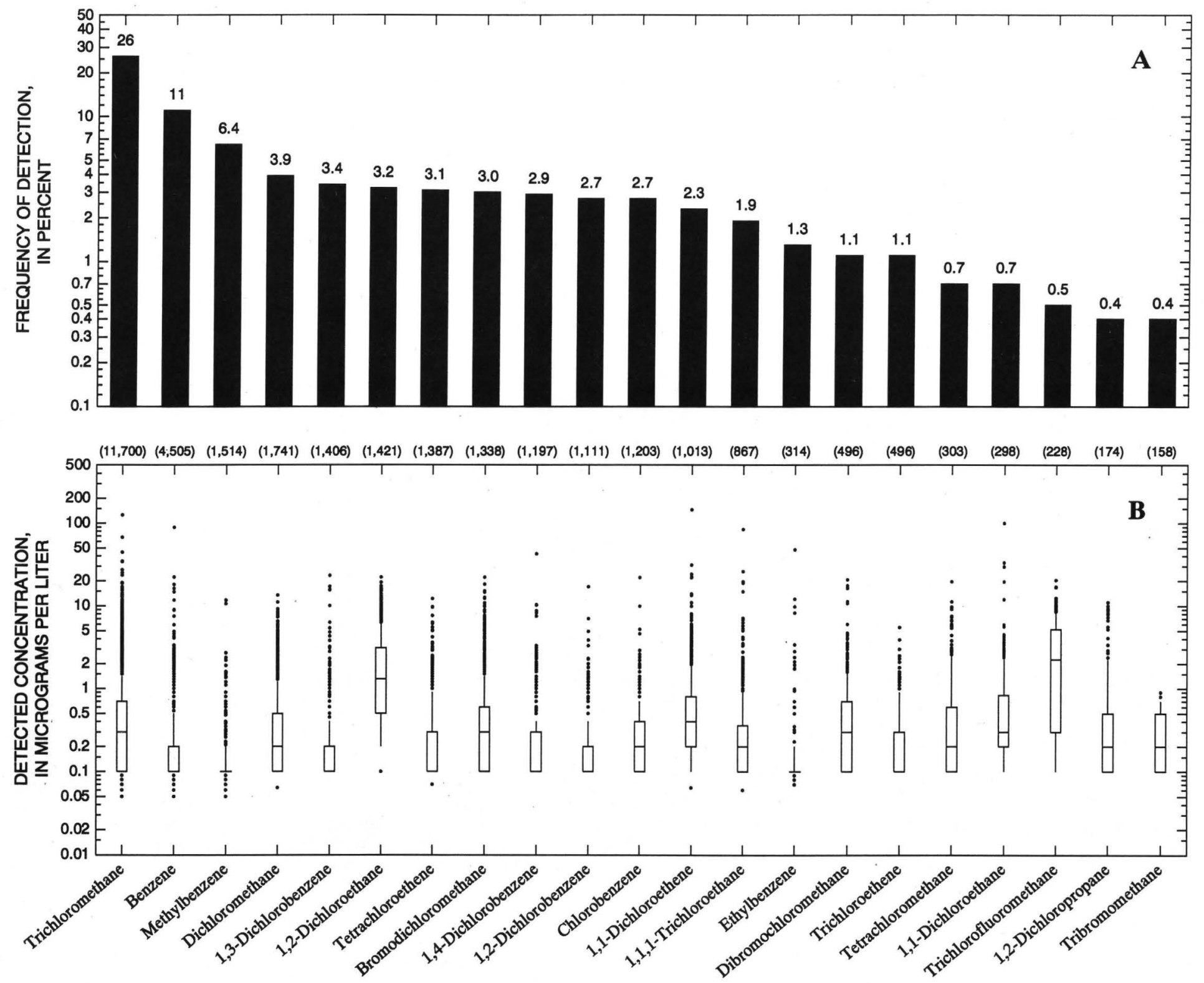

EXPLANATION

$(11,700)$ Number of detections

Data values outside the 10th and 90th percentiles

90th percentile

75th percentile

Median

25th percentile

10th percentile

Figure 4. (A) Frequencies of detection and (B) distribution of detected concentrations of volatile organic compounds (VOCs) in river-water samples from all monitoring stations sampled in the Ohio River Basin, 1987-96. 

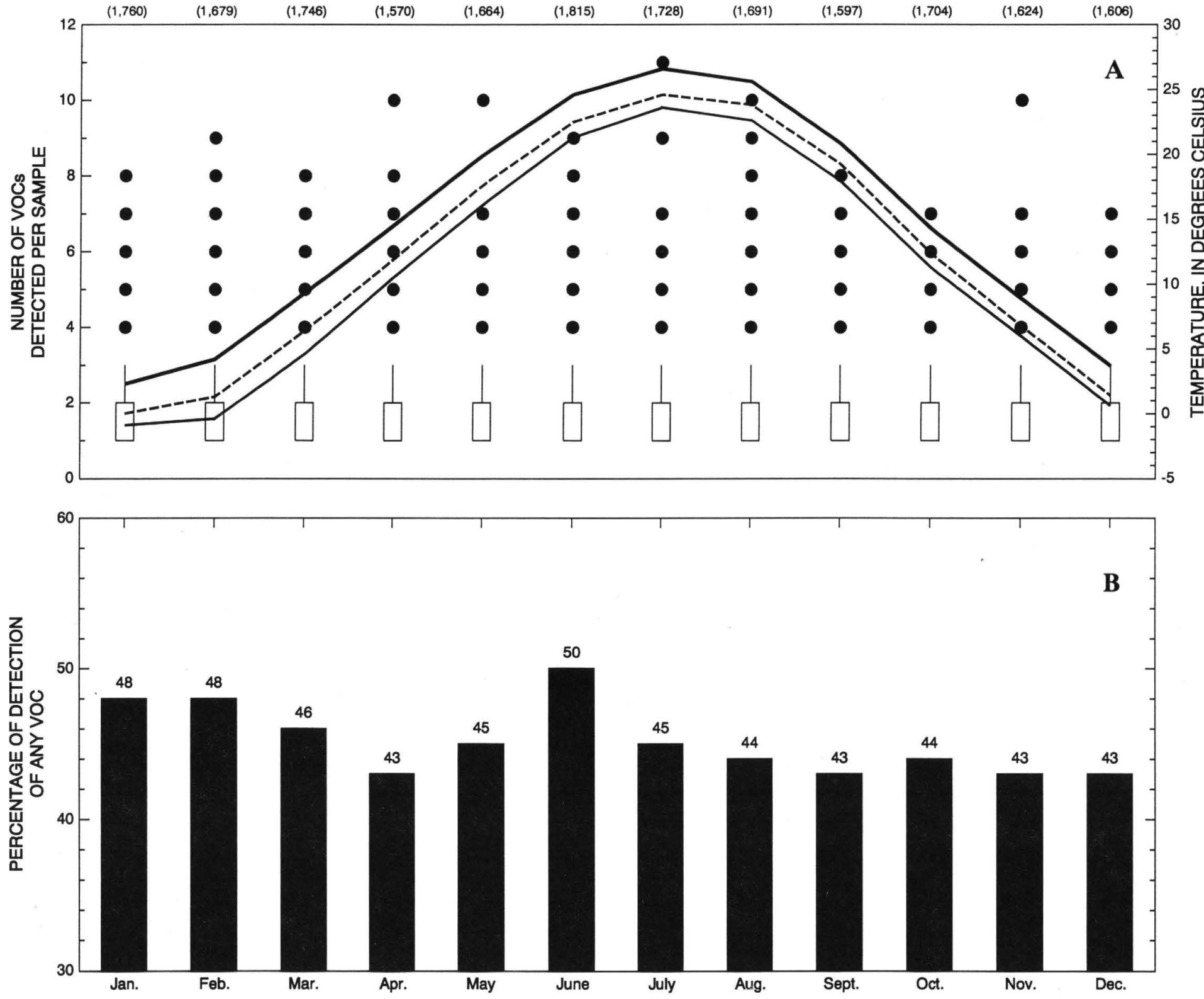

EXPLANATION

$(1,760)$ Number of samples with a detection

- Data values outside the 10th and 90th percentiles

90th percentile

75th percentile

Median

25th percentile

10th percentile

Average air temperature, Paducah, Ky

Average air temperature Cincinnati, Ohio

Average air temperature Pittsburgh, $\mathrm{Pa}$.

Figure 5. Seasonal distribution of volatile organic compounds (VOCs) per month by (A) number of VOCs detected per sample and (B) percentage of detection for all river-water samples from the Ohio River Basin, 1987-96. 
detected VOC concentrations had similar results, suggesting temperature has little effect on the occurrence of VOCs in river water of the Ohio River Basin.

The seasonal detection of each VOC also was evaluated by comparing the percentage of detection during cooler and warmer months (fig. 6). Rank-sum tests on all VOCs indicated that eight VOCs (table 6 at end of report) had statistically significant differences in detections between the cooler and warmer months. Benzene, methylbenzene, dichloromethane, and chlorobenzene occurred more frequently during cooler months. Bromodichloromethane, 1,2-dichloroethane, 1,1-dichloroethene, and trichlorofluoromethane occurred more frequently during warmer months. Slower volatilization rates or the increased partitioning from air into water during cooler months could cause the more frequent detection of benzene and methylbenzene. Lopes and Bender (1998) found that urban air could have been a source for benzene and methylbenzene in urban stormwater because most detections occurred in winter months and because water in equilibrium with urban air has similar concentrations. Higher detection frequencies during warmer months than during cooler months may be attributed to a decrease in stream discharge during warmer months when inputs of chlorinated water from ground-water sources, wastewater-treatment plants, swimming pools, and other outdoor uses of chlorinated water comprise a larger fraction of streamflow.

\section{Station-by-Station Analysis}

One or more VOCs were detected in 14 to 79 percent of the river-water samples from the individual ORSANCO monitoring stations (table 7 at end of report). Samples from six stations had one or more VOCs that were detected in 50 percent or more of the samples. The maximum number of VOCs detected in a sample was 11 from the Kanawha River at St. Albans, W. Va. (station KR38.3).

Trichloromethane was the most frequently detected VOC in samples from eight stations, benzene was the most frequently detected VOC in samples from four stations, and chlorobenzene, 1,3-dichlorobenzene, and 1,2-dichloroethane were the most frequently detected VOCs in samples from three stations (figs. 7-21). The percentage of detection of trichloromethane ranged from 0.1 to 72 percent and had no systematic spatial trend from upstream to downstream in the Ohio River Basin (fig. 22). High percentage detections of trichloromethane generally occurred in samples from stations that are downstream from large cities along the Ohio River. The percentage of detection of benzene ranged from 1 to 39 percent and high percentage detections occurred mostly in the upstream $40 \mathrm{mi}$ of the Ohio and Kanawha Rivers. Chlorobenzene was the most frequently detected VOC (20.3 percent) in samples from the Ohio River at Parkersburg, W. Va. (station OR790.7, fig. 14). In samples from the Ohio River at Weirton, W. Va. (station OR9159), 1,3-dichlorobenzene (7.8 percent), benzene (7.2 percent), and methylbenzene (6.3 percent) were detected at similar frequencies (fig. 12).

In samples from the Ohio River at Paducah, Ky. (station OR45.5), 1,2-dichloroethane was the most frequently detected VOC (56 percent) with a median detected concentration of $1.5 \mu \mathrm{g} / \mathrm{L}$ (fig. 21). This VOC, a suspected carcinogen, is associated with the production of rubber tires, insecticides, and gasoline and has been a long-term concern in the Paducah area (Ohio River Valley Water Sanitation Commission, 1994). Samples from the Paducah station accounted for 1,312 of the 1,421 (92 percent) detections of 1,2-dichloroethane in the Ohio River Basin. Most detections occurred from 1987 through 1993, with the annual median detected concentration decreasing from 2.7 to $0.3 \mu \mathrm{g} / \mathrm{L}$. Some detections exceeded the USEPA MCL for drinking water of $5.0 \mu \mathrm{g} / \mathrm{L}$ (Verschueren, 1983). Detections of 1,2-dichloroethane have occurred since 1993, although concentrations have not exceeded the MCL in recent years. The source of the 1,2dichloroethane has been determined to be contaminated ground water at an industrial site on a major tributary of the Ohio River (Tennant and others, 1992).

The median detected concentration for most of the VOCs was $0.1 \mu \mathrm{g} / \mathrm{L}$ in samples from all stations (table 8 at end of report). In general, samples from stations in the upstream part of the Ohio River Basin that is between Pittsburgh, Pa., and Portsmouth, Ohio, and samples from the Kanawha River had the highest sum of detected concentrations (fig. 23). Samples 


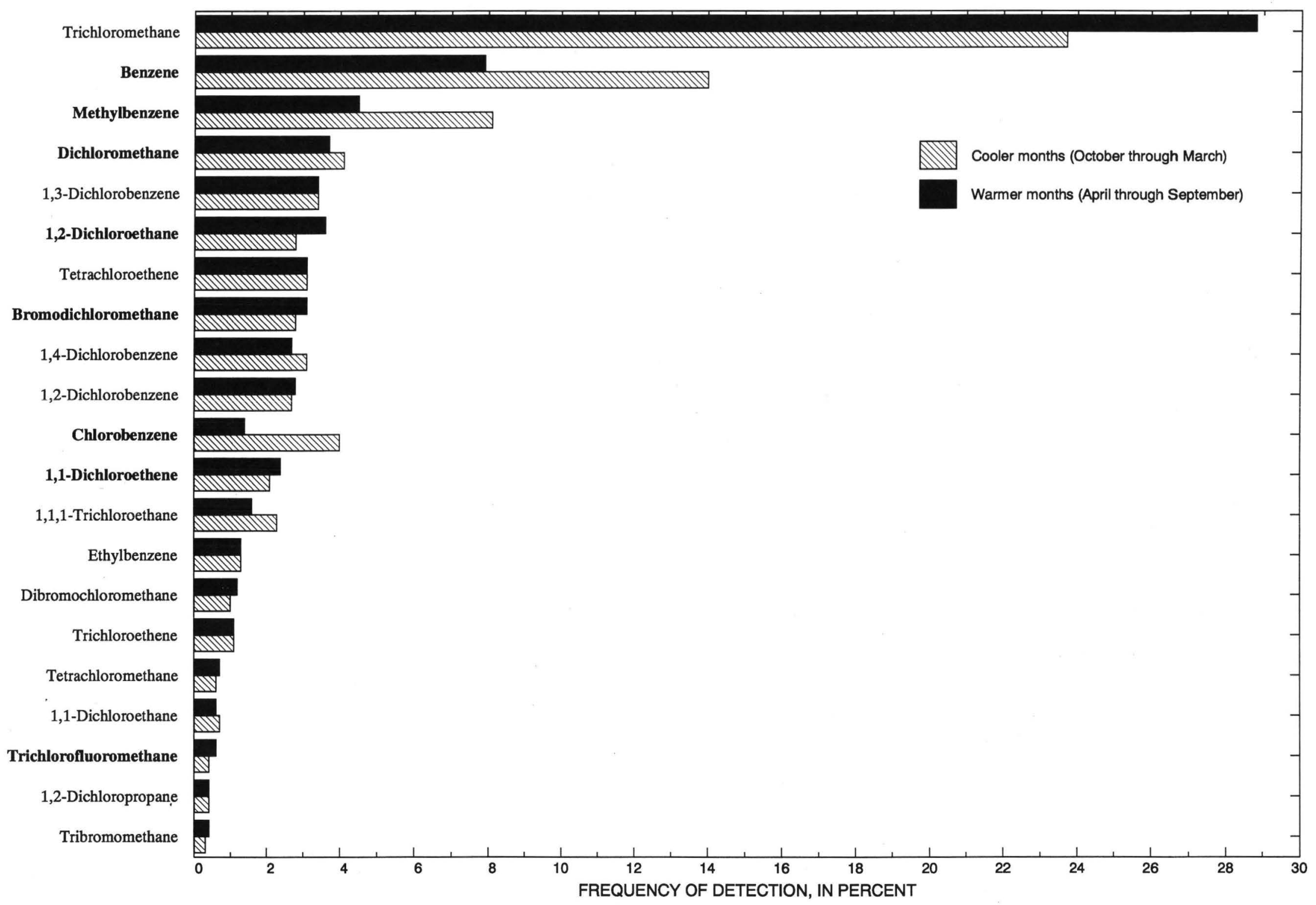

Figure 6. Frequency of detection of volatile organic compounds (VOCs) during cooler and warmer months, Ohio River Basin, 1987-96. Compound names in bold indicate VOCs with significantly different percentage of detection between cooler and warmer months. 

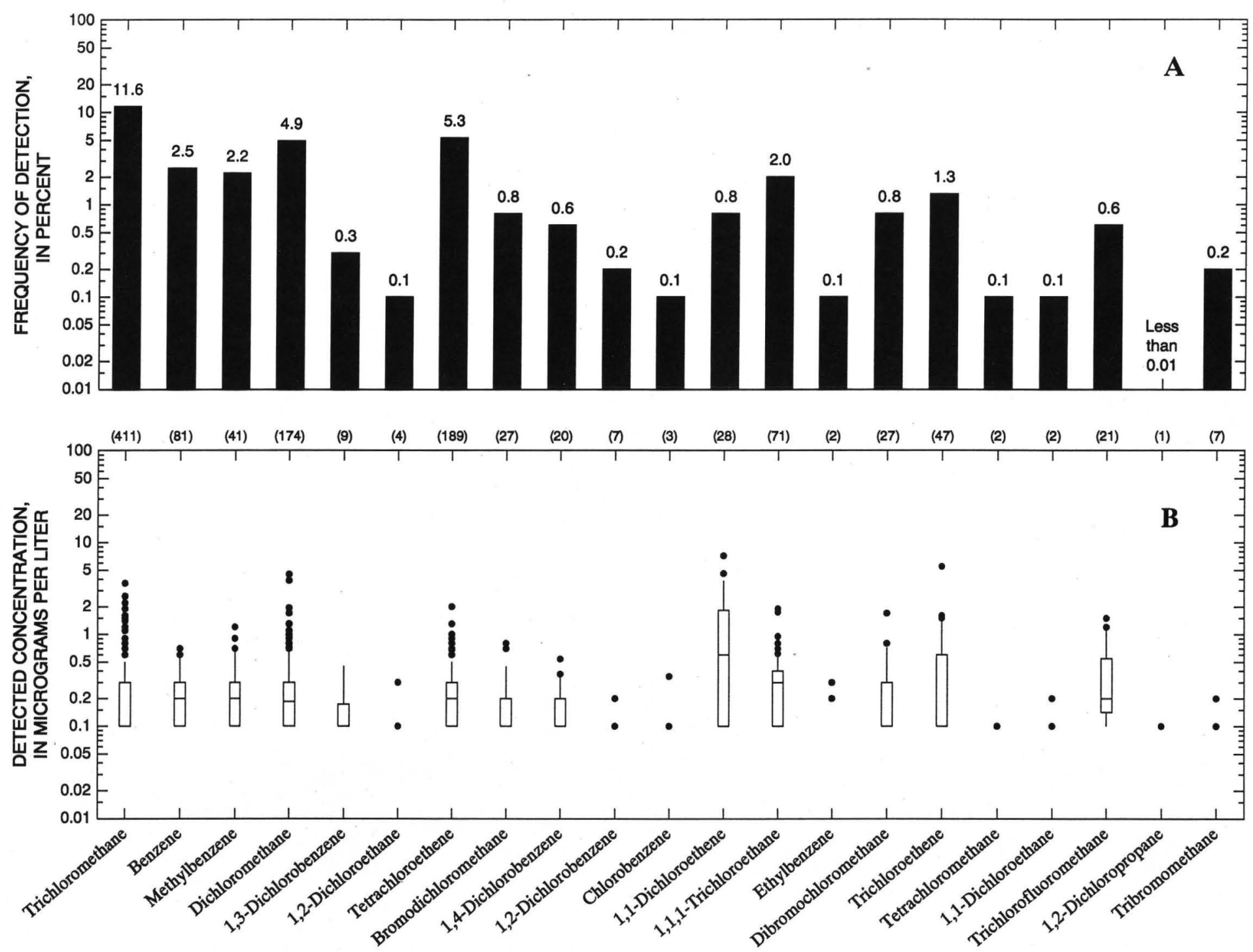

EXPLANATION

(411) Number of detections

- Data values outside the 10th and 90th percentiles

90th percentile

75th percentile

Median

25 th percentile

10th percentile

Flgure 7. (A) Frequencies of detection and (B) distribution of detected concentrations of volatile organic compounds (VOCs) in river-water samples from the Allegheny River at Pittsburgh, Pa. (station AR7.40), Ohio River Basin, 1987-96. 

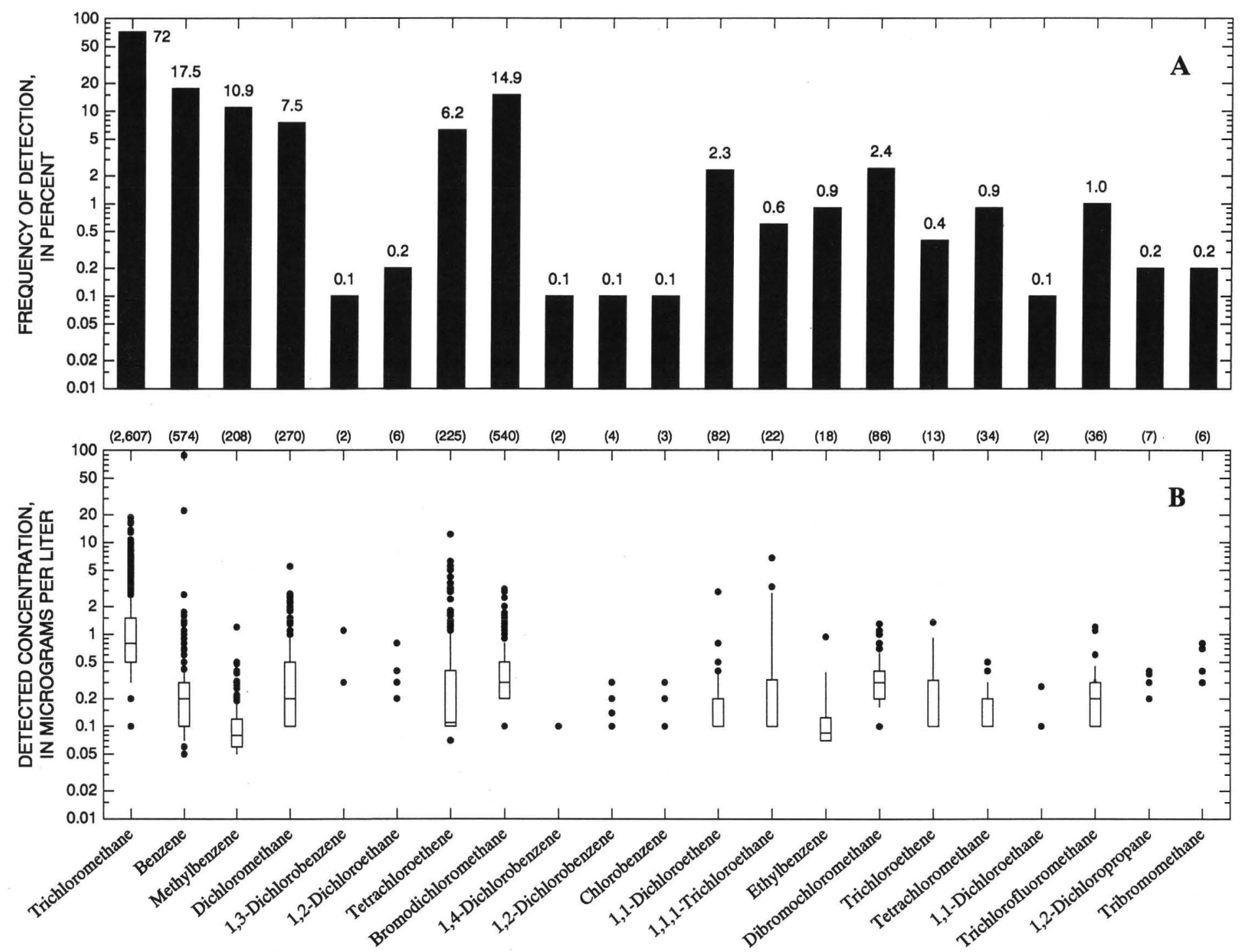

EXPLANATION

$(2,607)$ Number of detections

- Data values outside the 10th and 90th percentiles

90th percentile

75th percentile

Median

25th percentile

10th percentile

Figure 8. (A) Frequencies of detection and (B) distribution of detected concentrations of volatile organic compounds (VOCs) in river-water samples from the Monogahela 

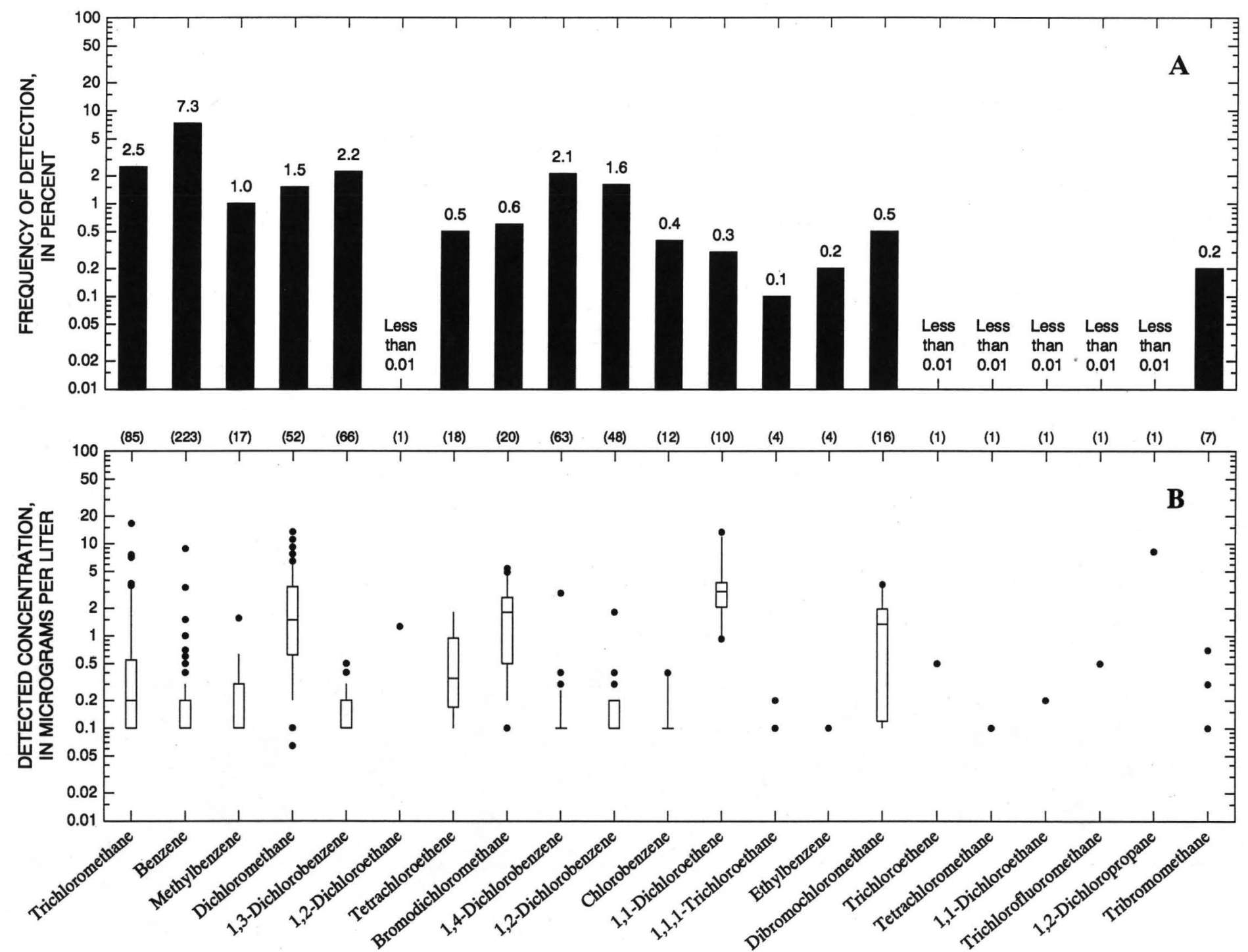

EXPLANATION

(85) Number of detections

- Data values outside the 10th and 90th percentiles

90th percentile

75th percentile

Median

25th percentile

10th percentile

Flgure 9. (A) Frequencies of detection and (B) distribution of detected concentrations of volatile organic compounds (VOCs) in river-water samples from the Ohio River at Neville Island, Pa. (station OR976.50), Ohio River Basin, 1987-96. 

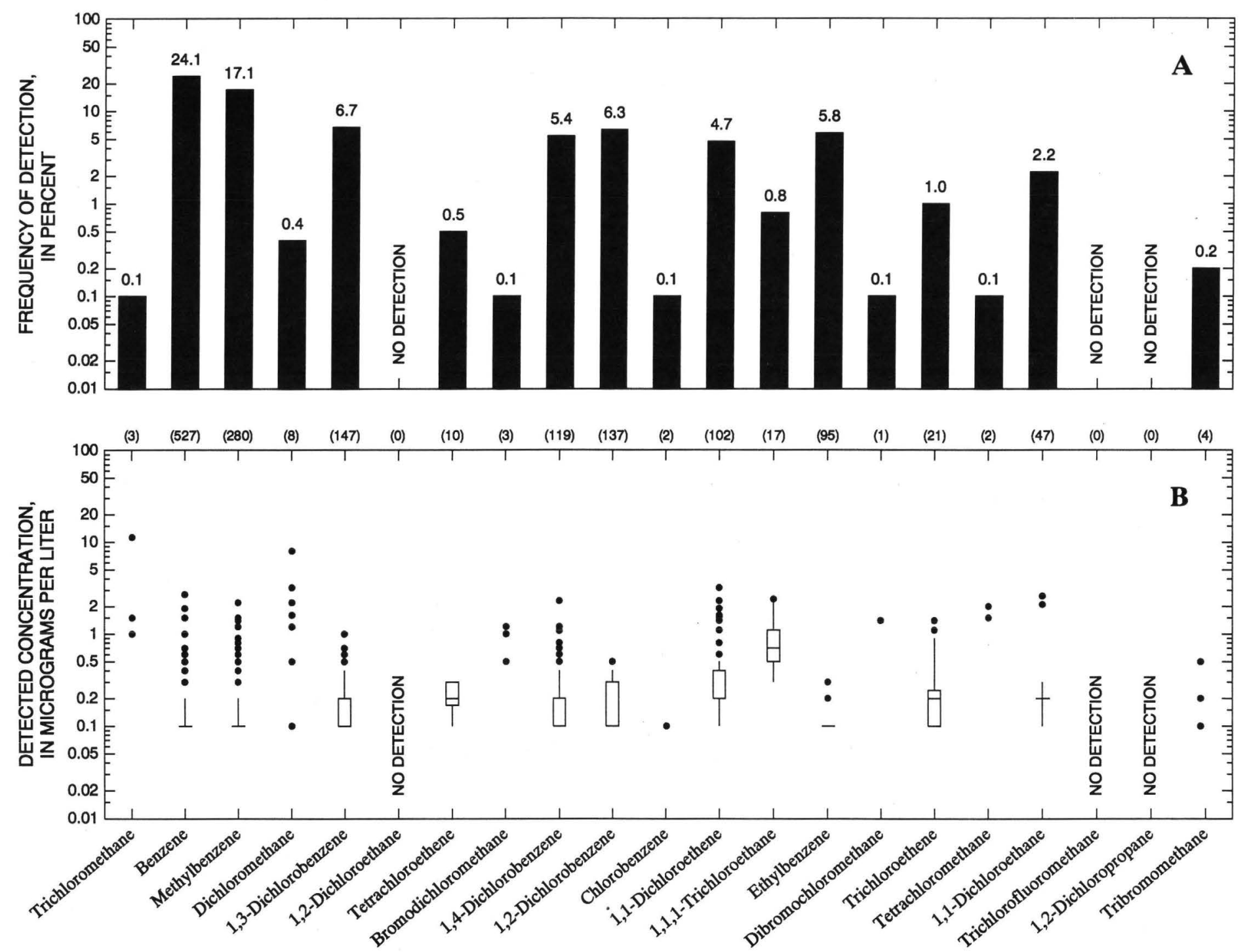

EXPLANATION

(3) Number of detections

- Data values outside the 10th and 90th percentiles

90th percentile

75th percentile Median

25th percentile

10th percentile

Figure 10. (A) Frequencies of detection and (B) distribution of detected concentrations of volatile organic compounds (VOCs) in river-water samples from the Ohio River at Shippingport, Pa. (station OR946.1), Ohio River Basin, 1987-96. 

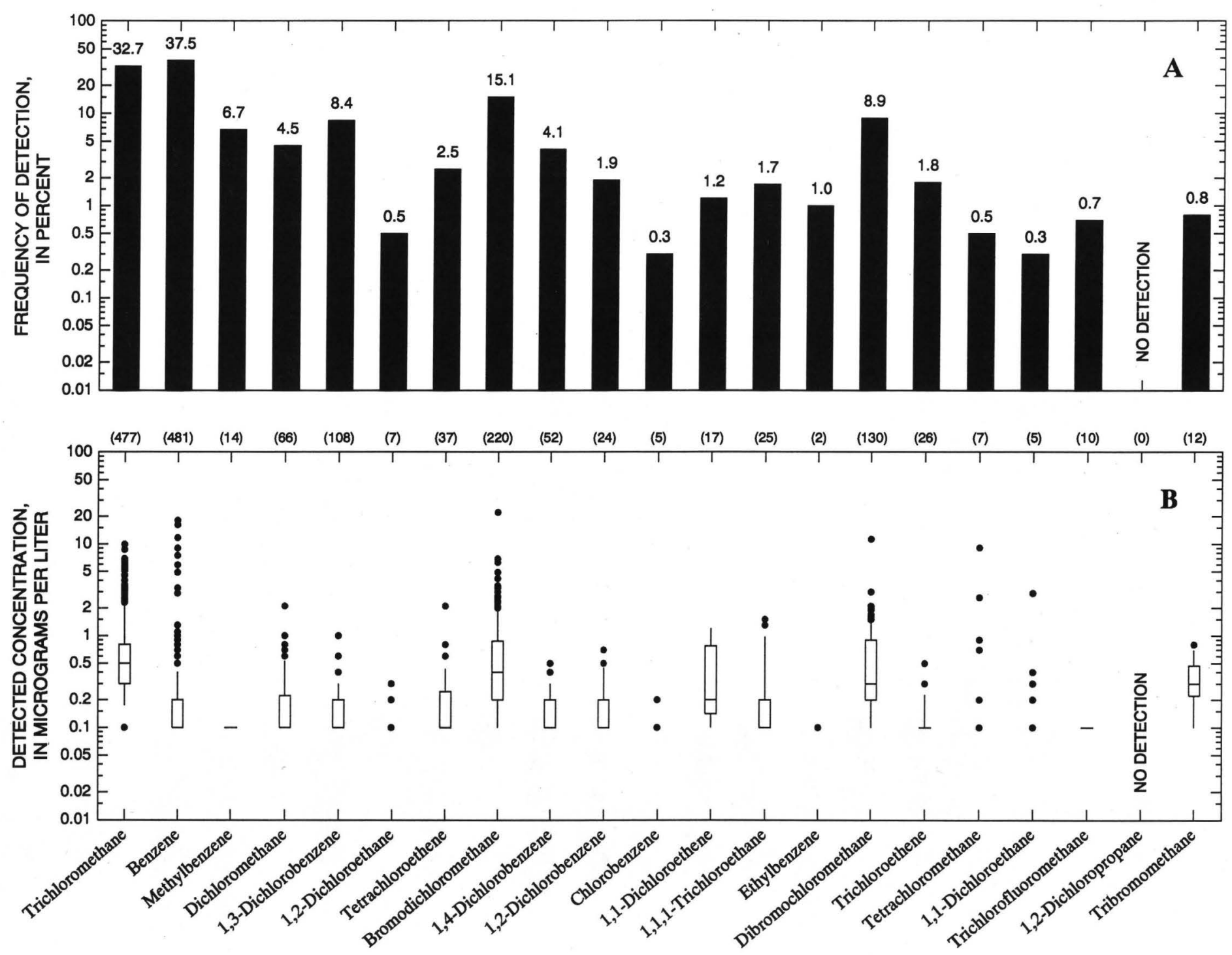

EXPLANATION

(477) Number of detections

- Data values outside the 10th and 90th percentiles

90th percentile

75th percentile

Median

25th percentile

10th percentile

Figure 11. (A) Frequencies of detection and (B) distribution of detected concentrations of volatile organic compounds (VOCs) in river-water samples from the Ohio River at East Liverpool, Ohio (station OR9408), Ohio River Basin, 1987-96. 

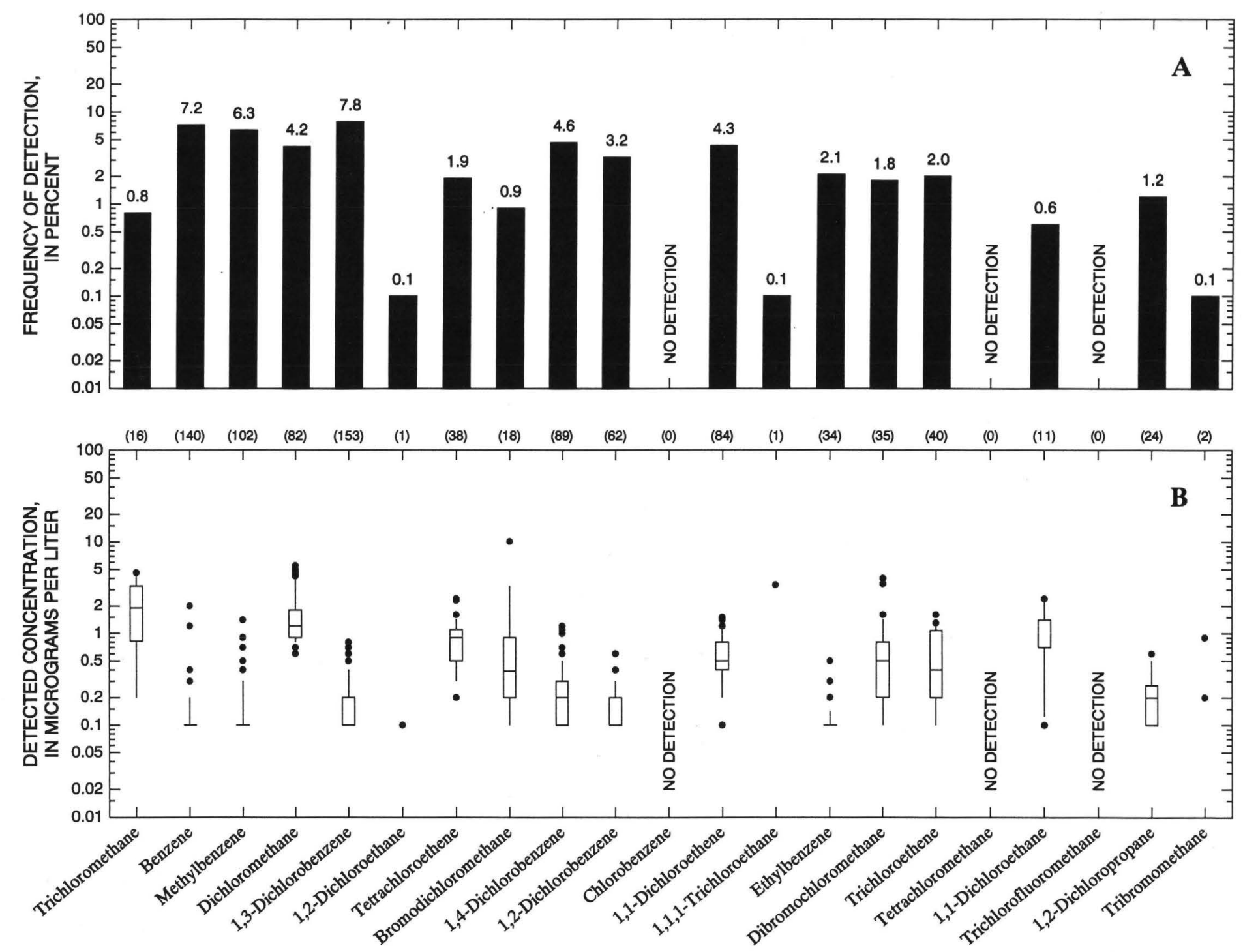

EXPLANATION

(16) Number of detections

- Data values outside the 10th and 90th percentiles

90th percentile

75th percentile

Median

25th percentile

10th percentile

Figure 12. (A) Frequencies of detection and (B) distribution of detected concentrations of volatile organic compounds (VOCs) in river-water samples from the Ohio River at Weirton, W. Va. (station OR9159), Ohio River Basin, 1987-96. 

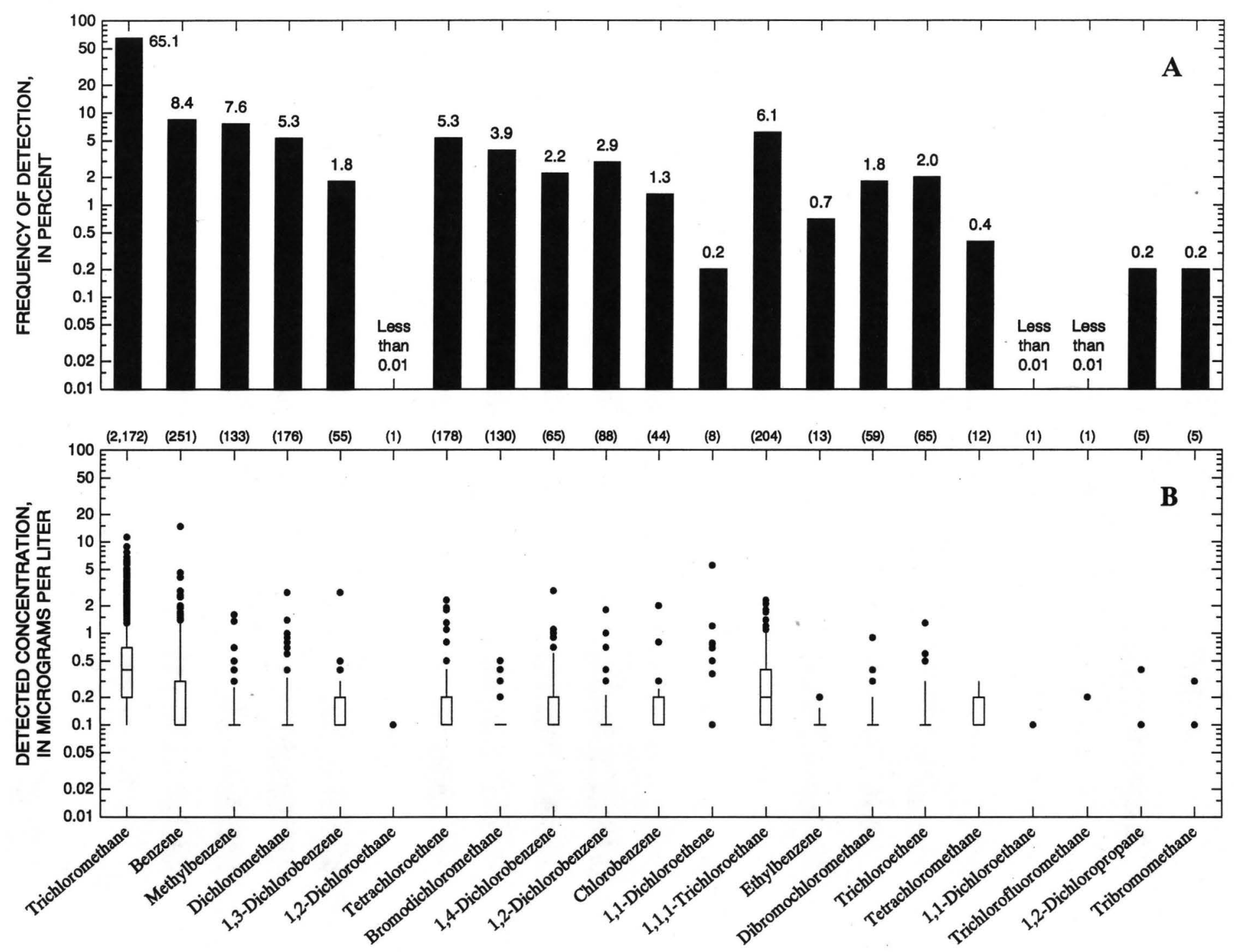

EXPLANATION

(5) Number of detections

- Data values outside the 10th and 90th percentiles

90th percentile

75th percentile

Median

25th percentile

10th percentile

Figure 13. (A) Frequencies of detection and (B) distribution of detected concentrations of volatile organic compounds (VOCs) in river-water samples from the Ohio River at Wheeling, W. Va. (station OR894.2), Ohio River Basin, 1987-96. 

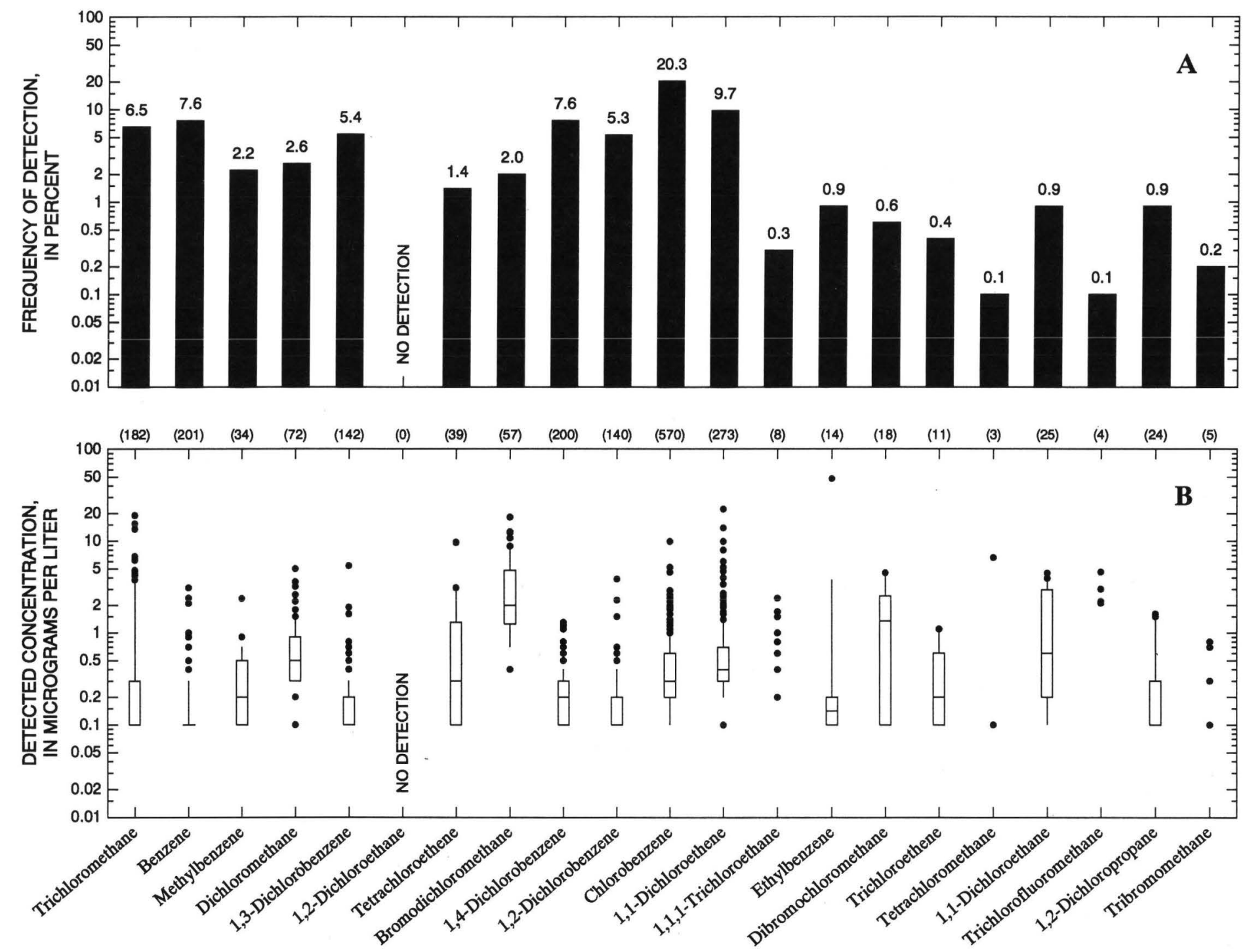

EXPLANATION

(182) Number of detections

- Data values outside the 10th and 90th percentiles

90th percentile

75th percentile

Median

25th percentile

10th percentile

Figure 14. (A) Frequencies of detection and (B) distribution of detected concentrations of volatile organic compounds (VOCs) in river-water samples from the Ohio River at Parkersburg, W. Va. (station OR790.7), Ohio River Basin, 1987-96. 

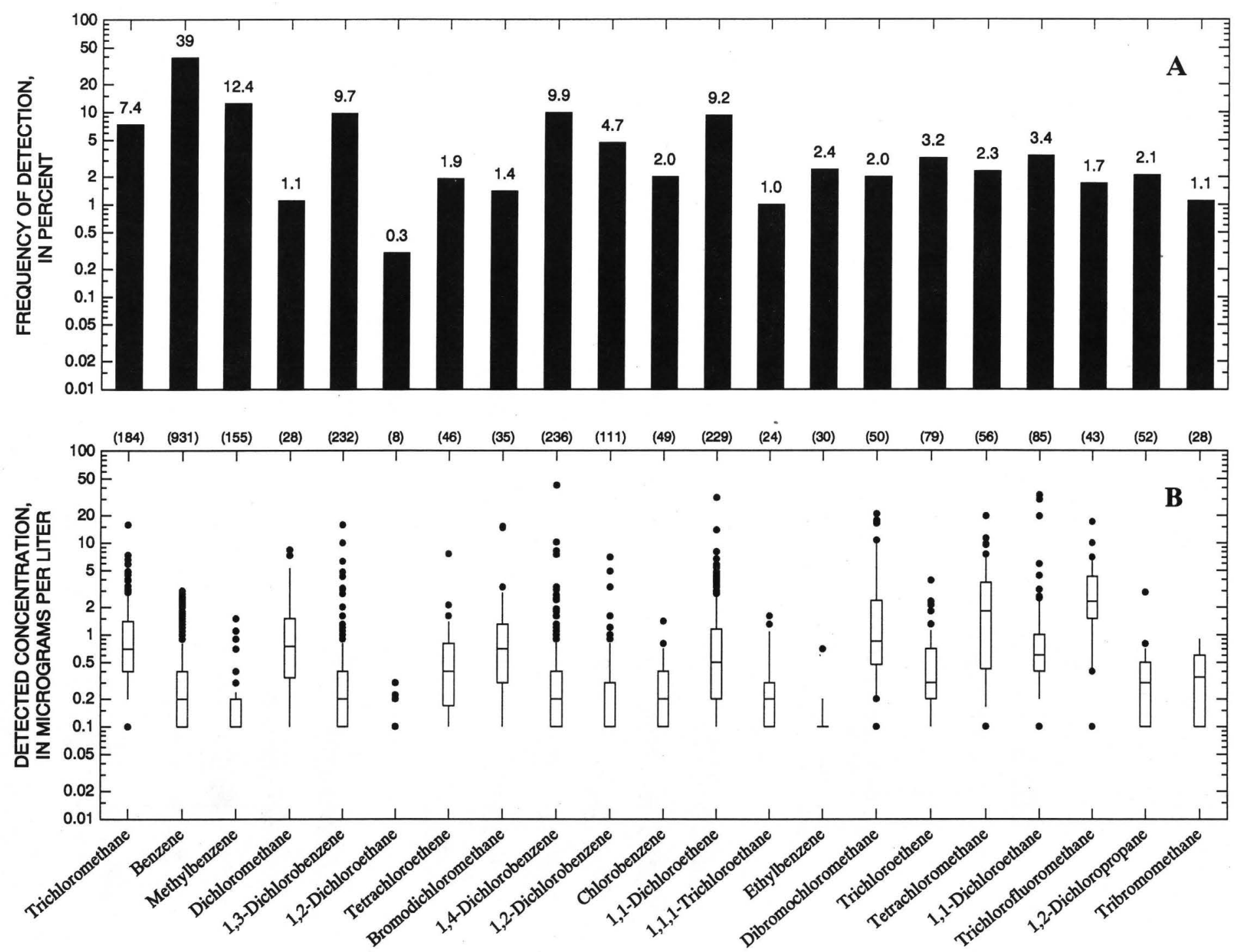

EXPLANATION

(184) Number of detections

- Data values outside the 10th and 90th percentiles

90th percentile

75th percentile

Median

25th percentile

10th percentile

Figure 15. (A) Frequencies of detection and (B) distribution of detected concentrations of volatile organic compounds (VOCs) in river-water samples from the Kanawha River at St. Albans, W. Va. (station KR38.3), Ohio River Basin, 1987-96. 

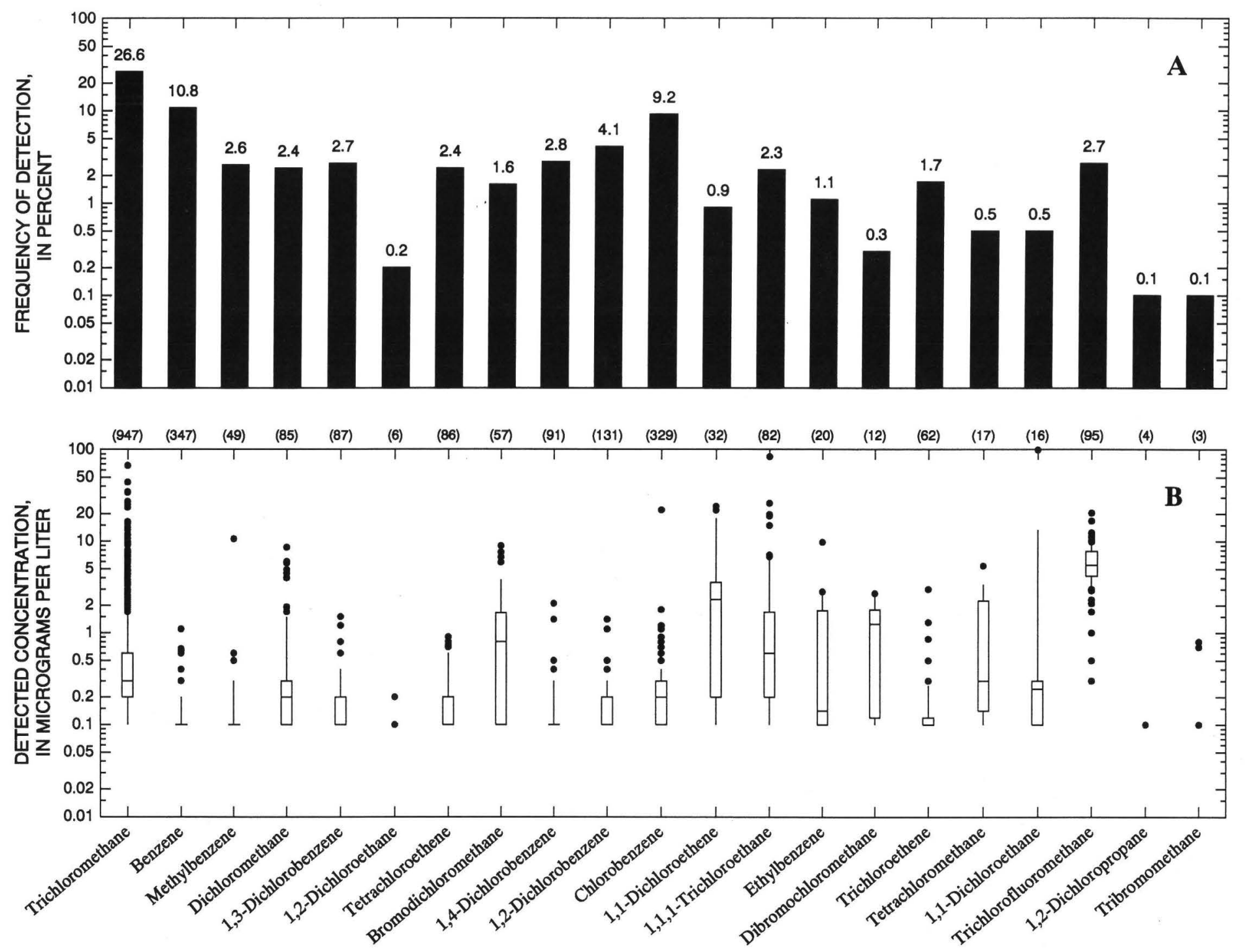

\section{EXPLANATION}

(947) Number of detections

- Data values outside the 10th and 90th percentiles

90th percentile

75th percentile

Median

25th percentile

10th percentile

Figure 16. (A) Frequencies of detection and (B) distribution of detected concentrations of organic compounds (VOCs) in river-water samples from the Ohio River at 

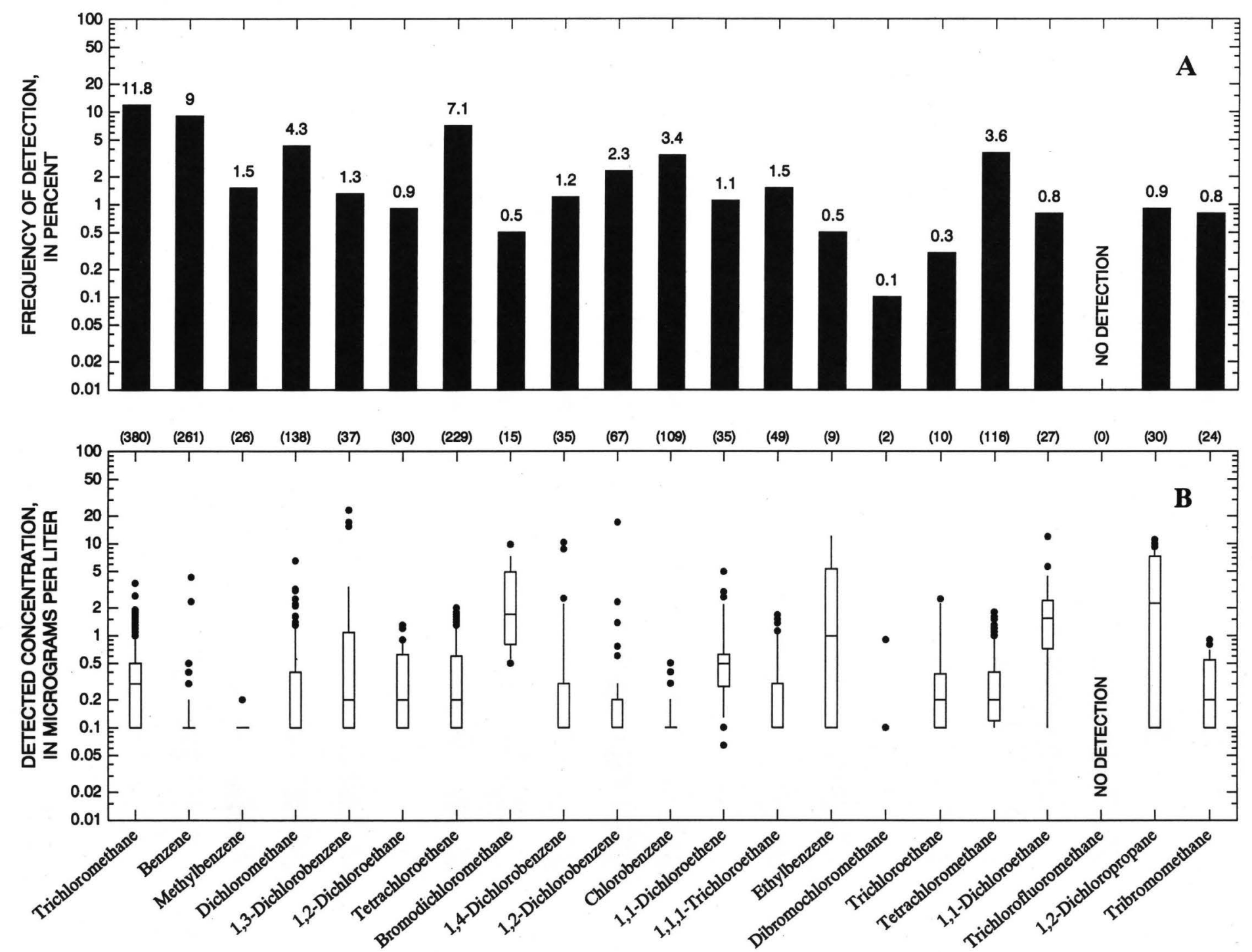

\section{EXPLANATION}

(380) Number of detections

- Data values outside the 10th and 90th percentiles 90th percentile 75th percentile Median 25th percentile 10th percentile

Figure 17. (A) Frequencies of detection and (B) distribution of detected concentrations of volatile organic compounds (VOCs) in river-water samples from the Ohio River at Portsmouth, Ohio (station OR630.9), Ohio River Basin, 1987-96. 

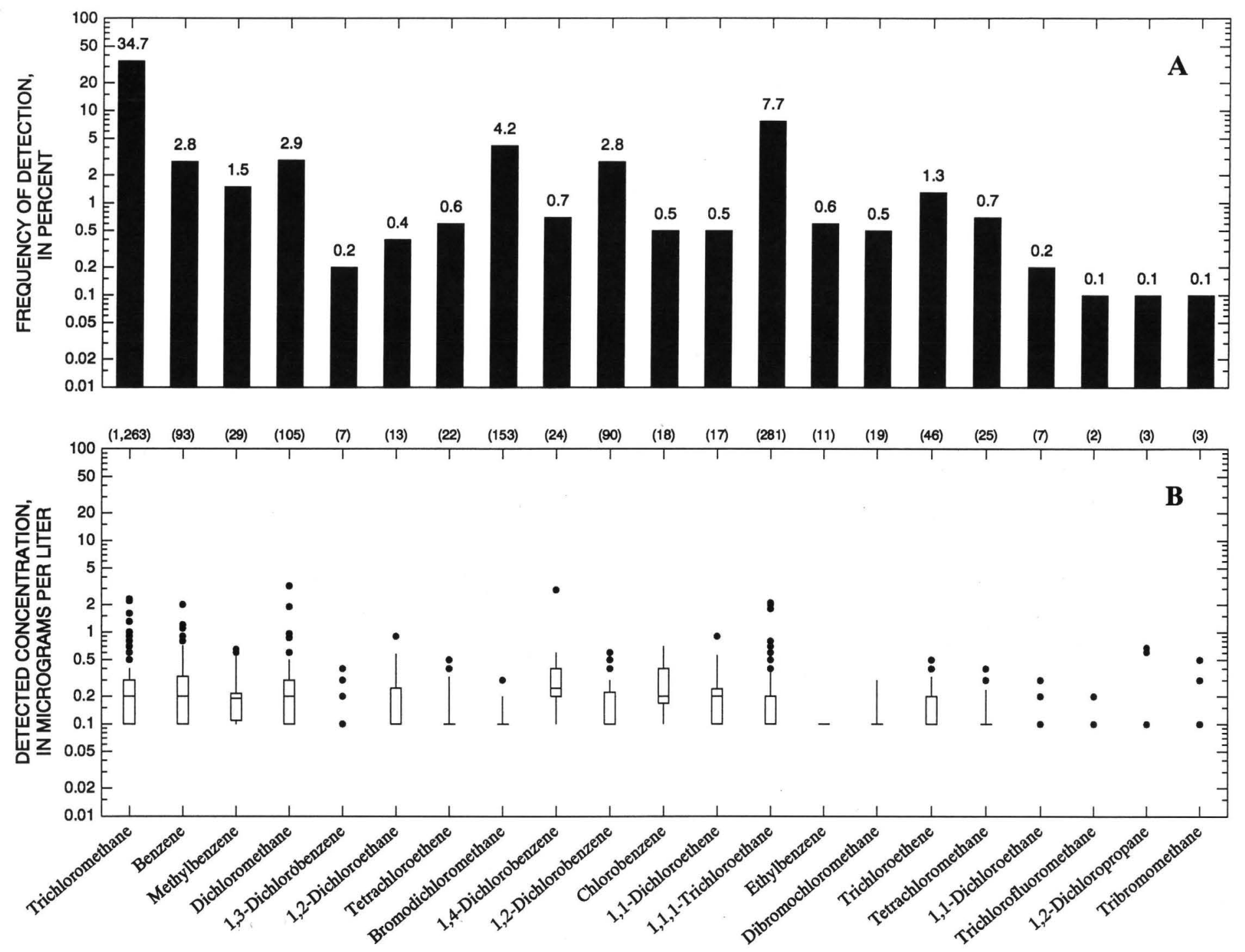

EXPLANATION

(3) Number of detections

- Data values outside the 10th and 90th percentiles 90th percentile 75 th percentile Median 25th percentile 10th percentile

Figure 18. (A) Frequencies of detection and (B) distribution of detected concentrations of volatile organic compounds (VOCs) in river-water samples from the Ohio River at Cincinnati, Ohio (station OR518.2), Ohio River Basin, 1987-96. 

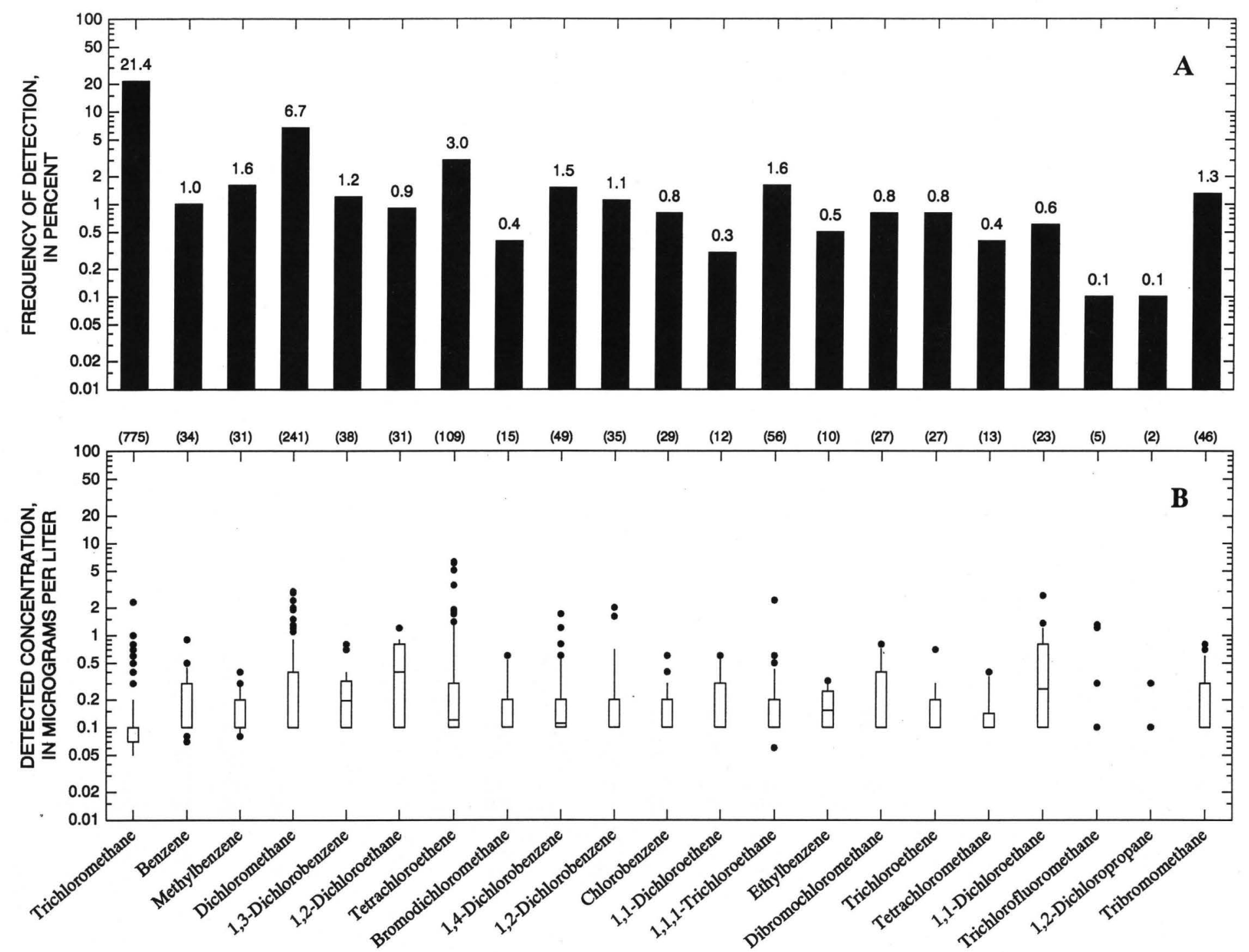

EXPLANATION

(46) Number of detections

- Data values outside the 10th and 90th percentiles 90th percentile 75th percentile Median 25th percentile 10th percentile

Figure 19. (A) Frequencies of detection and (B) distribution of detected concentrations of volatile organic compounds (VOCs) in river-water samples from the Ohio River at Louisville, Ky. (station OR380.4), Ohio River Basin, 1987-96. 

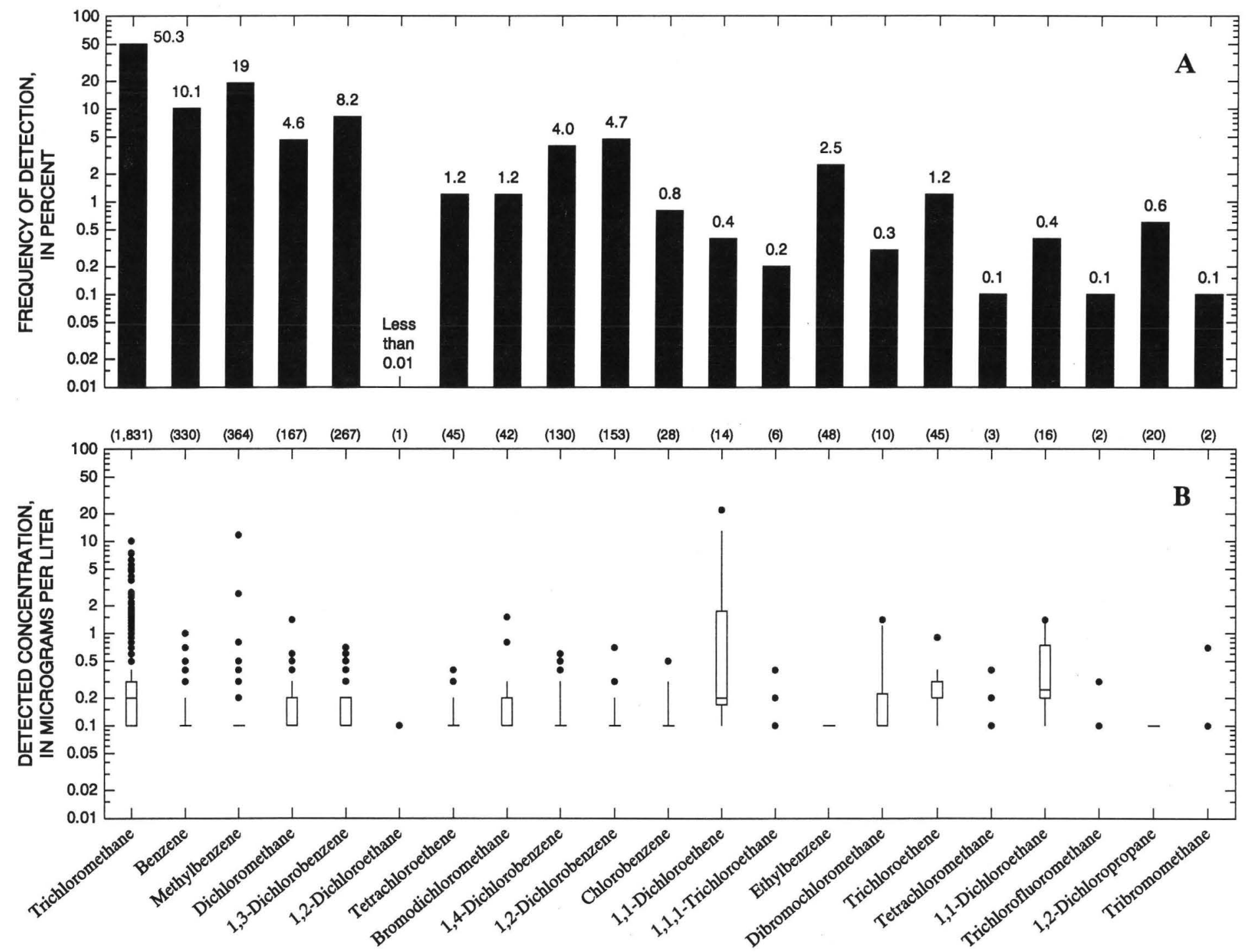

EXPLANATION

(2) Number of detections

- Data values outside the 10th and 90th percentiles

90th percentile

75th percentile

Median

25th percentile

10th percentile

Figure 20. (A) Frequencies of detection and (B) distribution of detected concentrations of volatile organic compounds (VOCs) in river-water samples from the Ohio River at Evansville, Ind. (station OR189.5), Ohio River Basin, 1987-96. 

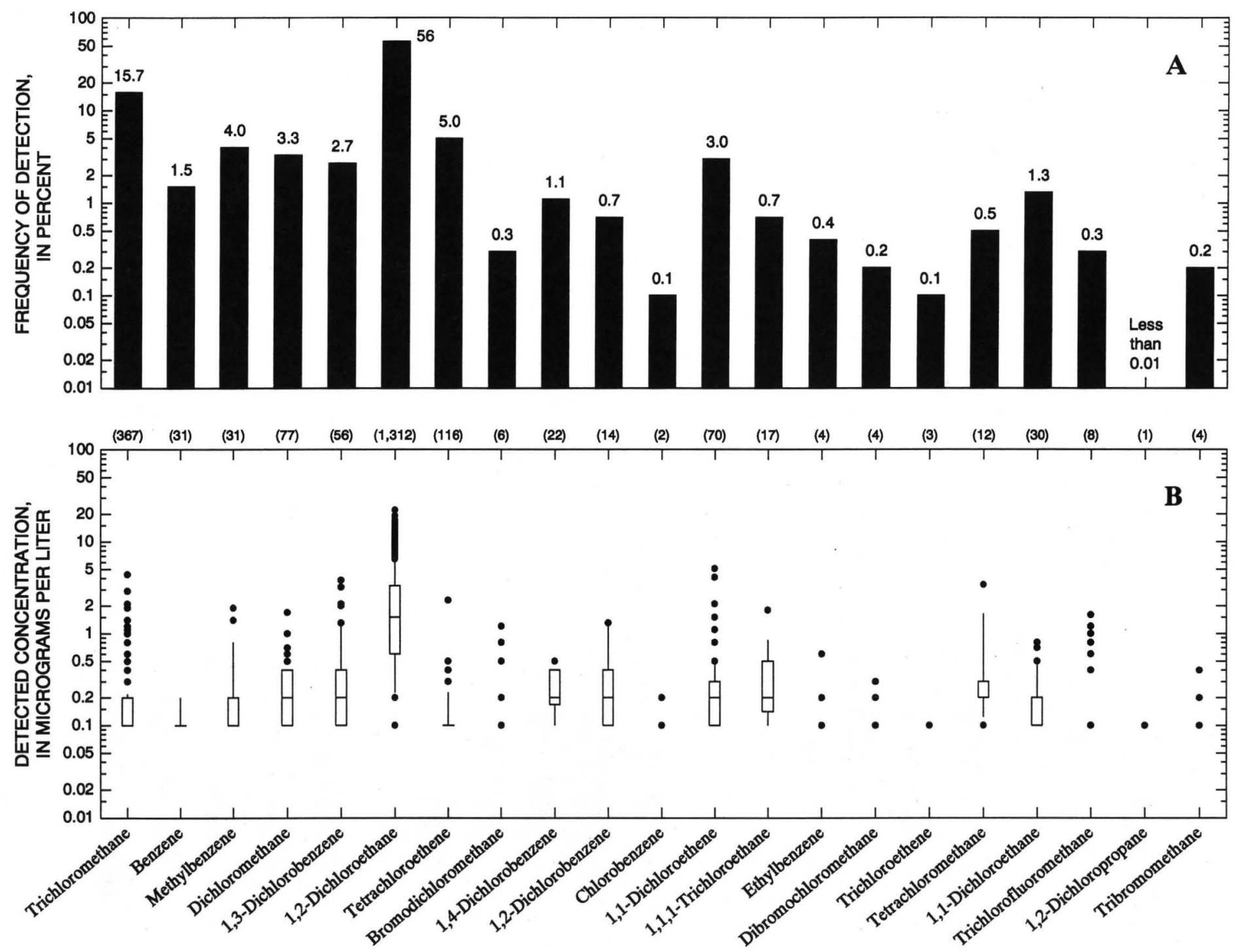

EXPLANATION

(367) Number of detections

- Data values outside the 10th and 90th percentiles

90th percentile

75th percentile

Median

25th percentile

10th percentile

Flgure 21. (A) Frequencies of detection and (B) distribution of detected concentrations of volatile organic compounds (VOCs) in river-water samples from the Ohio River at Paducah, Ky. (station OR45.5), Ohio River Basin, 1987-96. 

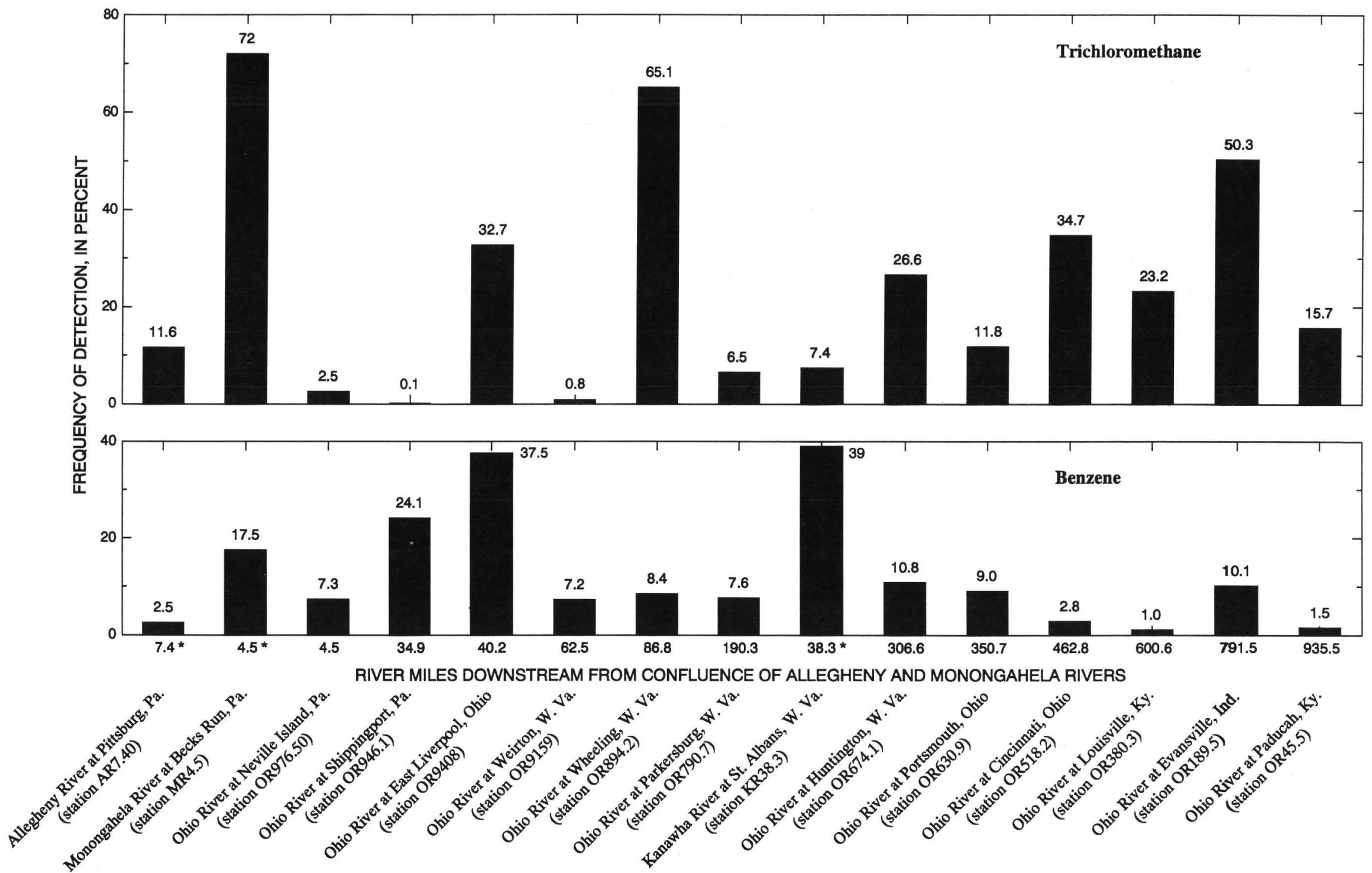

Figure 22. Frequencies of detection of trichloromethane and benzene in river-water samples from the Ohio River Valley Water Sanitation Commission (ORSANCO) monitoring stations, Ohio River Basin, 1987-96. Asterisk (*) indicates a tributary stream to the Ohio River. 


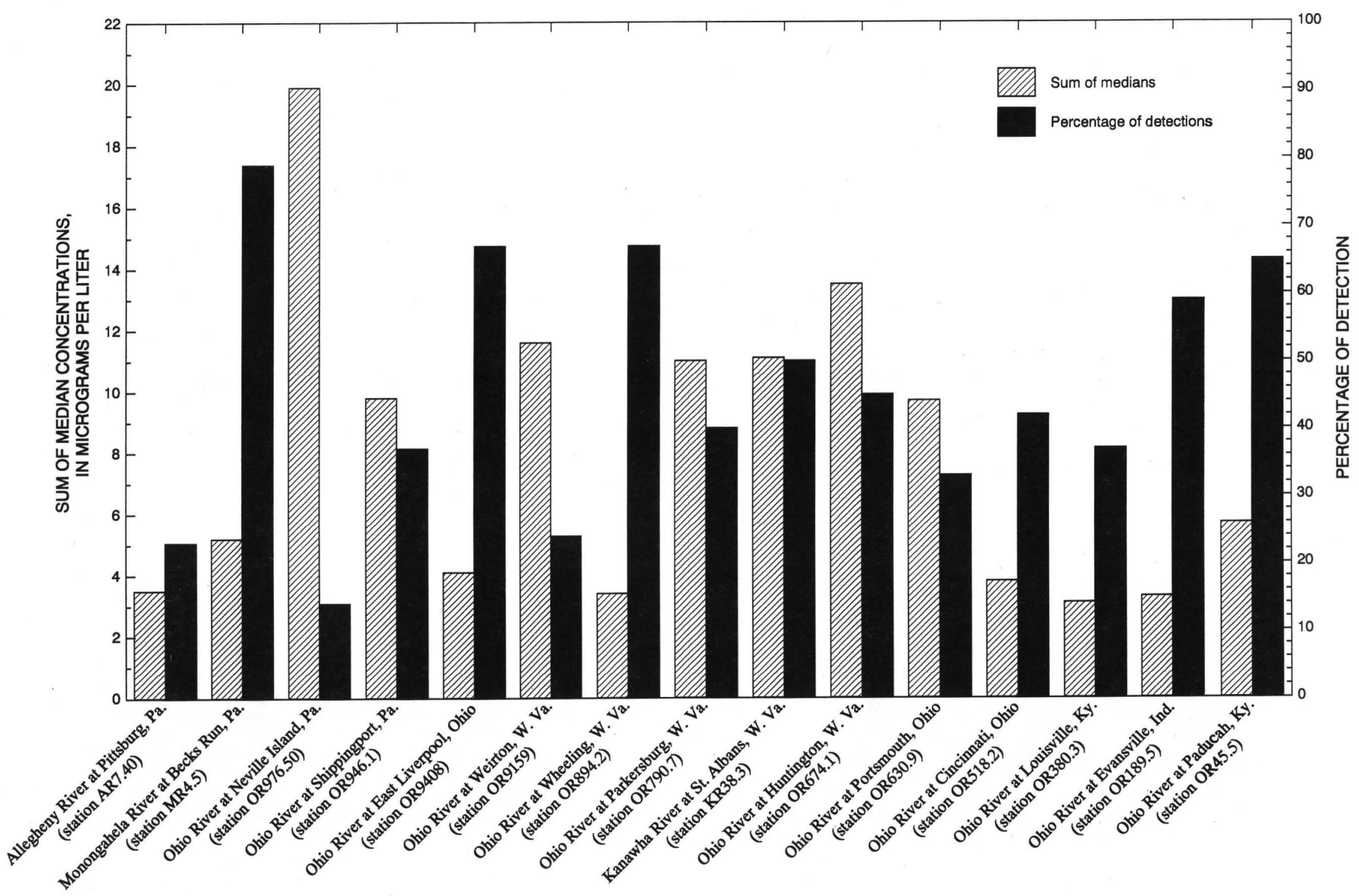

Figure 23. Sum of the median concentrations and percentage of detection of any of one or more volatile organic compounds (VOCs) in river-water samples from the Ohio River Valley Water Sanitation Commission (ORSANCO) monitoring stations, Ohio River Basin, 1987-96. Location of river-water samples monitoring stations shown in figure 1. 
from some stations had high sums of detected concentrations, but the VOCs were infrequently detected.

This is an artifact of analyzing only detected concentrations rather than all data including values less than the MDL.

The highest median detected concentration was 1,2-dichloropropane in samples from the Ohio River at Neville Island, Pa. (station OR976.50), with a median of $8.2 \mu \mathrm{g} / \mathrm{L}$; however, this was the only detection in 3,419 samples. The maximum detected concentrations of 1,1-dichloroethene $(145.4 \mu \mathrm{g} / \mathrm{L})$ and trichloromethane $(125.3 \mu \mathrm{g} / \mathrm{L})$ occurred in samples from the Ohio River at Huntington, W. Va. (station OR674.1), on the same day. Upstream industries along the Ohio River between Huntington and the confluence of the Kanawha River are possible sources. Industries on the Kanawha River also are possible sources; however, high VOC concentrations were not detected for the previous few days in samples from upstream stations on the Kanawha River or the Ohio River.

Co-occurrence of VOCs was calculated for samples from the individual stations (table 9 at end of report). The percentage of co-occurrence between compounds ranged from 0 to 100 percent. However, many of the high percentages are for VOCs that had few detections. Samples from the Ohio River at Paducah, Ky. (station OR45.5), had three of the highest percentage co-occurrences; for example, 82 percent (63 of 77) of 1,2-dichloroethane detections occurred with dichloromethane. The percentage of cooccurrences between dibromochloromethane and bromodichloromethane, both THMs, was high at six stations and in the basinwide analysis (table 4). The highest co-occurrence of these THMs (67 percent) was in samples from the Ohio River at Weirton, W. Va. (station OR9159), and co-occurrence ranged between 40 and 55 percent in samples from the other five stations. Seven stations had high percentage cooccurrences between 1,2-dichlorobenzene and 1,3dichlorobenzene ( 24 to 50 percent), and eight stations had high percentage co-occurrences between 1,2dichlorobenzene and 1,4-dichlorobenzene (23 to 50 percent). These co-occurrences also are similar to the basinwide analysis (table 4).

Significant Spearman rank correlations between detected concentrations of THMs and between gasoline-related compounds (benzene, methylbenzene, and ethylbenzene) occurred mostly in samples from the upstream part of the Ohio River Basin (table 10 at end of report, fig. 24). Most correlations between THMs were greater than 0.6 , and most correlations between gasoline-related compounds were between 0.4 and 0.6 . These correlations could be due to urbanization and associated wastewater discharges. Most of the significant correlations were between solvents, and the greatest number of correlations between solvents occurred in samples from the Kanawha River and the two stations on the Ohio River that straddle the confluence of the Ohio and Kanawha Rivers. Upstream from the confluence, trichloromethane is correlated mostly with other THMs. On the Kanawha River and downstream from the confluence, trichloromethane is correlated mostly with chlorinated solvents and not with THMs. Benzene is correlated with chlorinated solvents more than gasoline-related compounds in samples from throughout the Ohio River Basin. This could suggest that industrial uses of chloroform and benzene, not chlorinated water or petroleum products, are the predominant sources. The multiple sources of trichloromethane likely explain why it did not correlate with other THMs in the basinwide analysis (table 5). Eight pairs of VOCs had negative correlations that ranged from -0.47 to -0.90 . It is unknown why these VOCs are inversely correlated.

The seasonal variability in the number of detected VOCs also was evaluated for samples from individual stations. No distinct seasonal differences were observed in the median number of VOCs detected in samples from most stations. However, samples from two stations (Ohio River at Shippingport, Pa., station OR946.1, and Ohio River at Wheeling, W. Va., station OR894.2) showed a seasonal pattern with more VOCs detected during cooler months compared to warmer months (fig. 25). The lack of seasonal differences in the number of VOCs detected in samples from most stations again suggests that temperature has little effect on VOCs in the Ohio River Basin.

\section{Comparison to Drinking-Water Regulations}

Because the Ohio River is used for public water supplies, it is important to compare detected concentrations of VOCs to drinking-water regulations to measure the status of the water quality (table 11 at end of report). The USEPA has established an MCL 


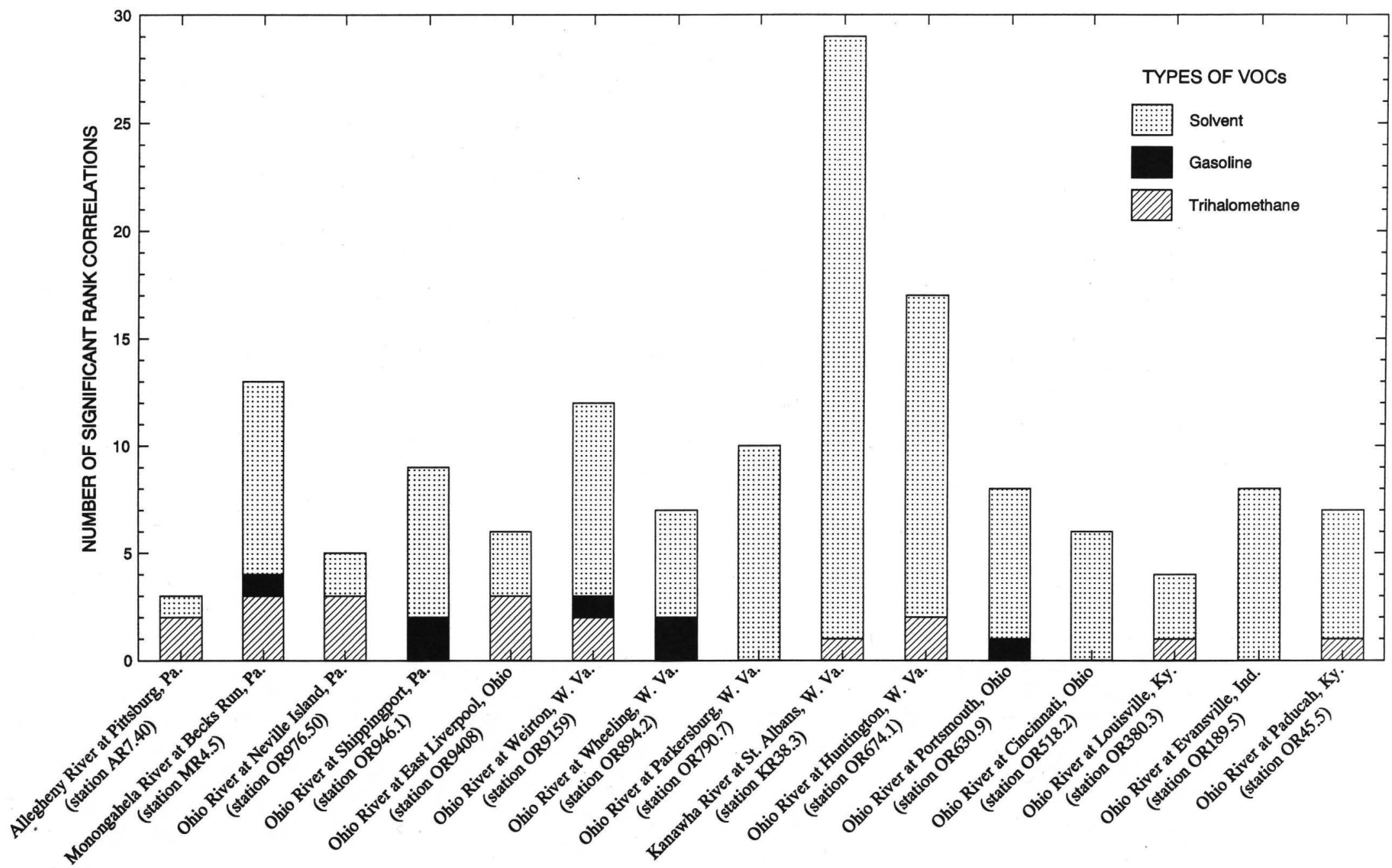

Flgure 24. Number of significant rank correlations between detectable concentrations of volatile organic compounds (VOCs) in river-water samples from individual Ohio River Valley Water Sanitation Commission (ORSANCO) monitoring stations, Ohio River Basin, 1987-96. 


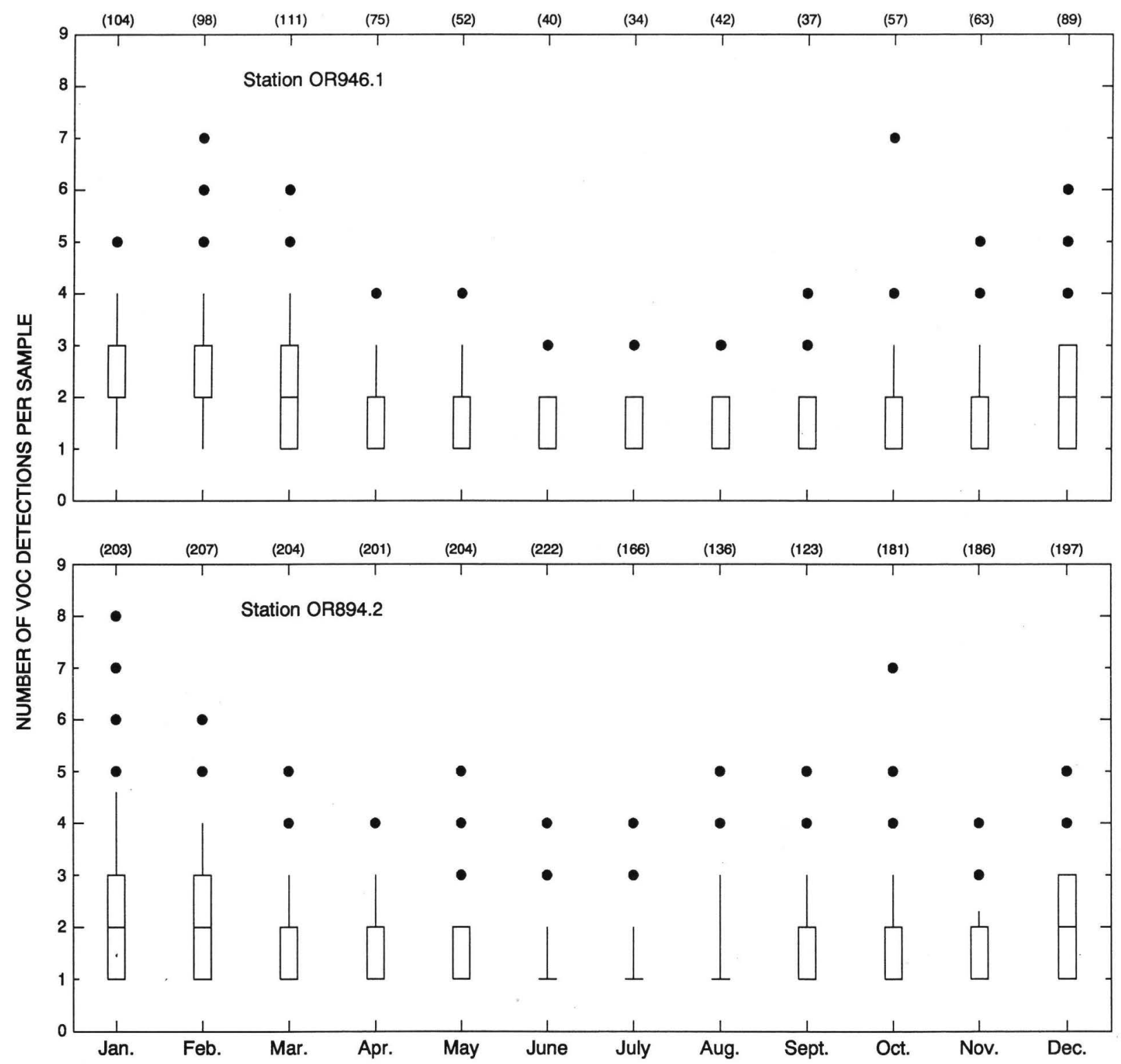

EXPLANATION

(89) Number of detections

- Data values outside the 10th and 90th percentiles

90th percentile

75th percentile

Median

25th percentile

10th percentile

Figure 25. Seasonal distribution of number of volatile organic compounds (VOCs) detected per month in river-water samples from the Ohio River at Shippingport, Pa. (station OR946.1), and at Wheeling, W. Va. (station OR894.2), 1987-96. 
in drinking water for 18 of the 21 VOCs (U.S. Environmental Protection Agency, 1994, 1996). The THMs trichloromethane, bromodichloromethane, dibromochloromethane, and tribromomethane are regulated on the basis of the sum of the concentration of these four compounds. A drinking-water regulation is a legally enforceable requirement that includes an MCL, for the protection of human health, that public water supplies should not exceed (Ammore and Hautala, 1983; Verschueren, 1983).

More than 99 percent of the raw-water samples contained VOC concentrations within USEPA drinking-water regulations. At least one MCL was exceeded in 268 ( 0.6 percent) of 44,837 river-water samples (table 11). Most exceedances were of 1,2-dichloroethane in samples from an ORSANCO monitoring station on the Ohio River at Paducah, Ky. (station OR45.5). This compound accounted for 188 of the 268 exceedances, and the remaining exceedances generally occurred in samples from the upstream part of the Ohio River Basin and the Kanawha River. Exceedances of 1,2-dichloroethane were due to contaminated ground water (Tennant and others, 1992) and occurred during the first 6 years of this study as follows: 1987 (62 exceedances), 1988 (72 exceedances), 1989 (24 exceedances), 1990 (2 exceedances), 1991 (27 exceedances), and 1992 (1 exceedance). Although 1,2-dichloroethane has been detected since 1993, none of those concentrations have exceeded the MCL. Other compounds that exceeded MCLs include trichloromethene, benzene, dichloromethane, tetrachloroethane, 1,1-dichloroethene, trichloroethene, tetrachloromethane, and 1,2-dichloropropane.

The co-occurrence and correlation analyses show that VOCs occur together and that their concentrations are positively correlated. The long-term and possible synergistic effects of low concentrations of multiple compounds on human and aquatic health are unknown and an area of active research.

A number of spills, many of which contain petroleum-related products, have released VOCs and other contaminants into the Ohio River and its tributaries. The majority of spills were small and had only local effects. For example, a benzene spill caused by a broken pipe during cold weather in January 1985 at Clairton, $\mathrm{Pa}$., increased benzene concentrations in the Ohio River to $50 \mu \mathrm{g} / \mathrm{L}$, which is 10 times greater than the MCL. Benzene, however, does not persist in water and soil because it biodegrades and volatilizes rapidly to the atmosphere (Environment Canada, 1993). Although spills generally result in short-term exposure, the high concentrations can acutely affect humans and aquatic organisms.

\section{TREND ANALYSIS}

\section{Adjustment for Stream Discharge and Changes in Detection Limits}

In many rivers and streams, some water-quality parameters are a function of stream discharge. For example, point sources may continually discharge VOCs into a river, but an increase in streamflow from storm runoff or snowmelt would dilute the pointsource discharge and decrease concentrations.

Therefore, it may be necessary to adjust concentrations for the variations in stream discharge to distinguish dilution effects from trends in source input (Helsel and Hirsch, 1992).

Because trichloromethane was the most frequently detected VOC in river-water samples from the Ohio River Basin, this compound was evaluated in relation to stream discharge measured at five USGS stream-gaging stations located within $10 \mathrm{mi}$ of an ORSANCO monitoring station (table 12 at end of report, fig. 1). No large tributaries that add substantially to stream discharge enter the Ohio River between these ORSANCO and USGS stations. Discharge measured at nearby USGS stream-gaging stations was considered more reliable than discharge estimated at the ORSANCO monitoring stations from a computer model. Stream discharge and detected trichloromethane concentrations have significant, inverse rank correlations at three of the five ORSANCO stations listed in table 12. These include the ORSANCO stations Neville Island, Pa., Louisville, Ky., and Paducah, Ky. All correlations are very weak ( -0.14 to 0.03 ), suggesting that stream discharge in the Ohio River had little effect on trichloromethane concentrations. Therefore, trend analysis was done without adjusting for stream discharge.

Decreasing the MDL from 0.1 to $0.05 \mu \mathrm{g} / \mathrm{L}$ after 1992 could bias the trends by increasing the percentage 
of detections and decreasing the mean concentrations. Thus, trend analyses were done twice-once using all data that included both MDLs and once using only those detections of $0.1 \mu \mathrm{g} / \mathrm{L}$ and greater throughout the entire 10 -year period.

\section{Time Trend Results}

The monthly mean concentrations and monthly percentage of detections of VOCs were analyzed for time trends using the seasonal Kendall trend test (tables 13 and 14 at end of report). Trend analyses using all data and using detections of $0.1 \mu \mathrm{g} / \mathrm{L}$ and greater produced identical results. The few detected values less than $0.1 \mu \mathrm{g} / \mathrm{L}$ had no measurable effect on trend results and occurred mainly in river-water samples from the Monongahela River at Becks Run, Pa. (station MR4.5), and the Ohio River at Louisville, Ky. (station OR380.4). Assigning zero to nondetections maximizes the slope, but use of a consistent censoring value should not affect the significance of the trend. Although many time trend results were statistically significant, their magnitudes were small because the VOCs were infrequently detected. For example, a trend of less than $0.001 \mu \mathrm{g} / \mathrm{L}$ per year is not considered practically important because the monthly mean concentration would change by less than 10 percent during a 10 -year period. Only significant trends of $0.01 \mu \mathrm{g} / \mathrm{L}$ or 1 percent or more per year were considered practically measurable. Fourteen of the 21 VOCs had statistically and practically significant decreasing trends in monthly mean concentrations in samples from one or more ORSANCO monitoring stations (table 13).

Decreasing trends ranged from -0.01 to $-0.42 \mu \mathrm{g} / \mathrm{L}$ per year with a median of $-0.03 \mu \mathrm{g} / \mathrm{L}$ per year. Examples of typical trends are shown in the time series of trichloromethane concentrations in samples from the Ohio River at Cincinnati, Ohio (station OR518.2), and benzene concentrations in samples from the Kanawha River at St. Albans, W. Va. (station KR38.3) (fig. 26). These results generally show improving water-quality conditions and suggest that efforts to control sources of VOCS are working.

The largest trend of $-0.42 \mu \mathrm{g} / \mathrm{L}$ per year was for 1,2-dichloroethane in samples from the Ohio River at Paducah, Ky. (station OR45.5) (fig. 27). The time series plot shows that concentrations consistently decreased from 1987 through 1993 and that mean concentrations were less than the MDL after 1993. Trichloromethane concentrations in samples from the Ohio River at Huntington, W. Va. (station OR674.1), had a trend of $0.12 \mu \mathrm{g} / \mathrm{L}$ per year and had the only increasing trend in monthly mean concentrations (table 13). Samples from the station just upstream from Huntington, W. Va., on the Ohio River at Parkersburg, W. Va. (station OR790.7), and from the station on the Kanawha River at St. Albans, W. Va. (station KR38.3), had no significant trends for trichloromethane. Therefore, the increase in trichloromethane concentrations in samples from the Ohio River at Huntington, W. Va., is likely from nearby sources.

The time series plot for trichloromethane in samples from the Ohio River at Wheeling, W. Va. (station OR894.2), shows two monotonic trends (fig. 28). A decreasing trend of $-0.07 \mu \mathrm{g} / \mathrm{L}$ per year ( $p$-value less than 0.01) was indicated from 1987 through 1993 and an increasing, but not significant, trend of $0.15 \mu \mathrm{g} / \mathrm{L}$ per year $(\mathrm{p}$-value $=0.11$ ) was indicated from 1994 through 1996. Months with a mean concentration less than the MDL became more common after 1994, which is consistent with the decreasing trend of previous years. The station at Wheeling replaced its gas chromatographs in 1994 and had possible detector problems or in-house sample contamination; therefore, the increase in mean monthly concentrations may be due to those problems (Phillip Kowalski, Wheeling Water Treatment Plant, oral commun., 1999).

Time trend results on the monthly percentage of detections (table 14) were similar to results of the monthly mean concentrations. Many VOCs had statistically significant trends in the monthly percentage of detections, but the magnitude of trend was zero. Among samples from all stations, nine VOCs had statistically and practically significant decreasing trends that ranged from -1.08 to -12.90 percent per year. The station on the Monongahela River at Becks Run, Pa. (station MR4.5), was the only station that showed an increasing trend-an increase in the detection of methylbenzene of 1.61 percent per year. 


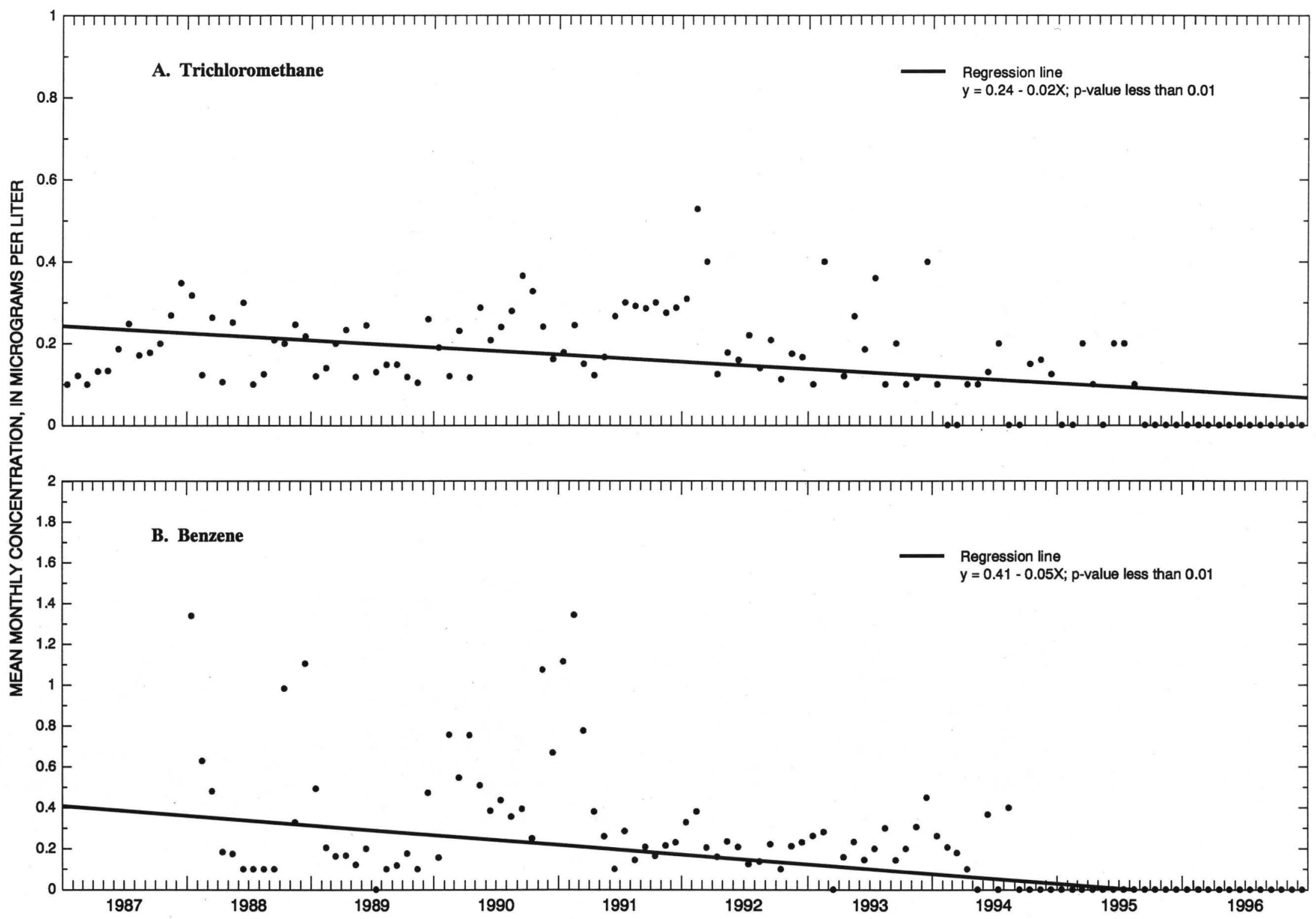

Figure 26. Time series of mean monthly concentrations of (A) trichloromethane in river-water samples from the Ohio River at Cincinnati, Ohio (station OR518.2), and (B) benzene in river-water samples from the Kanawha River at St. Albans, W. Va. (station KR38.3), 1987-96. An outlier trichloromethane concentration of 1.6 micrograms per liter was excluded from the time series for station OR518.2 to more easily see the trend. The independent variable $(X)$ of the regression equation is the number of years from the beginning of the time series, the slope is in micrograms per liter per year, and the intercept is in micrograms per liter. 


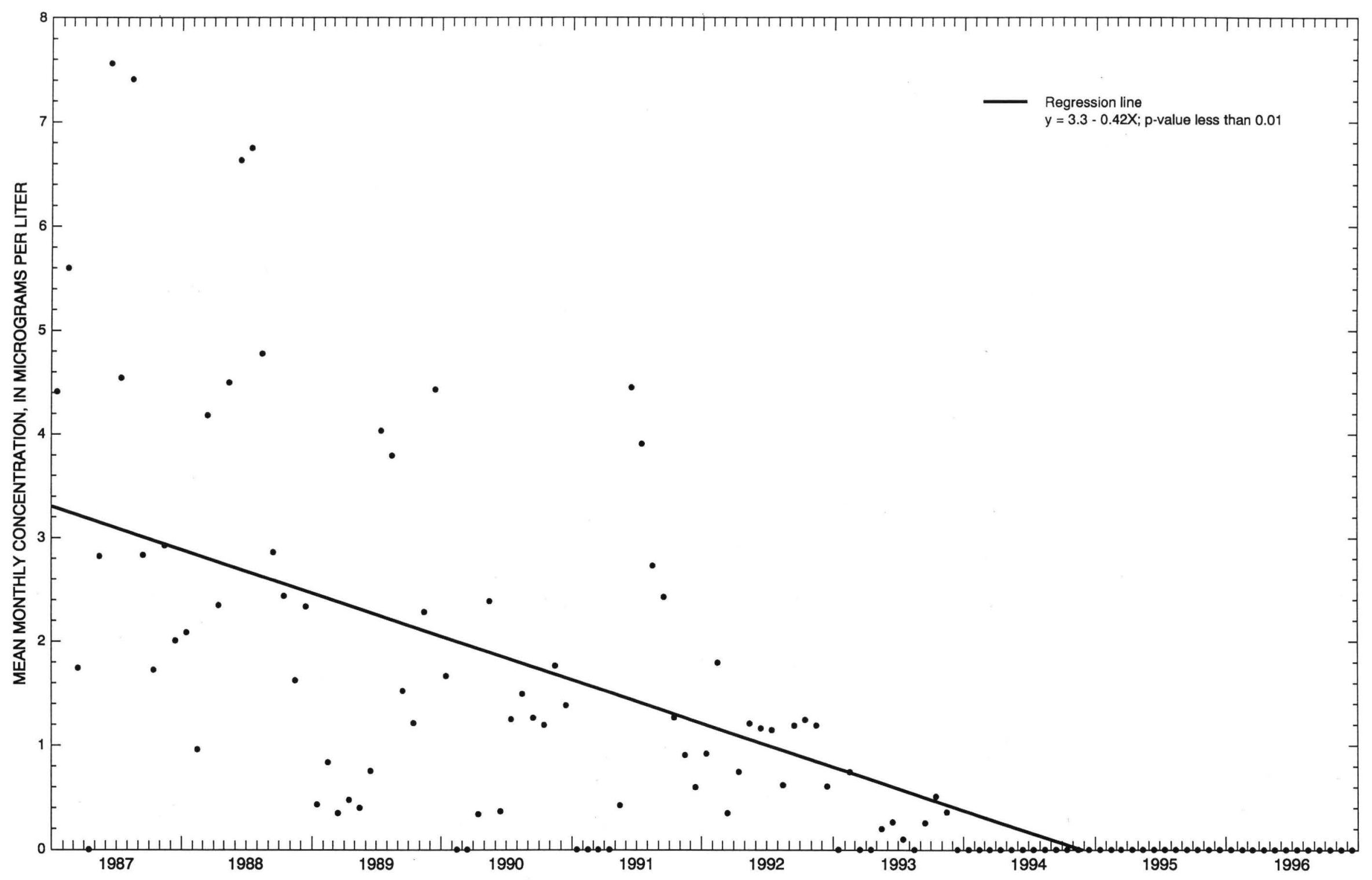

Figure 27. Time series of mean monthly concentrations of 1,2-dichloroethane in river-water samples from the Ohio River at Paducah, Ky. (station OR45.5), 1987-96. The independent variable $(X)$ of the regression equation is the number of years from the beginning of the time series, the slope is in micrograms per liter per year, 


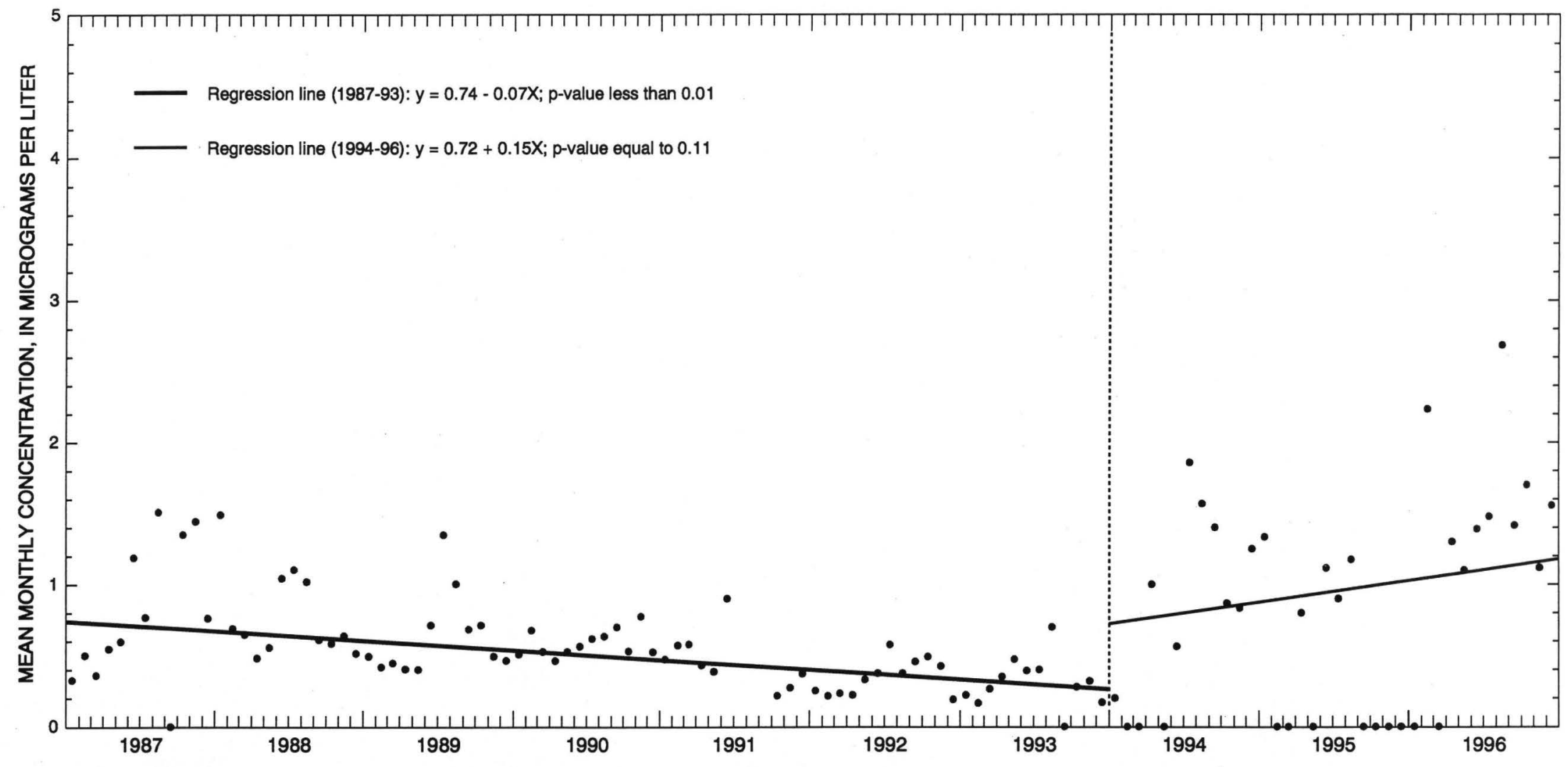

Flgure 28. Time series of mean monthly concentrations of trichloromethane in river-water samples from the Ohio River at Wheeling, W. Va. (station OR894.2), showing two monotonic trends, for $1987-93$ and 1994-96. The independent variable $(X)$ of the regression equation is the number of years from the beginning of the time series, the slope is in micrograms per liter per year, and the intercept is in micrograms per liter. 


\section{SUMMARY}

More than 3 million people depend on the Ohio River as a source of drinking water. Thus, it is important to monitor the water quality of this river to determine if contaminants are present, their concentrations, and if water quality is changing with time. Data on volatile organic compounds (VOCs) in river-water samples from along the Ohio River and its major tributaries were analyzed statistically to determine their occurrence, distribution, and trends from 1987 through 1996. The data were collected by the Ohio River Valley Water Sanitation Commission's Organics Detection System, which monitors daily for VOCs at 15 stations.

The data used for this analysis were from 15 monitoring stations along the Ohio, Allegheny, Monongahela, and Kanawha Rivers. Daily samples of river water were collected from raw-water intake lines prior to any chemical treatment and analyzed for 21 VOCs. The minimum detection level for all VOCs was 0.1 microgram per liter $(\mu \mathrm{g} / \mathrm{L})$ until 1993, when it was decreased to $0.05 \mu \mathrm{g} / \mathrm{L}$. Statistics were done for a basinwide analysis, which uses combined data from all monitoring stations, and for a station-by-station analysis, which uses data from individual monitoring stations.

A total of 44,837 river-water samples were collected at the 15 monitoring stations from 1987 through 1996. Fifty-five percent of the samples had no detection of a VOC, and one or more VOCs were detected in 45 percent of the samples. The maximum number of VOCs detected in a sample was 11 and the median was zero. Trichloromethane, detected in 26 percent of all samples, was the most frequently detected VOC in the Ohio River Basin. Following trichloromethane were benzene (11 percent), methylbenzene ( 6.4 percent), and the other 18 compounds, which were detected in less than 4 percent of samples. Detected concentrations of trichloromethane ranged from 0.05 to $125.3 \mu \mathrm{g} / \mathrm{L}$ with a median of $0.3 \mu \mathrm{g} / \mathrm{L}$. In general, most of the VOCs had median concentrations of 0.1 to $0.4 \mu \mathrm{g} / \mathrm{L}$.

The trihalomethanes (THMs) bromodichloromethane and dibromochloromethane had the highest co-occurrence ( 23 percent) among all VOCs. Isomers of dichlorobenzene also had co-occurrences greater than 20 percent, and the other VOCs had less than 20 percent co-occurrence. Six pairs of VOCs had concentrations that were strongly correlated (Spearman correlation coefficient greater than or equal to 0.7 ). The strong correlation between the THMs bromodichloromethane and dibromochloromethane $(0.80)$ could infer they are from the same source, such as chlorinated water.

The median number of VOCs detected per sample is one in each month, and the percentage of detection of any VOC during the 12 months ranges from 43 to 50 percent compared to the overall detection of 45 percent. The same analysis using detected VOC concentrations had similar results, suggesting temperature has little effect on the occurrence of VOCs in river water of the Ohio River Basin. However, rank-sum tests indicate that benzene, methylbenzene, dichloromethane, and chlorobenzene occurred more frequently during cooler months, and 1,2-dichloroethane, bromodichloromethane, 1,1-dichloroethene, and trichlorofluoromethane occurred more frequently during warmer months. Slower volatilization rates or the increased partitioning from air into water could cause the more frequent detection of benzene and methylbenzene during cooler months. Higher detection frequencies in warmer months compared to cooler months may be attributed to a decrease in stream discharge when inputs of chlorinated water from ground-water sources, wastewater-treatment plants, and other sources comprise a larger fraction of streamflow.

One or more VOCs were detected in 14 to 79 percent of the samples from individual monitoring stations. Six of the 15 stations had VOCs detected in 50 percent or more of the samples. The maximum number of VOCs detected in a sample was 11 from the Kanawha River at St. Albans, W. Va. (station KR38.3). Trichloromethane was the most frequently detected VOC in water from eight stations, benzene was the most frequently detected VOC in water from four stations, and chlorobenzene, 1,3-dichlorobenzene, and 1,2-dichloroethane were the most frequently detected VOCs in water from three stations. Trichloromethane generally was detected most frequently in samples from stations that are near large cities along the Ohio River. Benzene was the most frequently detected VOC in samples from stations in the upstream part of the Ohio River Basin and the Kanawha River. The median detected concentration for most of the VOCs was 
$0.1 \mu \mathrm{g} / \mathrm{L}$ in samples from all stations. In general, samples from stations in the upstream part of the Ohio River Basin and the Kanawha River had the highest sum of VOC concentrations.

Similar to the basinwide analysis, the highest co-occurrences in water from individual monitoring stations were between THMs and isomers of dichlorobenzene. Significant Spearman rank correlations between detected concentrations of THMs and between gasoline-related compounds (benzene, methylbenzene, and ethylbenzene) occurred mostly in samples from stations in the most upstream part of the Ohio River Basin. These correlations could be due to urbanization and associated wastewater discharges. Most of the significant correlations were between solvents, and the greatest number of correlations between solvents was for samples from the Kanawha River and the two stations on the Ohio River that straddle the confluence of the Ohio and Kanawha Rivers. Upstream from the confluence, trichloromethane is correlated mostly with other THMs. On the Kanawha River and downstream from the confluence, trichloromethane is correlated mostly with chlorinated solvents and not with THMs. Benzene is correlated with chlorinated solvents more than gasoline-related compounds throughout the Ohio River Basin. This could suggest that industrial uses of trichloromethane and benzene are the predominant sources of the compounds and not chlorinated water or petroleum products.

The U.S. Environmental Protection Agency has established a Maximum Contaminant Level in drinking water for 18 of the 21 VOCS. More than 99 percent of the raw-water samples contained VOC concentrations within U.S. Environmental Protection Agency drinking-water regulations. The Maximum Contaminant Levels were exceeded in 268 of the 44,837 samples. The compound 1,2-dichloroethane in samples from the Ohio River at Paducah, Ky. (station OR45.5), accounted for 188 of the exceedances. This VOC has been detected infrequently in samples from this monitoring station since 1992. Other exceedances generally occurred in the upstream part of the basin and the Kanawha River.

Trend analyses were done using all detections at the two different minimum detection levels and only using detections of $0.1 \mu \mathrm{g} / \mathrm{L}$ and greater for the 10 -year period from 1987 through 1996. Results using the two data sets were identical, indicating trends were not an artifact of decreasing the minimum detection level. Trend analysis for the monthly mean concentrations showed that among the samples from the 15 monitoring stations, 14 of the 21 VOCs detected had statistically and practically significant decreasing trends ranging from -0.01 to $-0.42 \mu \mathrm{g} / \mathrm{L}$ per year. Trichloromethane concentrations in samples from the Ohio River at Huntington, W. Va. (station OR674.1), had a trend of $0.12 \mu \mathrm{g} / \mathrm{L}$ per year and had the only increasing trend in monthly mean concentrations. Trend analysis on the monthly percentage detections produced similar results. Among river-water samples from all stations, nine VOCs had statistically and practically significant decreasing trends that ranged from -1.08 to -12.90 percent per year. The station on the Monongahela River at Becks Run, Pa. (station MR4.5), was the only station that showed an increasing trend-an increase in the detection of methylbenzene of 1.61 percent per year. The monthly decreasing trends indicate improving water quality and suggest that source-control efforts are working.

Most VOC detections in the Ohio River Basin are at low concentrations. Potential sources of VOCs include point sources, such as industrial and municipal discharges, ground-water contamination sites, and commercial navigation, and nonpoint-source pollution.

\section{REFERENCES CITED}

Ammore, J.E., and Hautala, Earl, 1983, Odor as an aid to chemical safety - Odor thresholds compared with threshold limit values and volatiles for 214 industrial chemicals in air and water dilution: Journal of Applied Toxicology, v. 3, no. 6, p. 272-290.

Barber, L.B., II, Leenheer, J.A., Tabor, C.F., Brown, G.K., Noyes, T.I., and Noriega, M.C., 1995, Organic compounds and sewage-derived contaminants, in Moody, J.A., ed., Chemical data for water supplies collected during four upriver cruises on the Mississippi River between New Orleans, Louisiana, and Minneapolis, Minnesota, May 1990-April 1992: U.S. Geological Survey Open-File Report 94-523, p. 211-297.

Bellar, T.A., Lichtenberg, J.J., and Kroner, R.C., 1974, The occurrence of organohalides in chlorinated drinking waters: Journal of the American Water Works Association, v. 66, no. 12, p. 703-706. 
Bender, D.A., Zogorski, J.S., Halde, M.J., and Rowe, B.L., 1999, Selection procedure and salient information for volatile organic compounds emphasized in the National Water-Quality Assessment Program: U.S. Geological Survey Open-File Report 99-182, 32 p.

Bloemen, H.J. Th., and Burn, J., eds., 1993, Chemistry and analysis of volatile organic compounds in the environment: Glasgow, Scotland, Blackie Academic and Professional, 290 p.

Environment Canada, 1993, Priority substances list assessment report on benzene, in Irwin, R.J., ed., Environmental contaminants encyclopedia: Fort Collins, Colo., National Park Service Water Resources Division, 1998, accessed May 28, 1999, at URL http://www.aqd.nps.gov/toxic/index.html.

Gilliom, R.J., Alley, W.M., and Gurtz, M.E., 1995, Design of the National Water-Quality Assessment Program-Occurrence and distribution of water-quality conditions: U.S. Geological Survey Circular 1112, 33 p.

Hadley, E.H., 1988a, Benzene, in Irwin, R.J., ed., Environmental Contaminants Encyclopedia: Fort Collins, Colo., National Park Service Water Resources Division, 1998, accessed May 28, 1999, at URL http://www.aqd.nps.gov/toxic/index.html.

1988b, Toluene, in Irwin, R.J., ed., Environmental Contaminants Encyclopedia: Fort Collins, Colo., National Park Service Water Resources Division, 1998, accessed May 28, 1999, at URL

http://www.aqd.nps.gov/toxic/index.html.

Helmig, Detlev, Klinger, L.F., Guenther, Alex, Vierling, Lee, Geron, Chris, and Zimmerman, Patrick, 1999, Biogenic volatile organic compound emissions (BVOCs) - I. Identification from three continental sites in the U.S.: Chemosphere, v. 38, no. 9, p. 2163-2187.

Helsel, D.R., and Hirsch, R.M., 1992, Statistical methods in water resources: New York, Elsevier Science, 522 p.

Hirsch, R.M., and Slack, J.R., 1984, A nonparametric trend test for seasonal data with serial dependence: Water Resources Research, v. 20, no. 6, p. 727-732.

Hirsch, R.M., Slack, J.R., and Smith, R.A., 1982, Techniques of trend analysis for monthly water-quality data: Water Resources Research, v. 18, no. 6, p. $107-121$.
Hoekman, S.K., 1992, Speciated measurements and calculated reactivities of vehicle exhaust emissions from conventional and reformulated gasoline: Environmental Science and Technology, v. 26, no. 6, p. 1206-1216.

International Agency for Research on Cancer (IARC) Working Group on the Evaluation of Carcinogenic Risks to Humans, 1991, Chlorinated drinking-water, chlorination by-products - Some other halogenated compounds, cobalt and cobalt compounds: Lyon, France, World Health Organization, International Agency for Research on Cancer, IARC, 544 p.

Kotzias, D., and Sparta, C., 1993, VOCs and water pollution, in Bloemen, H.J. Th., and Burn, J., eds., Chemistry and analysis of volatile organic compounds in the environment: Glasgow, Scotland, Blackie Academic and Professional, p. 175-201.

Lopes, T.J., and Bender, D.A., 1998, Nonpoint sources of volatile organic compounds in urban areas-Relative importance of land surfaces and air: Environmental Pollution, v. 101, p. 221-230.

Lopes, T.J., and Price, C.V., 1997, Study plan for urban stream indicator sites of the National Water-Quality Assessment Program: U.S. Geological Survey Open-File Report 97-25, 15 p.

Lucius, J.E., Olhoeft, G.R., Hill, P.L., and Duke, S.K., 1989 , Properties and hazards of 108 selected substances: U.S. Geological Survey Open-File Report 89-491, 538 p.

Minear, R.A., and Amy, G.L., eds., 1995, Disinfection by-products in water treatment: The chemistry of their formation and control: New York, Lewis Publ., 502 p.

Ohio River Valley Water Sanitation Commission, 1981, Early warning-Organics detection system: Cincinnati, Ohio, Ohio River Valley Water Sanitation Commission, final report of two years operation under USEPA grant, September 1981, 103 p.

1992, Water quality trends, Ohio River and its tributaries-Organic compounds: Cincinnati, Ohio, Ohio River Valley Water Sanitation Commission, June 1992, 27 p.

1994, Assessment of water quality conditions - Ohio River main stem, Water years 1992-1993: Cincinnati, Ohio, Ohio River Valley Water Sanitation Commission, December 1994, 51 p. 
Pankow, J.F., and Cherry, J.A., 1996, Dense chlorinated solvents and other DNAPLs in groundwater: Portland, Oregon, Waterloo Press, 522 p.

Rathbun, R.E., 1998, Transport, behavior, and fate of volatile organic compounds in streams: U.S. Geological Survey Professional Paper 1589, 151 p.

Rook, J.J., 1974, Formation of haloforms during chlorination of natural waters: Water Treatment and Examination, v. 23, no. 2, p. 234-243.

SAS Institute, Inc., 1990, SAS procedures guide, version 6 (3d ed.): Cary, North Carolina, 705 p.

Schertz, T.L., Alexander, R.B., and Ohe, D.L., 1991, The computer program EStimate TREND (ESTREND), a system for the detection of trends in water-quality data: U.S. Geological Survey Water-Resources Investigations Report 91-4040, 63 p.

Sheskin, D.J., 1997, Handbook of parametric and nonparametric statistical procedures: Boca Raton, Fla., CRC Press, Inc., 719 p.

Smith, R.S., Hirsch, R.M., and Slack, J.R., 1982, A study of trends in total phosphorus at NASQAN stations: U.S. Geological Survey Water-Supply Paper 2190, 31 p.

Squillace, P.J., and Price, C.V., 1996, Urban land-use study plan for the National Water-Quality Assessment Program: U.S. Geological Survey Open-File Report 96-217, $19 \mathrm{p}$.

Swan, S.H., Waller, K., Hopkins, B., Windham, G., Fenster, L., Schaefer, C., and Neutra, R.R., 1998, A prospective study of spontaneous abortion-Relation to amount and source of drinking water consumed in early pregnancy: Epidemiology, v. 9, no. 2, p. 126-133.

Tennant, P.A., Norman, C.G., and Vicory, A.H., Jr., 1992, The Ohio River Valley Water Sanitation Commission's Toxic Substances Control Program for the Ohio River: Water Science and Technology, v. 26, no. 7-8, p. $1779-1788$.

U.S. Environmental Protection Agency, 1985, Oil and Hazardous Materials/Technical Assistance Data System (OHM/TADS), in Irwin, R.J., ed., Environmental contaminants encyclopedia: Fort Collins, Colo., National Park Service Water Resources Division, 1998, accessed May 28, 1999, at URL http://www.aqd.nps.gov/toxic/index.html.
1994, Is your drinking water safe?: Washington, D.C., EPA 810-F-94-002, May 1994, 19 p.

-1996, Drinking water regulations and health advisories: Washington, D.C., EPA 822-B-96-002, October 1996, 13 p.

1998, 1996 Toxic release inventory-Public data release-Ten years of right-to-know: Office of Pollution Prevention and Toxics, Washington, D.C., EPA 745-R-98-005, 408 p. with appendices.

Verschueren, Karel, 1983, Handbook of environmental data on organic chemicals ( $2 \mathrm{~d}$ ed.): New York, Van Nostrand Reinhold, $1310 \mathrm{p}$.

Wallace, L.A., 1993, VOCs and the environment and public health-exposure, in Bloemen, H.J. Th., and Burn, J., eds., Chemistry and analysis of volatile organic compounds in the environment: Glasgow, Scotland, Blackie Academic and Professional, p. 1-24.

Westrick, J.J., Mello, J.W., and Thomas, R.F., 1984, The groundwater supply survey: Journal of the American Water Works Association, v. 76, no. 5, p. 52-59. 
Table 1. Volatile organic compounds (VOCs) analyzed by the Ohio River Valley Water Sanitation Commission (ORSANCO)

[STORET, U.S. Environmental Protection Agency Storage and Retrieval System; IUPAC, International Union of Pure and Applied Chemistry;

CAS number, Chemical Abstract Services number; --, not applicable]

\begin{tabular}{|c|c|c|c|}
\hline $\begin{array}{l}\text { STORET } \\
\text { parameter } \\
\text { code }\end{array}$ & IUPAC compound name & $\begin{array}{c}\text { CAS } \\
\text { number }\end{array}$ & Common name(s) \\
\hline 34030 & Benzene & $71-43-2$ & -- \\
\hline 32101 & Bromodichloromethane & $75-27-4$ & dichlorobromomethane \\
\hline 34301 & Chlorobenzene & $108-90-7$ & monochlorobenzene \\
\hline 32105 & Dibromochloromethane & $124-48-1$ & chlorodibromoethane \\
\hline 34536 & 1,2-Dichlorobenzene & $95-50-1$ & o-Dichlorobenzene; 1,2-DCB \\
\hline 34566 & 1,3-Dichlorobenzene & $541-73-1$ & $m$-dichlorobenzene; 1,3 -DCB \\
\hline 34571 & 1,4-Dichlorobenzene & $106-46-7$ & p-dichlorobenzene; 1,4-DCB \\
\hline 34496 & 1,1-Dichloroethane & $75-34-3$ & ethylidene chloride \\
\hline 34531 & 1,2-Dichloroethane & $107-06-2$ & ethylene dichloride \\
\hline 34501 & 1,1-Dichloroethene & $75-35-4$ & vinylidene chloride \\
\hline 34423 & Dichloromethane & $75-09-2$ & methylene chloride \\
\hline 34541 & 1,2-Dichloropropane & $78-87-5$ & propylene dichloride \\
\hline 78113 & Ethylbenzene & $100-41-4$ & phenylethane \\
\hline 78131 & Methylbenzene & $108-88-3$ & toluene \\
\hline 34475 & Tetrachloroethene & $127-18-4$ & perchloroethene; PCE \\
\hline 32102 & Tetrachloromethane & $56-23-5$ & carbon tetrachloride \\
\hline 32104 & Tribromomethane & $75-25-2$ & bromoform \\
\hline 34506 & 1,1,1-Trichloroethane & $71-55-6$ & methylchloroform \\
\hline 39180 & Trichloroethene & $79-01-6$ & trichloroethylene; TCE \\
\hline 34488 & Trichlorofluoromethane & $75-69-4$ & CFC 11 \\
\hline 32106 & Trichloromethane & $67-66-3$ & chloroform \\
\hline
\end{tabular}


Table 2. Ohio River Valley Water Sanitation Commission (ORSANCO) Organic Detection System (ODS) monitoring stations used for this study

[STORET, U.S. Environmental Protection Agency Storage and Retrieval System; River miles are from the confluence of the Allegheny and Monongahela Rivers except as indicated; --, not applicable]

\begin{tabular}{|c|c|c|c|c|c|c|c|}
\hline \multirow{2}{*}{$\begin{array}{c}\text { Monitoring } \\
\text { station } \\
\text { identifier } \\
\text { (STORET } \\
\text { primary } \\
\text { number) } \\
\text { (fig. 1) }\end{array}$} & \multirow[b]{2}{*}{ Station name } & \multicolumn{2}{|c|}{ River miles } & \multirow[b]{2}{*}{ Station description } & \multirow{2}{*}{$\begin{array}{l}\text { Latitude } \\
\text { (degrees, } \\
\text { minutes, } \\
\text { seconds) }\end{array}$} & \multirow{2}{*}{$\begin{array}{l}\text { Longitude } \\
\text { (degrees, } \\
\text { minutes, } \\
\text { seconds) }\end{array}$} & \multirow{2}{*}{$\begin{array}{c}\text { Period of record used for } \\
\text { analysis } \\
\text { (month/day/year) }\end{array}$} \\
\hline & & Ohio River & Tributary & & & & \\
\hline${ }^{1} \mathrm{AR} 7.40$ & City of Pittsburgh Water Treatment Plant & -- & 7.4 & Allegheny River at Pittsburgh, $\mathrm{Pa}$. & $40^{\circ} 29^{\prime} 40^{\prime \prime}$ & $79^{\circ} 49^{\prime} 30^{\prime \prime}$ & $1 / 01 / 1987-12 / 31 / 1996$ \\
\hline${ }^{1} \mathrm{MR} 4.5$ & $\begin{array}{l}\text { Pa.-American Water Company Hays } \\
\text { Mine Lab }\end{array}$ & -- & 4.5 & $\begin{array}{l}\text { Monongahela River at Becks Run, } \\
\text { Pa. }\end{array}$ & $40^{\circ} 24^{\prime} 36^{\prime \prime}$ & $79^{\circ} 57^{\prime} 15^{\prime \prime}$ & $1 / 01 / 1987-12 / 31 / 1996$ \\
\hline OR976.50 & West View Water Authority, Pa. & 4.5 & -- & Ohio River at Neville Island, Pa. & $40^{\circ} 29^{\prime} 34^{\prime \prime}$ & $80^{\circ} 04^{\prime} 18^{\prime \prime}$ & $1 / 01 / 1987-12 / 31 / 1996$ \\
\hline OR946.1 & Shippingport, Pa. (Beaver Valley) & 34.9 & -- & Ohio River at Shippingport, $\mathrm{Pa}$. & $40^{\circ} 37^{\prime} 30^{\prime \prime}$ & $80^{\circ} 26^{\prime} 00^{\prime \prime}$ & $2,33 / 01 / 1990-12 / 31 / 1996$ \\
\hline OR9408 & $\begin{array}{l}\text { City of East Liverpool Water Works, } \\
\text { Ohio }\end{array}$ & 40.2 & -- & Ohio River at East Liverpool, Ohio & $40^{\circ} 38^{\prime} 20^{\prime \prime}$ & $80^{\circ} 31^{\prime} 15^{\prime \prime}$ & ${ }^{2} 1 / 02 / 1987-12 / 31 / 1996$ \\
\hline OR9159 & Weirton, W. Va. & 62.5 & -- & Ohio River at Weirton, W. Va. & $40^{\circ} 23^{\prime} 20^{\prime \prime}$ & $80^{\circ} 37^{\prime} 49^{\prime \prime}$ & $2,{ }^{3} 10 / 01 / 1990-12 / 31 / 1996$ \\
\hline OR894.2 & Wheeling Water Treatment Plant, W. Va. & 86.8 & -- & Ohio River at Wheeling, W. Va. & $40^{\circ} 04^{\prime} 18^{\prime \prime}$ & $80^{\circ} 43^{\prime} 34.5^{\prime \prime}$ & ${ }^{2} 1 / 02 / 1987-12 / 31 / 1996$ \\
\hline OR790.7 & $\begin{array}{l}\text { E.I. duPont deNemours \& Co. } \\
\text { Parkersburg, W. Va. }\end{array}$ & 190.3 & -- & Ohio River at Parkersburg, W. Va. & $39^{\circ} 15^{\prime} 46^{\prime \prime}$ & $81^{\circ} 40^{\prime} 04^{\prime \prime}$ & ${ }^{2} 7 / 01 / 1987-12 / 04 / 1996$ \\
\hline${ }^{1} \mathrm{KR} 38.3$ & $\begin{array}{l}\text { Appalachian Power Company St. Albans, } \\
\text { W. Va. }\end{array}$ & -- & ${ }^{4} 38.3$ & Kanawha River at St. Albans, W. Va. & $38^{\circ} 23^{\prime} 30^{\prime \prime}$ & $81^{\circ} 49^{\prime} 56^{\prime \prime}$ & ${ }^{2} 7 / 07 / 1987-12 / 31 / 1996$ \\
\hline OR674.1 & Huntington, W. Va.-American Water Co. & 306.9 & -- & Ohio River at Huntington, W. Va. & $38^{\circ} 25^{\prime} 57^{\prime \prime}$ & $82^{\circ} 25^{\prime} 27^{\prime \prime}$ & 1/01/1987-12/31/1996 \\
\hline OR630.9 & $\begin{array}{l}\text { City of Portsmouth Water Treatment } \\
\text { Plant, Ohio }\end{array}$ & 350.7 & -- & Ohio River at Portsmouth, Ohio & $38^{\circ} 43^{\prime} 45^{\prime \prime}$ & $82^{\circ} 59^{\prime} 49.5^{\prime \prime}$ & 1/01/1987-12/31/1996 \\
\hline OR518.2 & City of Cincinnati Water Works, Ohio & 462.8 & -- & Ohio River at Cincinnati, Ohio & $39^{\circ} 04^{\prime} 11^{\prime \prime}$ & $84^{\circ} 25^{\prime} 57^{\prime \prime}$ & $1 / 01 / 1987-12 / 31 / 1996$ \\
\hline OR380.4 & Louisville Water Company, Ky. & 600.6 & -- & Ohio River at Louisville, Ky. & $38^{\circ} 16^{\prime} 52^{\prime \prime}$ & $85^{\circ} 42^{\prime} 08^{\prime \prime}$ & $1 / 01 / 1987-12 / 31 / 1996$ \\
\hline OR189.5 & Evansville Water Works, Ind. & 791.5 & -- & Ohio River at Evansville, Ind. & $37^{\circ} 58^{\prime} 20^{\prime \prime}$ & $87^{\circ} 34^{\prime} 35^{\prime \prime}$ & $1 / 01 / 1987-12 / 31 / 1996$ \\
\hline OR45.5 & Paducah Water Works, Ky. & 935.5 & -- & Ohio River at Paducah, Ky. & $37^{\circ} 06^{\prime} 00^{\prime \prime}$ & $88^{\circ} 36^{\prime} 30^{\prime \prime}$ & ${ }^{2} 1 / 05 / 1987-12 / 09 / 1996$ \\
\hline
\end{tabular}

${ }^{1}$ Indicates ORSANCO stations not along the Ohio River main stem.

${ }^{2}$ Indicates ORSANCO stations not having a complete 10 years of record.

${ }^{3}$ Added in March 1990 (OR946.1) and September 1990 (OR9159).

${ }^{4}$ River miles are from the confluence of the Kanawha and Ohio Rivers. 
Table 3. Statistical summary of volatile organic compounds (VOCs) detected in all river-water samples from the Ohio River Basin, 1987-96

[Data from U.S. Environmental Protection Agency Storage and Retrieval (STORET) System; IUPAC, International Union of Pure and Applied Chemistry; Compounds are listed in order of frequency of detection; Minimum detection limit 0.05 microgram per liter]

\begin{tabular}{|c|c|c|c|c|c|c|c|c|}
\hline \multirow{2}{*}{$\begin{array}{l}\text { IUPAC compound } \\
\text { name }\end{array}$} & \multirow{2}{*}{$\begin{array}{l}\text { Number of } \\
\text { detections }\end{array}$} & \multirow{2}{*}{$\begin{array}{c}\text { Total } \\
\text { number of } \\
\text { samples }\end{array}$} & \multirow{2}{*}{$\begin{array}{c}\text { Frequency } \\
\text { of } \\
\text { detection } \\
\text { (percent) }\end{array}$} & \multicolumn{5}{|c|}{ Detected concentrations, in micrograms per liter } \\
\hline & & & & Mean & $\begin{array}{l}\text { Standard } \\
\text { deviation }\end{array}$ & Median & Minimum & Maximum \\
\hline Trichloromethane & 11,700 & 44,836 & 26.1 & 0.7 & 1.9 & 0.3 & 0.05 & 125.3 \\
\hline Benzene & 4,505 & 41,040 & 11.0 & .3 & 1.5 & .1 & .05 & 89.0 \\
\hline Methylbenzene & 1,514 & 23,743 & 6.4 & .2 & .4 & .1 & .05 & 11.7 \\
\hline Dichloromethane & 1,741 & 44,837 & 3.9 & .5 & 1.0 & .2 & .06 & 13.4 \\
\hline 1,3-Dichlorobenzene & 1,406 & 41,040 & 3.4 & .3 & 1.1 & .1 & .1 & 23.2 \\
\hline 1,2-Dichloroethane & 1,421 & 44,837 & 3.2 & 2.4 & 2.8 & 1.3 & .1 & 22.1 \\
\hline Tetrachloroethene & 1,387 & 44,835 & 3.1 & .4 & .8 & .1 & .07 & 12.2 \\
\hline Bromodichloromethane & 1,338 & 44,836 & 3.0 & .7 & 1.5 & .3 & .1 & 22.1 \\
\hline 1,4-Dichlorobenzene & 1,197 & 41,040 & 2.9 & .3 & 1.4 & .1 & .1 & 42.4 \\
\hline 1,2-Dichlorobenzene & 1,111 & 41,040 & 2.7 & .2 & .6 & .1 & .1 & 17.0 \\
\hline Chlorobenzene & 1,203 & 44,835 & 2.7 & .3 & .8 & .2 & .1 & 22.0 \\
\hline 1,1-Dichloroethene & 1,013 & 44,837 & 2.3 & 1.0 & 5.0 & .4 & .06 & 145.4 \\
\hline 1,1,1-Trichloroethane & 867 & 44,837 & 1.9 & .6 & 3.2 & .2 & .06 & 84.2 \\
\hline Ethylbenzene & 314 & 23,743 & 1.3 & .4 & 2.9 & .1 & .07 & 47.8 \\
\hline Dibromochloromethane & 496 & 44,835 & 1.1 & .8 & 1.9 & .3 & .1 & 20.7 \\
\hline Trichloroethene & 496 & 44,835 & 1.1 & .3 & .5 & .1 & .1 & 5.5 \\
\hline Tetrachloromethane & 303 & 44,836 & .7 & .9 & 2.0 & .2 & .1 & 19.6 \\
\hline 1,1-Dichloroethane & 298 & 44,837 & .7 & 1.4 & 6.4 & .3 & .1 & 99.7 \\
\hline Trichlorofluoromethane & 228 & 44,837 & .5 & 3.3 & 3.6 & 2.3 & .1 & 20.4 \\
\hline 1,2-Dichloropropane & 174 & 44,836 & .4 & .9 & 2.1 & .2 & .1 & 11.0 \\
\hline Tribromomethane & 158 & 44,835 & .4 & .3 & .2 & .2 & .1 & .9 \\
\hline
\end{tabular}


Table 4. Number of samples with volatile organic compound (VOC) pairs detected in river-water samples from the Ohio River Basin, 1987-96

[PCODE, U.S. Environmental Protection Agency Storage and Retrieval (STORET) System parameter code; P32106, trichloromethane; P34030, benzene; P78131, methylbenzene; P34423,

dichloromethane; P34566, 1,3-dichlorobenzene; P34531, 1,2-dichloroethane; P34475, tetrachloroethene; P32101, bromodichloromethane; P34571, 1,4-dichlorobenzene; P34536, 1,2-dichlorobenzene;

P34301, chlorobenzene; P34501, 1,1-dichloroethene; P34506, 1,1,1-trichloroethane; P78113, ethylbenzene; P32105, dibromochloromethane; P39180, trichloroethene; P32102, tetrachloromethane;

P34496, 1,1-dichloroethane; P34488, trichlorofluoromethane; P34541, 1,2-dichloropropane; P32104, tribromomethane; bold numbers indicate percentage of co-occurrences greater than 20 percent; --,

redundant pair]

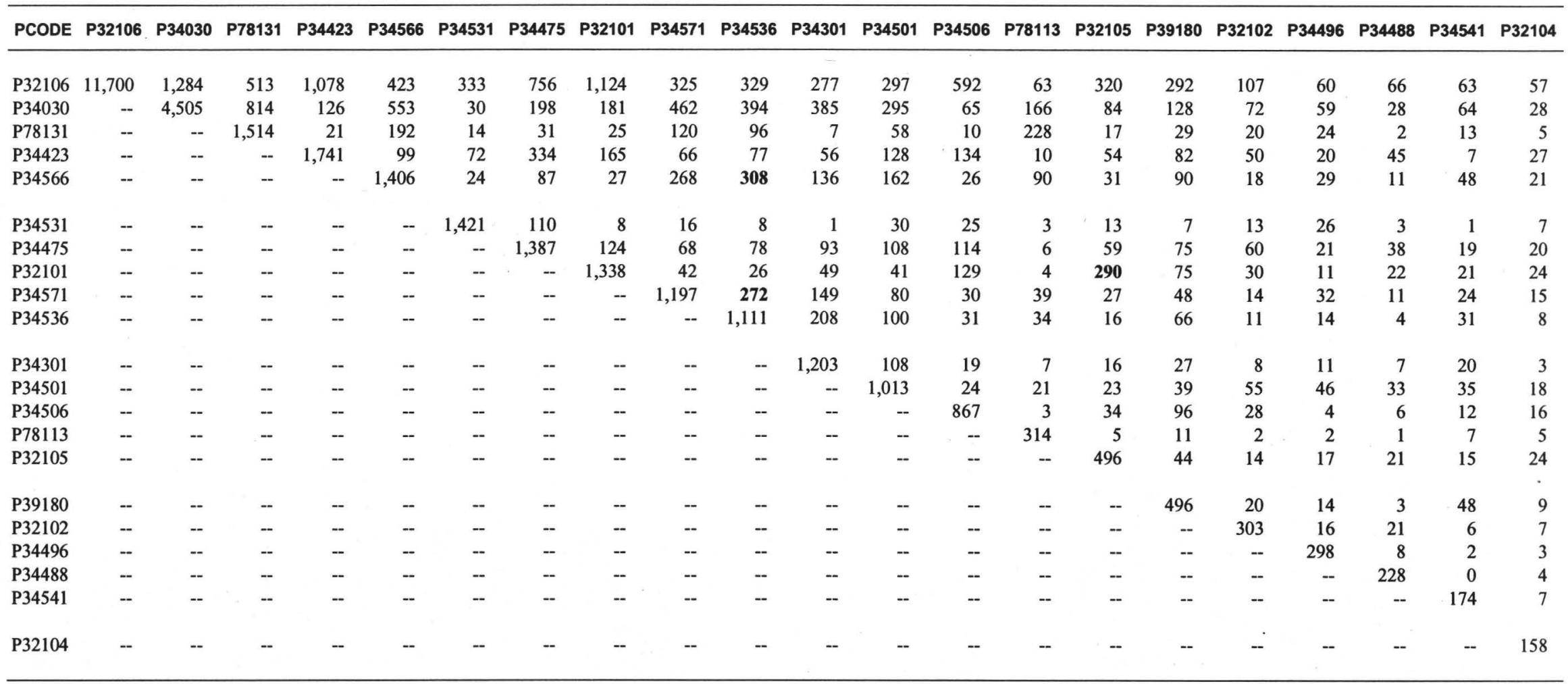


Table 5. Statistically significant correlations between concentrations of volatile organic compounds (VOCs) detected in river-water samples from the Ohio River Basin, 1987-96

[Note: Correlations computed only for number of observations greater than or equal to $5 ;<$, less than; bold numbers indicate strong correlations greater than 0.7 ]

\begin{tabular}{|c|c|c|c|c|}
\hline \multicolumn{2}{|c|}{ Correlated VOCs } & \multirow{2}{*}{$\begin{array}{c}\begin{array}{c}\text { Spearman correlation } \\
\text { coefficient }\end{array} \\
0.27\end{array}$} & \multirow{2}{*}{$\begin{array}{l}\text { p-value } \\
<0.01\end{array}$} & \multirow{2}{*}{$\begin{array}{c}\begin{array}{c}\text { Number of } \\
\text { observations }\end{array} \\
1,284\end{array}$} \\
\hline Trichloromethane & Benzene & & & \\
\hline Trichloromethane & Methylbenzene & -.11 & .02 & 513 \\
\hline Trichloromethane & Dichloromethane & .12 & $<.01$ & 1,078 \\
\hline Trichloromethane & 1,3-Dichlorobenzene & .23 & $<.01$ & 423 \\
\hline Trichloromethane & Tetrachloroethene & .14 & $<.01$ & 756 \\
\hline Trichloromethane & Bromodichloromethane & .62 & $<.01$ & 1,124 \\
\hline Trichloromethane & 1,4-Dichlorobenzene & .15 & $<.01$ & 325 \\
\hline Trichloromethane & 1,1,1-Trichloroethane & .23 & $<.01$ & 592 \\
\hline Trichloromethane & Dibromochloromethane & .44 & $<.01$ & 320 \\
\hline Trichloromethane & Trichloroethene & .14 & .01 & 292 \\
\hline Trichloromethane & 1,1-Dichloroethane & .41 & $<.01$ & 60 \\
\hline Trichloromethane & Trichlorofluoromethane & -.30 & .01 & 66 \\
\hline Trichloromethane & 1,2-Dichloropropane & .75 & $<.01$ & 63 \\
\hline Trichloromethane & Tribromomethane & .40 & $<.01$ & 57 \\
\hline Benzene & Methylbenzene & .40 & $<.01$ & 814 \\
\hline Benzene & 1,3-Dichlorobenzene & .34 & $<.01$ & 553 \\
\hline Benzene & Tetrachloroethene & .23 & $<.01$ & 198 \\
\hline Benzene & 1,4-Dichlorobenzene & .33 & $<.01$ & 462 \\
\hline Benzene & 1,2-Dichlorobenzene & .26 & $<.01$ & 394 \\
\hline Benzene & Ethylbenzene & .24 & $<.01$ & 166 \\
\hline Benzene & Trichloroethene & .23 & $<.01$ & 128 \\
\hline Benzene & Tetrachloromethane & .58 & $<.01$ & 72 \\
\hline Benzene & 1,1-Dichloroethane & .44 & $<.01$ & 59 \\
\hline Benzene & 1,2-Dichloropropane & .36 & $<.01$ & 64 \\
\hline Methylbenzene & 1,3-Dichlorobenzene & .26 & $<.01$ & 192 \\
\hline Methylbenzene & 1,2-Dichlorobenzene & .35 & $<.01$ & 96 \\
\hline Methylbenzene & Ethylbenzene & .14 & .03 & 228 \\
\hline Methylbenzene & 1,2-Dichloropropane & .60 & .03 & 13 \\
\hline Dichloromethane & 1,3-Dichlorobenzene & .29 & $<.01$ & 99 \\
\hline Dichloromethane & Tetrachloroethene & .50 & $<.01$ & 334 \\
\hline Dichloromethane & Bromodichloromethane & .27 & $<.01$ & 165 \\
\hline Dichloromethane & 1,1-Dichloroethene & .38 & $<.01$ & 128 \\
\hline Dichloromethane & Dibromochloromethane & .44 & $<.01$ & 54 \\
\hline Dichloromethane & Trichloroethene & .38 & $<.01$ & 82 \\
\hline Dichloromethane & 1,1-Dichloroethane & .73 & $<.01$ & 20 \\
\hline 1,3-Dichlorobenzene & Tetrachloroethene & .22 & .04 & 87 \\
\hline 1,3-Dichlorobenzene & Bromodichloromethane & .53 & $<.01$ & 27 \\
\hline 1,3-Dichlorobenzene & 1,4-Dichlorobenzene & .56 & $<.01$ & 268 \\
\hline 1,3-Dichlorobenzene & 1,2-Dichlorobenzene & .42 & $<.01$ & 308 \\
\hline 1,3-Dichlorobenzene & Ethylbenzene & .50 & $<.01$ & 90 \\
\hline
\end{tabular}


Table 5. Statistically significant correlations between concentrations of volatile organic compounds (VOCs) detected in river-water samples from the Ohio River Basin, 1987-96-Continued

[Note: Correlations computed only for number of observations greater than or equal to 5 ; <, less than; bold numbers indicate strong correlations greater than 0.7$]$

\begin{tabular}{|c|c|c|c|c|}
\hline \multicolumn{2}{|c|}{ Correlated VOCs } & \multirow{2}{*}{$\begin{array}{c}\begin{array}{c}\text { Spearman correlation } \\
\text { coefficient }\end{array} \\
0.49\end{array}$} & \multirow{2}{*}{$\begin{array}{c}\text { p-value } \\
<0.01\end{array}$} & \multirow{2}{*}{$\begin{array}{c}\begin{array}{c}\text { Number of } \\
\text { observations }\end{array} \\
31\end{array}$} \\
\hline 1,3-Dichlorobenzene & Dibromochloromethane & & & \\
\hline 1,3-Dichlorobenzene & 1,2-Dichloropropane & .50 & $<.01$ & 48 \\
\hline 1,2-Dichloroethane & 1,4-Dichlorobenzene & .59 & .02 & 16 \\
\hline 1,2-Dichloroethane & 1,1,1-Trichloroethane & .57 & $<.01$ & 25 \\
\hline 1,2-Dichloroethane & Tetrachloromethane & .58 & .04 & 13 \\
\hline Tetrachloroethene & Bromodichloromethane & .44 & $<.01$ & 124 \\
\hline Tetrachloroethene & 1,4-Dichlorobenzene & .25 & .04 & 68 \\
\hline Tetrachloroethene & 1,2-Dichlorobenzene & .25 & .03 & 78 \\
\hline Tetrachloroethene & Trichloroethene & .32 & $<.01$ & 75 \\
\hline Tetrachloroethene & 1,1-Dichloroethene & .44 & $<.01$ & 108 \\
\hline Tetrachloroethene & 1,1,1-Trichloroethane & .20 & .03 & 114 \\
\hline Tetrachloroethene & 1,1-Dichloroethane & .46 & .04 & 21 \\
\hline Tetrachloroethene & Trichlorofluoromethane & .33 & .04 & 38 \\
\hline Bromodichloromethane & 1,1,1-Trichloroethane & .49 & $<.01$ & 129 \\
\hline Bromodichloromethane & Dibromochloromethane & .80 & $<.01$ & 290 \\
\hline Bromodichloromethane & Trichloroethene & .46 & $<.01$ & 75 \\
\hline Bromodichloromethane & Tetrachloromethane & .61 & $<.01$ & 30 \\
\hline Bromodichloromethane & Trichlorofluoromethane & .54 & $<.01$ & 22 \\
\hline Bromodichloromethane & 1,2-Dichloropropane & .59 & $<.01$ & 21 \\
\hline Bromodichloromethane & Tribromomethane & .56 & $<.01$ & 24 \\
\hline 1,4-Dichlorobenzene & 1,2-Dichlorobenzene & .43 & $<.01$ & 272 \\
\hline 1,4-Dichlorobenzene & 1,1,1-Trichloroethane & -.39 & .04 & 30 \\
\hline 1,4-Dichlorobenzene & Ethylbenzene & .46 & $<.01$ & 39 \\
\hline 1,4-Dichlorobenzene & 1,2-Dichloropropane & .52 & $<.01$ & 24 \\
\hline 1,2-Dichlorobenzene & Ethylbenzene & .64 & $<.01$ & 34 \\
\hline 1,2-Dichlorobenzene & Chlorobenzene & .14 & .04 & 208 \\
\hline 1,1-Dichloroethene & Ethylbenzene & .50 & .02 & 21 \\
\hline 1,1-Dichloroethene & Tetrachloromethane & .37 & $<.01$ & 55 \\
\hline 1,1-Dichloroethene & 1,1-Dichloroethane & .37 & .01 & 46 \\
\hline 1,1-Dichloroethene & 1,1,1-Trichloroethane & .58 & $<.01$ & 24 \\
\hline 1,1,1-Trichloroethane & Dibromochloromethane & .48 & $<.01$ & 34 \\
\hline 1,1,1-Trichloroethane & Trichloroethene & .28 & $<.01$ & 96 \\
\hline 1,1,1-Trichloroethane & Tetrachloromethane & .75 & $<.01$ & 28 \\
\hline Dibromochloromethane & 1,1-Dichloroethane & .72 & $<.01$ & 17 \\
\hline Dibromochloromethane & Trichloroethene & .82 & $<.01$ & 44 \\
\hline Trichloroethene & 1,2-Dichloropropane & .44 & $<.01$ & 48 \\
\hline Dibromochloromethane & Trichlorofluoromethane & .61 & $<.01$ & 21 \\
\hline Dibromochloromethane & Tribromomethane & .44 & .03 & 24 \\
\hline
\end{tabular}


Table 6. Volatile organic compounds (VOCs) with significant differences in detections in river-water samples between cooler and warmer months, Ohio River Basin, 1987-96

[IUPAC, International Union of Pure and Applied Chemistry; <, less than]

\begin{tabular}{|c|c|c|c|c|}
\hline \multirow[b]{2}{*}{ IUPAC compound name } & \multicolumn{2}{|c|}{ Number of detections } & \multirow[b]{2}{*}{$\begin{array}{l}\text { Months that had } \\
\text { more detections }\end{array}$} & \multirow[b]{2}{*}{$\begin{array}{c}\text { Rank-sum test } \\
\text { p-value }\end{array}$} \\
\hline & $\begin{array}{c}\text { Cooler months } \\
\text { (October through } \\
\text { March) }\end{array}$ & $\begin{array}{l}\text { Warmer months } \\
\text { (April through } \\
\text { September) }\end{array}$ & & \\
\hline Benzene & 2,890 & 1,615 & cooler & $<0.01$ \\
\hline Methylbenzene & 1,009 & 505 & cooler & .01 \\
\hline Dichloromethane & 911 & 830 & cooler & .01 \\
\hline 1,2-Dichloroethane & 618 & 803 & warmer & $<.01$ \\
\hline Bromodichloromethane & 637 & 701 & warmer & .03 \\
\hline Chlorobenzene & 891 & 313 & cooler & .01 \\
\hline 1,1-Dichloroethene & 478 & 535 & warmer & $<.01$ \\
\hline Trichlorofluoromethane & 89 & 139 & warmer & .01 \\
\hline
\end{tabular}


Table 7. Number of river-water samples from individual Ohio River Valley Water Sanitation Commission (ORSANCO) monitoring stations with detected volatile organic compounds (VOCs), 1987-96

[River miles are from the confluence of the Allegheny and Monongahela Rivers except as indicated; --, not applicable]

\begin{tabular}{|c|c|c|c|c|c|c|}
\hline \multirow{2}{*}{ Station description } & \multicolumn{2}{|c|}{ River miles } & \multirow{2}{*}{$\begin{array}{c}\text { Total } \\
\text { number of } \\
\text { samples }\end{array}$} & \multirow{2}{*}{$\begin{array}{l}\text { Number of } \\
\text { samples } \\
\text { with one or } \\
\text { more VOCs } \\
\text { detected }\end{array}$} & \multirow{2}{*}{$\begin{array}{c}\text { Frequency } \\
\text { of } \\
\text { detection } \\
\text { (percent) }\end{array}$} & \multirow{2}{*}{$\begin{array}{c}\text { Maximum } \\
\text { number of } \\
\text { VOCs } \\
\text { detected in } \\
\text { a sample }\end{array}$} \\
\hline & Ohio River & Tributary & & & & \\
\hline Allegheny River at Pittsburgh, $\mathrm{Pa}$. & -- & 7.4 & 3,549 & 831 & 23 & 7 \\
\hline Monongahela River at Becks Run, Pa. & -- & 4.5 & 3,623 & 2,860 & 79 & 9 \\
\hline Ohio River at Neville Island, $\mathrm{Pa}$. & 4.5 & -- & 3,419 & 474 & 14 & 6 \\
\hline Ohio River at Shippingport, $\mathrm{Pa}$. & 34.9 & -- & 2,190 & 802 & 37 & 7 \\
\hline Ohio River at East Liverpool, Ohio & 40.2 & -- & 1,459 & 981 & 67 & 6 \\
\hline Ohio River at Weirton, W. Va. & 62.5 & -- & 1,957 & 467 & 24 & 10 \\
\hline Ohio River at Wheeling, W. Va. & 86.8 & - & 3,339 & 2,230 & 67 & 8 \\
\hline Ohio River at Parkersburg, W. Va. & 190.3 & -- & 2,804 & 1,110 & 40 & 9 \\
\hline Kanawha River at St. Albans, W. Va. & -- & ${ }^{1} 38.3$ & 2,483 & 1,245 & 50 & 11 \\
\hline Ohio River at Huntington, W. Va. & 306.9 & -- & 3,563 & 1,607 & 45 & 10 \\
\hline Ohio River at Portsmouth, Ohio & 350.7 & -- & 3,213 & 1,059 & 33 & 9 \\
\hline Ohio River at Cincinnati, Ohio & 462.8 & -- & 3,636 & 1,519 & 42 & 8 \\
\hline Ohio River at Louisville, Ky. & 600.6 & -- & 3,624 & 1,349 & 37 & 6 \\
\hline Ohio River at Evansville, Ind. & 791.5 & -- & 3,637 & 2,136 & 59 & 7 \\
\hline Ohio River at Paducah, Ky. & 935.5 & -- & 2,341 & 1,524 & 65 & 5 \\
\hline
\end{tabular}

\footnotetext{
${ }^{1}$ River miles are from the confluence of the Kanawha and Ohio Rivers.
} 
Table 8. Statistical summary of volatile organic compounds (VOCs) in river-water samples from the Ohio River Valley Water Sanitation Commission (ORSANCO) monitoring stations, Ohio River Basin, 1987-96

[IUPAC, International Union of Pure and Applied Chemistry; <, less than; --, not computed]

\begin{tabular}{|c|c|c|c|c|c|c|c|}
\hline \multirow{2}{*}{ IUPAC compound name } & \multirow{2}{*}{$\begin{array}{c}\text { Number of } \\
\text { samples }\end{array}$} & \multirow{2}{*}{$\begin{array}{l}\text { Frequency } \\
\text { of detection } \\
\text { (percent) }\end{array}$} & \multicolumn{5}{|c|}{ Detected concentrations, in micrograms per liter } \\
\hline & & & Mean & $\begin{array}{l}\text { Standard } \\
\text { deviation }\end{array}$ & Median & Minimum & Maximum \\
\hline
\end{tabular}

Allegheny River at Pittsburgh, Pa. (station AR7.40, fig. 1)

\begin{tabular}{|c|c|c|c|c|c|c|}
\hline Trichloromethane & 3,549 & 11.6 & 0.3 & 0.3 & 0.1 & 0.1 \\
\hline Benzene & 3,194 & 2.5 & .2 & .2 & .2 & .1 \\
\hline Methylbenzene & 1,860 & 2.2 & .3 & .2 & .2 & .1 \\
\hline Dichloromethane & 3,549 & 4.9 & .3 & .5 & .2 & .1 \\
\hline 1,3-Dichlorobenzene & 3,194 & .3 & .2 & .1 & .1 & .1 \\
\hline 1,2-Dichloroethane & 3,549 & .1 & .2 & .1 & .1 & .1 \\
\hline Tetrachloroethene & 3,549 & 5.3 & .2 & .3 & .2 & .1 \\
\hline Bromodichloromethane & 3,549 & .8 & .2 & .2 & .1 & .1 \\
\hline 1,4-Dichlorobenzene & 3,194 & .6 & .2 & .1 & .1 & .1 \\
\hline 1,2-Dichlorobenzene & 3,194 & .2 & .1 & .1 & .1 & .1 \\
\hline Chlorobenzene & 3,549 & .1 & .2 & .1 & .1 & .1 \\
\hline 1,1-Dichloroethene & 3,549 & .8 & 1.2 & 1.7 & .6 & .1 \\
\hline 1,1,1-Trichloroethane & 3,549 & 2.0 & .3 & .3 & .3 & .1 \\
\hline Ethylbenzene & 1,860 & .1 & .3 & .1 & .3 & .2 \\
\hline Dibromochloromethane & 3,549 & .8 & .3 & .3 & .1 & .1 \\
\hline Trichloroethene & 3,549 & 1.3 & .5 & .9 & .1 & .1 \\
\hline Tetrachloromethane & 3,549 & .1 & .1 & 0 & .1 & .1 \\
\hline 1,1-Dichloroethane & 3,549 & .1 & .2 & .1 & .2 & .1 \\
\hline Trichlorofluoromethane & 3,549 & .6 & .4 & .4 & .2 & .1 \\
\hline 1,2-Dichloropropane & 3,549 & $<.01$ & .1 & -- & .1 & .1 \\
\hline Tribromomethane & 3,549 & .2 & .1 & 0 & .1 & .1 \\
\hline
\end{tabular}

Monongahela River at Becks Run, Pa. (station MR4.5, fig. 1)

$\begin{array}{lrrrrrrr}\text { Trichloromethane } & 3,623 & 72.0 & 1.3 & 1.4 & 0.8 & 0.1 & .18 .7 \\ \text { Benzene } & 3,277 & 17.5 & .4 & 3.8 & .2 & .1 & 89.0 \\ \text { Methylbenzene } & 1,917 & 10.9 & .1 & .1 & .1 & .1 & 1.2 \\ \text { Dichloromethane } & 3,623 & 7.5 & .4 & .7 & .2 & .1 & 5.5 \\ \text { 1,3-Dichlorobenzene } & 3,277 & .1 & .7 & .6 & .7 & .3 & 1.1 \\ & & & & & & & \\ \text { 1,2-Dichloroethane } & 3,623 & .2 & .5 & .3 & .4 & .2 & .8 \\ \text { Tetrachloroethene } & 3,623 & 6.2 & .5 . & 1.1 & .1 & .1 & 12.2 \\ \text { Bromodichloromethane } & 3,623 & 14.9 & .4 & .4 & .3 & .1 & 3.1 \\ \text { 1,4-Dichlorobenzene } & 3,277 & .1 & .1 & 0 & .1 & .1 & .1 \\ \text { 1,2-Dichlorobenzene } & 3,277 & .1 & .2 & .1 & .2 & .1 & .3 \\ & & & & & & & \\ \text { Chlorobenzene } & 3,623 & .1 & .2 & .1 & .2 & .1 & .3 \\ \text { 1,1-Dichloroethene } & 3,623 & 2.3 & .2 & .3 & .2 & .1 & 2.9 \\ \text { 1,1,1-Trichloroethane } & 3,623 & .6 & .7 & 1.6 & .1 & .1 & 6.8 \\ \text { Ethylbenzene } & 1,917 & .9 & .2 & .2 & .1 & .1 & .9 \\ \text { Dibromochloromethane } & 3,623 & 2.4 & .3 & .2 & .3 & .1 & 1.3\end{array}$


Table 8. Statistical summary of volatile organic compounds (VOCs) in river-water samples from the Ohio River Valley Water Sanitation Commission (ORSANCO) monitoring stations, Ohio River Basin, 1987-96-Continued [IUPAC, International Union of Pure and Applied Chemistry; <, less than; --, not computed]

\begin{tabular}{|c|c|c|c|c|c|c|c|}
\hline \multirow[b]{2}{*}{ IUPAC compound name } & \multirow{2}{*}{$\begin{array}{c}\text { Number of } \\
\text { samples }\end{array}$} & \multirow{2}{*}{$\begin{array}{c}\text { Frequency } \\
\text { of detection } \\
\text { (percent) }\end{array}$} & \multicolumn{5}{|c|}{ Detected concentrations, in micrograms per liter } \\
\hline & & & Mean & $\begin{array}{l}\text { Standard } \\
\text { deviation }\end{array}$ & Median & Minimum & Maximum \\
\hline
\end{tabular}

Monongahela River at Becks Run, Pa. (station MR4.5, fig. 1) - Continued

Trichloroethene

Tetrachloromethane

1,1-Dichloroethane

Trichlorofluoromethane

1,2-Dichloropropane

Tribromomethane

3,623
3,623
3,623
3,623
3,623

3,623

$\begin{array}{rr}0.4 & 0.3 \\ .9 & .1 \\ .1 & .2 \\ 1.0 & .3 \\ .2 & .3\end{array}$

.2

0.4
.1
.1
.2
.1

.2

0.1
.1
.2
.2
.3

6
0.1

.1

.1

.1

.2

.3
1.4

.5

.3

1.2

.4

.8

Ohio River at Neville Island, Pa. (station OR976.50, fig. 1)

Trichloromethane

Benzene

Methylbenzene

Dichloromethane

1,3-Dichlorobenzene

1,2-Dichloroethane

Tetrachloroethene

Bromodichloromethane

1,4-Dichlorobenzene

1,2-Dichlorobenzene

Chlorobenzene

1,1-Dichloroethene

1,1,1-Trichloroethane

Ethylbenzene

Dibromochloromethane

Trichloroethene

Tetrachloromethane

1,1-Dichloroethane

Trichlorofluoromethane

1,2-Dichloropropane

Tribromomethane

$\begin{array}{rrrrrrr}3,419 & 2.5 & 1.0 & 2.2 & 0.2 & 0.1 & 16.6 \\ 3,073 & 7.3 & .2 & .6 & .1 & .1 & 8.8 \\ 1,759 & 1.0 & .2 & .4 & .1 & .1 & 1.6 \\ 3,419 & 1.5 & 2.6 & 2.8 & 1.5 & .1 & 13.4 \\ 3,073 & 2.1 & .2 & .1 & .1 & .1 & .5 \\ 3,419 & <.01 & 1.3 & -- & 1.3 & 1.3 & 1.3 \\ 3,419 & .5 & .6 & .6 & .4 & .1 & 1.8 \\ 3,419 & .6 & 1.9 & 1.6 & 1.8 & .1 & 5.4 \\ 3,073 & 2.1 & .2 & .4 & .1 & .1 & 2.9 \\ 3,073 & 1.6 & .2 & .2 & .1 & .1 & 1.8 \\ 3,419 & .4 & .1 & .1 & .1 & .1 & .4 \\ 3,419 & .3 & 3.8 & 3.5 & 3.1 & .9 & 13.4 \\ 3,419 & .1 & .1 & .1 & .1 & .1 & .2 \\ 1,759 & .2 & .1 & 0 & .1 & .1 & .1 \\ 3,419 & .5 & 1.3 & 1.1 & 1.4 & .1 & 3.6 \\ 3,419 & <.01 & .5 & -- & .5 & .5 & .5 \\ 3,419 & <.01 & .1 & -- & .1 & .1 & .1 \\ 3,419 & <.01 & .2 & -- & .2 & .2 & .2 \\ 3,419 & <.01 & .5 & -- & .5 & .5 & .5 \\ 3,419 & <.01 & 8.2 & -- & 8.2 & 8.2 & 8.2 \\ 3,419 & & & & & & \\ & .2 & .2 & .2 & .1 & .1 & .7\end{array}$

Ohio River at Shippingport, Pa. (station OR946.1, fig. 1)

Trichloromethane

Benzene

Methylbenzene

Dichloromethane

1,3-Dichlorobenzene

1,2-Dichloroethane

Tetrachloroethene

Bromodichloromethane

1,4-Dichlorobenzene

1,2-Dichlorobenzene
2,190

2,190

1,642

2,190

2,190

2,190

2,190

2,190

2,190

2,190
0.1

24.1

17.1

.4

6.7

0

.5

.1

5.4

6.3

$\begin{array}{rr}4.6 & 5.8 \\ .1 & \\ .2 & \\ 2.3 & 2 . \\ .2 & \end{array}$

$5.8 \quad 1.5$

1.0

11.3

2.7

2.2

8.0

1.0

1.2

2.3

.5 
Table 8. Statistical summary of volatile organic compounds (VOCs) in river-water samples from the Ohio River Valley Water Sanitation Commission (ORSANCO) monitoring stations, Ohio River Basin, 1987-96-Continued

[IUPAC, International Union of Pure and Applied Chemistry; <, less than; --, not computed]

\begin{tabular}{lcccc}
\hline IUPAC compound name & Number of & $\begin{array}{c}\text { Frequency } \\
\text { of detection } \\
\text { samples }\end{array}$ & $\begin{array}{c}\text { Detected concentrations, in micrograms per liter } \\
\text { (percent) }\end{array}$ & Mean $\begin{array}{c}\text { Standard } \\
\text { deviation }\end{array}$ Median Minimum Maximum \\
\hline
\end{tabular}

Ohio River at Shippingport, Pa. (station OR946.1, fig. 1) —Continued

\begin{abstract}
Chlorobenzene
1,1-Dichloroethene

1,1,1-Trichloroethane

Ethylbenzene

Dibromochloromethane

Trichloroethene

Tetrachloromethane

1,1-Dichloroethane

Trichlorofluoromethane

1,2-Dichloropropane
\end{abstract}

Tribromomethane
2,190

2,190

2,190

1,642

2,190

2,190

2,190

2,190

2,190

2,190

2,190

0.1
4.7
.8
5.8
0

0.1

.4
9

0

.5

0.1

$\begin{array}{ll}.9 & .6 \\ .1 & 0\end{array}$

1.4

1.0
2.1
0
0

.2

.2

.2

.2

$\begin{array}{ccc}.3 & .3 & .2 \\ 1.8 & .4 & 1.8 \\ .3 & .4 & .2 \\ -- & -- & -- \\ -- & -- & -- \\ & & \\ .2 & .2 & .2\end{array}$

Ohio River at East Liverpool, Ohio (station OR9408, fig.1)

Trichloromethane

Benzene

1,459

32.7

Methylbenzene

Dichloromethane

1,3-Dichlorobenzene

1,2-Dichloroethane

Tetrachloroethene

Bromodichloromethane

1,4-Dichlorobenzene

1,2-Dichlorobenzene

Chlorobenzene

1,1-Dichloroethene

1,1,1-Trichloroethane

Ethylbenzene

Dibromochloromethane

Trichloroethene

Tetrachloromethane

1,1-Dichloroethane

Trichlorofluoromethane

1,2-Dichloropropane

Tribromomethane

Trichloromethane

Benzene

Methylbenzene

Dichloromethane

1,3-Dichlorobenzene
1,282

209

1,459

1,282

37.5

6.7

4.5

8.4

1,459

1,459

1,459

1,282

1,282

1,459

1,459

1,459

209

1,459

1,459

1,459

1,459

1,459

1,459

1,459

.5

15.1

4.1

1.9

$\begin{array}{rlr}0.8 & 1.2 & 0.5 \\ .3 & 1.4 & .1 \\ .1 & 0 & .1 \\ .2 & .3 & .1 \\ .2 & .1 & .1\end{array}$

2.5

.2

.1

.3

1.7

.1

.2

$\begin{array}{rr}0.1 & 9.9 \\ .1 & 18.1 \\ .1 & .1 \\ .1 & 2.1 \\ .1 & 1.0\end{array}$

0.1

0.1

3.2

$\begin{array}{rr}.3 & 2.4 \\ .1 & .3\end{array}$

$1.4 \quad 1.4$

$\begin{array}{cc}.1 & 1.4 \\ 1.5 & 2.0 \\ .1 & 2.6 \\ -- & -- \\ -- & -- \\ & \\ .1 & .5\end{array}$

.5

.5


Table 8. Statistical summary of volatile organic compounds (VOCs) in river-water samples from the Ohio River Valley Water Sanitation Commission (ORSANCO) monitoring stations, Ohio River Basin, 1987-96-Continued

[IUPAC, International Union of Pure and Applied Chemistry; <, less than; --, not computed]

\begin{tabular}{|c|c|c|c|c|c|c|c|}
\hline \multirow[b]{2}{*}{ IUPAC compound name } & \multirow{2}{*}{$\begin{array}{c}\text { Number of } \\
\text { samples }\end{array}$} & \multirow{2}{*}{$\begin{array}{c}\text { Frequency } \\
\text { of detection } \\
\text { (percent) }\end{array}$} & \multicolumn{5}{|c|}{ Detected concentrations, in micrograms per liter } \\
\hline & & & Mean & $\begin{array}{l}\text { Standard } \\
\text { deviation }\end{array}$ & Median & Minimum & Maximum \\
\hline
\end{tabular}

Ohio River at Weirton, W. Va. (station OR9159, fig. 1) - Continued

1,2-Dichloroethane

Tetrachloroethene

Bromodichloromethane

1,4-Dichlorobenzene

1,2-Dichlorobenzene

Chlorobenzene

1,1-Dichloroethene

1,1,1-Trichloroethane

Ethylbenzene

Dibromochloromethane

Trichloroethene

Tetrachloromethane

1,1-Dichloroethane

Trichlorofluoromethane

1,2-Dichloropropane

Tribromomethane

\begin{tabular}{|c|c|c|c|c|c|c|}
\hline 1,957 & 0.1 & 0.1 & -- & 0.1 & 0.1 & 0.1 \\
\hline 1,957 & 1.9 & .9 & 0.5 & .9 & .2 & 2.4 \\
\hline 1,957 & .9 & 1.1 & 2.3 & .4 & .1 & 10.1 \\
\hline 1,957 & 4.5 & .3 & .2 & .2 & .1 & 1.2 \\
\hline 1,957 & 3.2 & .1 & .1 & .1 & .1 & .6 \\
\hline 1,957 & 0 & -- & -- & -- & -- & -- \\
\hline 1,957 & 4.3 & .6 & .3 & .5 & .1 & 1.5 \\
\hline 1,957 & .1 & 3.4 & -- & 3.4 & 3.4 & 3.4 \\
\hline 1,626 & 2.1 & .1 & .1 & .1 & .1 & .5 \\
\hline 1,957 & 1.8 & .7 & .9 & .5 & .1 & 4.0 \\
\hline 1,957 & 2.0 & .6 & .5 & .4 & .1 & 1.6 \\
\hline 1,957 & 0 & -- & -- & -- & -- & -- \\
\hline 1,957 & .6 & 1.0 & .7 & .7 & .1 & 2.4 \\
\hline 1,957 & 0 & -- & -- & -- & -- & -- \\
\hline 1,957 & 1.2 & .2 & .1 & .2 & .1 & .6 \\
\hline 1,957 & .1 & .6 & .5 & .6 & .2 & .9 \\
\hline
\end{tabular}

Ohio River at Wheeling, W. Va. (station OR894.2, fig. 1)

Trichloromethane

Benzene

Methylbenzene

Dichloromethane

1,3-Dichlorobenzene

1,2-Dichloroethane

Tetrachloroethene

Bromodichloromethane

1,4-Dichlorobenzene

1,2-Dichlorobenzene

Chlorobenzene

1,1-Dichloroethene

1,1,1-Trichloroethane

Ethylbenzene

Dibromochloromethane

Trichloroethene

Tetrachloromethane

1,1-Dichloroethane

Trichlorofluoromethane

1,2-Dichloropropane

Tribromomethane
3,339

3,006

1,759

3,339

3,006

3,339

3,339

3,339

3,006

3,006

3,339

3,339

3,339

1,759

3,339

3,339

3,339

3,339

3,339

3,339

3,339
65.0

8.3

7.6

5.3

1.8

$<.01$

5.3

3.9

2.2

2.9

1.3

.2

6.1

.7

1.8

$1.9 \quad .2$

.4

$<.01$

$<.01$

.1

.1

0.6
.5
.2
.2
.2

0.8

1.1

.2

.3

.4

0.4

0.1

11.3

14.8

1.6

2.8

2.8

.1
.2
.1
.3
.2

.1

.5

2.9

1.8

2.0

5.5

2.3

.2

.9

$\begin{array}{llll}.2 & .1 & .1 & 1.3\end{array}$

$\begin{array}{llll}.1 & .1 & .1 & .3\end{array}$

$--\quad .1$

$.2 \quad .1$

$.1 \quad .3$

.1

.3 
Table 8. Statistical summary of volatile organic compounds (VOCs) in river-water samples from the Ohio River Valley Water Sanitation Commission (ORSANCO) monitoring stations, Ohio River Basin, 1987-96-Continued [IUPAC, International Union of Pure and Applied Chemistry; <, less than; --, not computed]

\begin{tabular}{|c|c|c|c|c|c|c|c|}
\hline \multirow[b]{2}{*}{ IUPAC compound name } & \multirow{2}{*}{$\begin{array}{c}\text { Number of } \\
\text { samples }\end{array}$} & \multirow{2}{*}{$\begin{array}{c}\text { Frequency } \\
\text { of detection } \\
\text { (percent) }\end{array}$} & \multicolumn{5}{|c|}{ Detected concentrations, in micrograms per liter } \\
\hline & & & Mean & $\begin{array}{l}\text { Standard } \\
\text { deviation }\end{array}$ & Median & Minimum & Maximum \\
\hline
\end{tabular}

Ohio River at Parkersburg, W. Va. (station OR790.7, fig. 1)

\begin{tabular}{|c|c|c|c|c|c|c|c|}
\hline Trichloromethane & 2,804 & 6.5 & 0.9 & 2.4 & 0.1 & 0.1 & 19.0 \\
\hline Benzene & 2,645 & 7.6 & .2 & .3 & .1 & .1 & 3.1 \\
\hline Methylbenzene & 1,537 & 2.2 & .3 & .4 & .2 & .1 & 2.4 \\
\hline Dichloromethane & 2,804 & 2.6 & .8 & .8 & .5 & .1 & 5.0 \\
\hline 1,3-Dichlorobenzene & 2,645 & 5.4 & .2 & .5 & .1 & .1 & 5.4 \\
\hline 1,2-Dichloroethane & 2,804 & 0 & -- & -- & -- & -- & -- \\
\hline Tetrachloroethene & 2,804 & 1.4 & 1.2 & 2.2 & .3 & .1 & 9.7 \\
\hline Bromodichloromethane & 2,804 & 2.0 & 3.5 & 3.6 & 2.0 & .4 & 18.2 \\
\hline 1,4-Dichlorobenzene & 2,645 & 7.6 & .2 & .2 & .2 & .1 & 1.3 \\
\hline 1,2-Dichlorobenzene & 2,645 & 5.3 & .2 & .4 & .1 & .1 & 3.9 \\
\hline Chlorobenzene & 2,804 & 20.3 & .5 & .6 & .3 & .1 & 9.9 \\
\hline 1,1-Dichloroethene & 2,804 & 9.7 & .9 & 2.0 & .4 & .1 & 22.3 \\
\hline 1,1,1-Trichloroethane & 2,804 & .3 & 1.1 & .7 & .9 & .2 & 2.4 \\
\hline Ethylbenzene & 1,537 & .9 & 3.6 & 12.7 & .2 & .1 & 47.8 \\
\hline Dibromochloromethane & 2,804 & .6 & 1.5 & 1.5 & 1.4 & .1 & 4.5 \\
\hline Trichloroethene & 2,804 & .4 & .4 & .3 & .2 & .1 & 1.1 \\
\hline Tetrachloromethane & 2,804 & .1 & 2.3 & 3.8 & .1 & .1 & 6.6 \\
\hline 1,1-Dichloroethane & 2,804 & .9 & 1.3 & 1.5 & .6 & .1 & 4.5 \\
\hline Trichlorofluoromethane & 2,804 & .1 & 3.0 & 1.2 & 2.6 & 2.1 & 4.6 \\
\hline 1,2-Dichloropropane & 2,804 & .9 & .3 & .5 & .1 & .1 & 1.6 \\
\hline Tribromomethane & 2,804 & .2 & .5 & .3 & .7 & .1 & .8 \\
\hline
\end{tabular}

Kanawha River at St. Albans, W. Va. (station KR38.3, fig. 1)

$\begin{array}{lrrrrrrr}\text { Trichloromethane } & 2,483 & 7.4 & 1.2 & 1.6 & 0.7 & 0.1 & 15.8 \\ \text { Benzene } & 2,389 & 39.0 & .4 & .4 & .2 & .1 & 3.0 \\ \text { Methylbenzene } & 1,253 & 12.4 & .2 & .2 & .1 & .1 & 1.5 \\ \text { Dichloromethane } & 2,483 & 1.1 & 1.5 & 2.1 & .8 & .1 & 8.4 \\ \text { 1,3-Dichlorobenzene } & 2,389 & 9.7 & .5 & 1.4 & .2 & .1 & 15.7 \\ & & & & & & & \\ \text { 1,2-Dichloroethane } & 2,483 & .3 & .3 & .1 & .3 & .1 & .3 \\ \text { Tetrachloroethene } & 2,483 & 1.9 & .7 & 1.1 & .4 & .1 & 7.6 \\ \text { Bromodichloromethane } & 2,483 & 1.4 & 1.7 & 3.4 & .7 & .1 & 15.1 \\ \text { 1,4-Dichlorobenzene } & 2,389 & 9.9 & .6 & 2.9 & .2 & .1 & 42.4 \\ \text { 1,2-Dichlorobenzene } & 2,389 & 4.6 & .4 & .9 & .1 & .1 & 7.0 \\ & & & & & & & \\ \text { Chlorobenzene } & 2,483 & 2.0 & .3 & .3 & .2 & .1 & 1.4 \\ \text { 1,1-Dichloroethene } & 2,483 & 9.2 & 1.1 & 2.5 & .5 & .1 & 31.1 \\ \text { 1,1,1-Trichloroethane } & 2,483 & 1.0 & .3 & .4 & .2 & .1 & 1.6 \\ \text { Ethylbenzene } & 1,253 & 2.4 & .1 & .1 & .1 & .1 & .7 \\ \text { Dibromochloromethane } & 2,483 & 2.0 & 2.8 & 4.9 & .9 & .1 & 20.7\end{array}$


Table 8. Statistical summary of volatile organic compounds (VOCs) in river-water samples from the Ohio River Valley Water Sanitation Commission (ORSANCO) monitoring stations, Ohio River Basin, 1987-96-Continued [IUPAC, International Union of Pure and Applied Chemistry; <, less than; --, not computed]

\begin{tabular}{|c|c|c|c|c|c|c|c|}
\hline \multirow[b]{2}{*}{ IUPAC compound name } & \multirow{2}{*}{$\begin{array}{c}\text { Number of } \\
\text { samples }\end{array}$} & \multirow{2}{*}{$\begin{array}{l}\text { Frequency } \\
\text { of detection } \\
\text { (percent) }\end{array}$} & \multicolumn{5}{|c|}{ Detected concentrations, in micrograms per liter } \\
\hline & & & Mean & $\begin{array}{l}\text { Standard } \\
\text { deviation }\end{array}$ & Median & Minimum & Maximum \\
\hline
\end{tabular}

Kanawha River at St. Albans, W. Va. (station KR38.3, fig. 1) - Continued

Trichloroethene
Tetrachloromethane
1,1-Dichloroethane
Trichlorofluoromethane
1,2-Dichloropropane

Tribromomethane

$\begin{array}{rrrrrrr}2,483 & 3.2 & 0.5 & 0.6 & 0.3 & 0.1 & 3.9 \\ 2,482 & 2.3 & 2.9 & 3.6 & 1.8 & .1 & 19.6 \\ 2,483 & 3.4 & 1.8 & 5.1 & .6 & .1 & 33.2 \\ 2,483 & 1.7 & 3.2 & 3.2 & 2.3 & .1 & 17.0 \\ 2,483 & 2.1 & .4 & .4 & .3 & .1 & 2.9 \\ 2,483 & 1.1 & .4 & .3 & .4 & .1 & .9\end{array}$

Ohio River at Huntington, W. Va. (station OR674.1, fig. 1)

Trichloromethane

Benzene

Methylbenzene

Dichloromethane

1,3-Dichlorobenzene

1,2-Dichloroethane

Tetrachloroethene

Bromodichloromethane

1,4-Dichlorobenzene

1,2-Dichlorobenzene

Chlorobenzene

1,1-Dichloroethene

1,1,1-Trichloroethane

Ethylbenzene

Dibromochloromethane

Trichloroethene

Tetrachloromethane

1,1-Dichloroethane

Trichlorofluoromethane

1,2-Dichloropropane

Tribromomethane

$\begin{array}{rr}3,562 & 26.6 \\ 3,221 & 10.8 \\ 1,899 & 2.6 \\ 3,563 & 2.4 \\ 3,221 & 2.7\end{array}$

3,563

3,563

3,563

3,221

3,221

3,563

3,563

3,563

1,899

3,563

3,563

3,563

3,563

3,563

3,563

3,563

\section{6 \\ 10.8 \\ 2.6 \\ 2.4 \\ 2.7}

.2
2.4

1.6

2.8

4.1

9.2

.9

2.3

1.1

.3

1.7

.5

.4

2.7

.1

.1

$\begin{array}{rr}1.2 & 5.5 \\ .1 & .1 \\ .4 & 1.5 \\ .7 & 1.5 \\ .2 & .2\end{array}$

0.3

.1

0.1

125.3

10.6

8.6

1.5

0

.2

$\begin{array}{rrrr}1.2 & .2 & .1 & 22.0 \\ 25.7 & 2.3 & .1 & 145.4\end{array}$

$\begin{array}{llll}10.1 & .6 & .1 & 84.2\end{array}$

2.2

.2

9.8

2.7

1.1

.9

1.3

3.0

5.4

99.7

20.4

$\begin{array}{rr}6.8 & 24.8 \\ 6.1 & 3.2\end{array}$

$.4 \quad .1$

.3

5.5

.1

.5

4

.7

.8

Ohio River at Portsmouth, Ohio (station OR630.9, fig. 1)

Trichloromethane
Benzene
Methylbenzene
Dichloromethane
1,3-Dichlorobenzene
1,2-Dichloroethane
Tetrachloroethene
Bromodichloromethane
1,4-Dichlorobenzene
1,2-Dichlorobenzene

11.8
9.0
1.5
4.3
1.3

.9

7.1

.5

1.2

2.3
0.3

.1

.1

.1

.2

.2

.2

1.7

.1
3.7

4.3

.2

6.5

23.2

1.3

2.0

9.8

10.3

17.0 
Table 8. Statistical summary of volatile organic compounds (VOCs) in river-water samples from the Ohio River Valley Water Sanitation Commission (ORSANCO) monitoring stations, Ohio River Basin, 1987-96-Continued [IUPAC, International Union of Pure and Applied Chemistry; <, less than; --, not computed]

\begin{tabular}{|c|c|c|c|c|c|c|c|}
\hline \multirow[b]{2}{*}{ IUPAC compound name } & \multirow{2}{*}{$\begin{array}{c}\text { Number of } \\
\text { samples }\end{array}$} & \multirow{2}{*}{$\begin{array}{c}\text { Frequency } \\
\text { of detection } \\
\text { (percent) }\end{array}$} & \multicolumn{5}{|c|}{ Detected concentrations, in micrograms per liter } \\
\hline & & & Mean & $\begin{array}{l}\text { Standard } \\
\text { deviation }\end{array}$ & Median & Minimum & Maximum \\
\hline
\end{tabular}

Ohio River at Portsmouth, Ohio (station OR630.9, fig. 1) - Continued

\begin{tabular}{|c|c|c|c|c|c|c|c|}
\hline Chlorobenzene & 3,213 & 3.4 & 0.1 & 0.1 & 0.1 & 0.1 & 0.5 \\
\hline 1,1-Dichloroethene & 3,213 & 1.1 & .7 & 1.0 & .5 & .1 & 4.9 \\
\hline 1,1,1-Trichloroethane & 3,213 & 1.5 & .3 & .4 & .1 & .1 & 1.7 \\
\hline Ethylbenzene & 1,759 & .5 & 3.1 & 4.3 & 1.0 & .1 & 12.1 \\
\hline Dibromochloromethane & 3,213 & .1 & .5 & .6 & .5 & .1 & .9 \\
\hline Trichloroethene & 3,213 & .3 & .5 & .7 & .2 & .1 & 2.5 \\
\hline Tetrachloromethane & 3,213 & 3.6 & .4 & .4 & .2 & .1 & 1.8 \\
\hline 1,1-Dichloroethane & 3,213 & .8 & 2.0 & 2.4 & 1.5 & .1 & 11.9 \\
\hline Trichlorofluoromethane & 3,213 & 0 & -- & -- & -- & -- & -- \\
\hline 1,2-Dichloropropane & 3,213 & .9 & 3.6 & 3.7 & 2.2 & .1 & 11.0 \\
\hline Tribromomethane & 3,213 & .7 & .3 & .2 & .2 & .1 & .9 \\
\hline
\end{tabular}

Ohio River at Cincinnati, Ohio (station OR518.2, fig. 1)

\begin{tabular}{|c|c|c|c|c|c|c|c|}
\hline Trichloromethane & 3,636 & 34.7 & 0.2 & 0.2 & 0.2 & 0.1 & 2.3 \\
\hline Benzene & 3,271 & 2.8 & .3 & .3 & .2 & .1 & 2.0 \\
\hline Methylbenzene & 1,916 & 1.5 & .2 & .2 & .2 & .1 & .7 \\
\hline Dichloromethane & 3,636 & 2.9 & .3 & .4 & .2 & .1 & 3.2 \\
\hline 1,3-Dichlorobenzene & 3,271 & .2 & .2 & .1 & .2 & .1 & .4 \\
\hline 1,2-Dichloroethane & 3,636 & .4 & .2 & .2 & .1 & .1 & .9 \\
\hline Tetrachloroethene & 3,636 & .6 & .1 & .1 & .1 & .1 & .5 \\
\hline Bromodichloromethane & 3,636 & 4.2 & .1 & .1 & .1 & .1 & .3 \\
\hline 1,4-Dichlorobenzene & 3,271 & .7 & .4 & .6 & .3 & .1 & 2.9 \\
\hline 1,2-Dichlorobenzene & 3,271 & 2.8 & .2 & .1 & .1 & .1 & .6 \\
\hline Chlorobenzene & 3,636 & .5 & .3 & .2 & .2 & .1 & .7 \\
\hline 1,1-Dichloroethene & 3,636 & .5 & .2 & .2 & .2 & .1 & .9 \\
\hline 1,1,1-Trichloroethane & 3,636 & 7.7 & .2 & .2 & .1 & .1 & 2.1 \\
\hline Ethylbenzene & 1,916 & .6 & .1 & 0 & .1 & .1 & .1 \\
\hline Dibromochloromethane & 3,636 & .5 & .1 & .1 & .1 & .1 & .3 \\
\hline Trichloroethene & 3,636 & 1.3 & .2 & .1 & .1 & .1 & .5 \\
\hline Tetrachloromethane & 3,636 & .7 & .1 & .1 & .1 & .1 & .4 \\
\hline 1,1-Dichloroethane & 3,636 & .2 & .2 & .1 & .2 & .1 & .3 \\
\hline Trichlorofluoromethane & 3,636 & .1 & .2 & .1 & .2 & .1 & .2 \\
\hline 1,2-Dichloropropane & 3,636 & .1 & .5 & .3 & .6 & .1 & .7 \\
\hline Tribromomethane & 3,636 & .1 & .3 & .2 & .3 & .1 & 5 \\
\hline
\end{tabular}

Ohio River at Louisville, Ky. (station OR380.4, fig. 1)

Trichloromethane

Benzene

Methylbenzene

Dichloromethane

1,3-Dichlorobenzene

$\begin{array}{rrr}3,624 & 21.4 & 0.1 \\ 3,264 & 1.0 & .2 \\ 1,912 & 1.6 & .1 \\ 3,624 & 6.7 & .3 \\ 3,264 & 1.2 & .2\end{array}$


Table 8. Statistical summary of volatile organic compounds (VOCs) in river-water samples from the Ohio River Valley Water Sanitation Commission (ORSANCO) monitoring stations, Ohio River Basin, 1987-96 - Continued

[IUPAC, International Union of Pure and Applied Chemistry; <, less than; --, not computed]

\begin{tabular}{lccc}
\hline IUPAC compound name & $\begin{array}{c}\text { Number of } \\
\text { samples }\end{array}$ & $\begin{array}{c}\text { Frequency } \\
\text { of detection } \\
\text { (percent) }\end{array}$ & Detected concentrations, in micrograms per liter \\
\cline { 4 - 5 } & $\begin{array}{c}\text { Standard } \\
\text { deviation }\end{array}$ & Median Minimum Maximum \\
\hline
\end{tabular}

Ohio River at Louisville, Ky. (station OR380.4, fig. 1)-Continued

\begin{tabular}{|c|c|c|c|c|c|c|c|}
\hline 1,2-Dichloroethane & 3,624 & 0.9 & 0.5 & 0.3 & 0.4 & 0.1 & 1.2 \\
\hline Tetrachloroethene & 3,624 & 3.0 & .5 & 1.0 & .1 & .1 & 6.3 \\
\hline Bromodichloromethane & 3,624 & .4 & .2 & .2 & .1 & .1 & .6 \\
\hline 1,4-Dichlorobenzene & 3,264 & 1.5 & .2 & .3 & .1 & .1 & 1.7 \\
\hline 1,2-Dichlorobenzene & 3,264 & 1.1 & .3 & .4 & .1 & .1 & 2.0 \\
\hline Chlorobenzene & 3,624 & .8 & .2 & .1 & .2 & .1 & 6 \\
\hline 1,1-Dichloroethene & 3,624 & .3 & .2 & .2 & .1 & .1 & .6 \\
\hline $1,1,1$-Trichloroethane & 3,624 & 1.5 & .2 & .3 & .1 & .1 & 2.4 \\
\hline Ethylbenzene & 1,912 & .5 & .2 & .1 & .2 & .1 & .3 \\
\hline Dibromochloromethane & 3,624 & .7 & .3 & .2 & .1 & .1 & .8 \\
\hline Trichloroethene & 3,624 & .7 & .2 & .1 & .1 & .1 & .7 \\
\hline Tetrachloromethane & 3,624 & .4 & .1 & .1 & .1 & .1 & .4 \\
\hline 1,1-Dichloroethane & 3,624 & .6 & .5 & 6 & .3 & .1 & 2.7 \\
\hline Trichlorofluoromethane & 3,624 & .1 & .6 & .6 & .3 & .1 & 1.3 \\
\hline 1,2-Dichloropropane & 3,624 & .1 & .2 & .1 & .2 & .1 & .3 \\
\hline Tribromomethane & 3,624 & 1.3 & .2 & .2 & .1 & .1 & .8 \\
\hline
\end{tabular}

Ohio River at Evansville, Ind. (station OR189.5, fig. 1)

Trichloromethane

Benzene

Methylbenzene

Dichloromethane

1,3-Dichlorobenzene

1,2-Dichloroethane

Tetrachloroethene

Bromodichloromethane

1,4-Dichlorobenzene

1,2-Dichlorobenzene

Chlorobenzene

1,1-Dichloroethene

1,1,1-Trichloroethane

Ethylbenzene

Dibromochloromethane

Trichloroethene

Tetrachloromethane

1,1-Dichloroethane

Trichlorofluoromethane

1,2-Dichloropropane

Tribromomethane
3,637

3,276

1,915

3,637

3,276

3,637

3,637

3,637

3,276

3,276

3,637

3,637

3,637

1,915

3,637

3,637

3,637

3,637

3,637

3,637

3,637
50.3

10.1

19.0

4.6

8.2

$<.01$

1.2

1.2

4.0

4.7

\section{.8}

.4

.2

2.5

.3

1.2

.1

.4

.1

.5

.1

$\begin{array}{rr}0.3 & 0.5 \\ .1 & .1 \\ .2 & .6 \\ .2 & .1 \\ .1 & .1\end{array}$

0.5
.1
.6
.1
.1

0.2

0.1

10.1

1.0

11.7

1.4

.7

$\begin{array}{llllll}.1 & - & - & .1 & .1 & \end{array}$

.1

.2

.1

.4

1.5

.6

.7

\section{.5}

21.9

.4

.1

1.4

2

6

\section{6}

4

3

8

7
4

.7

8


Table 8. Statistical summary of volatile organic compounds (VOCs) in river-water samples from the Ohio River Valley Water Sanitation Commission (ORSANCO) monitoring stations, Ohio River Basin, 1987-96-Continued [IUPAC, International Union of Pure and Applied Chemistry; <, less than; --, not computed]

\begin{tabular}{|c|c|c|c|c|c|c|c|}
\hline \multirow{2}{*}{ IUPAC compound name } & \multirow{2}{*}{$\begin{array}{c}\text { Number of } \\
\text { samples }\end{array}$} & \multirow{2}{*}{$\begin{array}{l}\text { Frequency } \\
\text { of detection } \\
\text { (percent) }\end{array}$} & \multicolumn{5}{|c|}{ Detected concentrations, in micrograms per liter } \\
\hline & & & Mean & $\begin{array}{l}\text { Standard } \\
\text { deviation }\end{array}$ & Median & Minimum & Maximum \\
\hline \multicolumn{8}{|c|}{ Ohio River at Paducah, Ky. (station (OR45.5, fig. 1) } \\
\hline Trichloromethane & 2,341 & 15.7 & 0.2 & 0.3 & 0.1 & 0.1 & 4.4 \\
\hline Benzene & 2,092 & 1.5 & .1 & 0 & .1 & .1 & .2 \\
\hline Methylbenzene & 780 & 4.0 & .3 & .4 & .1 & .1 & 1.9 \\
\hline Dichloromethane & 2,341 & 3.3 & .3 & .2 & .2 & .1 & 1.7 \\
\hline 1,3-Dichlorobenzene & 2,092 & 2.7 & .5 & .7 & .2 & .1 & 3.8 \\
\hline 1,2-Dichloroethane & 2,341 & 56.0 & 2.5 & 2.9 & 1.5 & .1 & 22.1 \\
\hline Tetrachloroethene & 2,339 & 5.0 & .2 & .2 & .1 & .1 & 2.3 \\
\hline Bromodichloromethane & 2,340 & .3 & .6 & .4 & .5 & .1 & 1.2 \\
\hline 1,4-Dichlorobenzene & 2,092 & 1.1 & .3 & .1 & .2 & .1 & .5 \\
\hline 1,2-Dichlorobenzene & 2,092 & .7 & .3 & .4 & .2 & .1 & 1.3 \\
\hline Chlorobenzene & 2,339 & .1 & .2 & .1 & .2 & .1 & .2 \\
\hline 1,1-Dichloroethene & 2,341 & 3.0 & .4 & .8 & .2 & .1 & 5.1 \\
\hline $1,1,1$-Trichloroethane & 2,341 & .7 & .4 & .4 & .2 & .1 & 1.8 \\
\hline Ethylbenzene & 780 & .4 & .3 & .3 & .2 & .1 & 6 \\
\hline Dibromochloromethane & 2,339 & .2 & .2 & .1 & .3 & .1 & .3 \\
\hline Trichloroethene & 2,339 & .1 & .1 & 0 & .1 & .1 & .1 \\
\hline Tetrachloromethane & 2,341 & .5 & .5 & .9 & .2 & .1 & 3.4 \\
\hline 1,1-Dichloroethane & 2,341 & 1.3 & .2 & .2 & .2 & .1 & .8 \\
\hline Trichlorofluoromethane & 2,341 & .3 & .8 & .5 & .7 & .1 & 1.6 \\
\hline 1,2-Dichloropropane & 2,340 & $<.01$ & .1 & -- & .1 & .1 & .1 \\
\hline Tribromomethane & 2,339 & .2 & .2 & .1 & .2 & .1 & .4 \\
\hline
\end{tabular}


Table 9. Number of samples with volatile organic compound (VOC) pairs detected in river-water samples from individual monitoring stations, Ohio River Basin, 1987-96

[PCODE, U.S. Environmental Protection Agency Storage and Retrieval (STORET) System parameter code; P32106, trichloromethane; P34030, benzene; P78131, methylbenzene; P34423,

dichloromethane; P34566, 1,3-dichlorobenzene; P34531, 1, 2-dichloroethane; P34475, tetrachloroethene; P32101, bromodichloromethane; P34571, 1,4-dichlorobenzene; P34536, 1, 2-dichlorobenzene; P34301, chlorobenzene; P34501, 1,1-dichloroethene; P34506, 1,1,1-trichloroethane; P78113, ethylbenzene; P32105, dibromochloromethane; P39180, trichloroethene; P32102, tetrachloromethane;

P34496, 1,1-dichloroethane; P34488, trichlorofluoromethane; P34541, 1,2-dichloropropane; P32104, tribromomethane; bold numbers indicate percentage of co-occurrences greater than or equal to 20 percent; --, not computed]

\section{Allegheny River at Pittsburgh, Pa. (station AR7.40, fig. 1)}

\begin{tabular}{|c|c|c|c|c|c|c|c|c|c|c|c|c|c|c|c|c|c|c|c|c|c|}
\hline PCODE & P32106 & P34030 & P78131 & P34423 & P34566 & P34531 & P34475 & P32101 & P34571 & P34536 & P34301 & P34501 & P34506 & P78113 & P32105 & P39180 & P32102 & P34496 & P34488 & P34541 & P32104 \\
\hline P32106 & 411 & 12 & 0 & 54 & 1 & 1 & 58 & 24 & 3 & 1 & 0 & 8 & 31 & 0 & 15 & 32 & 1 & 1 & 2 & 0 & 4 \\
\hline P34030 & - & 81 & 0 & 12 & 2 & 0 & 16 & 2 & 4 & 2 & 1 & 1 & 1 & 1 & 2 & 2 & 0 & 0 & 0 & 0 & 0 \\
\hline P78131 & - & -- & 41 & 2 & 0 & 0 & 0 & 0 & 1 & 0 & 0 & 1 & 0 & 1 & 0 & 0 & 0 & 0 & 0 & 0 & 0 \\
\hline P34423 & - & -- & -- & 174 & 1 & 0 & 23 & 10 & 1 & 1 & 0 & 2 & 18 & 0 & 7 & 10 & 0 & 1 & 4 & 0 & 2 \\
\hline P34566 & -- & - & -- & -- & 9 & 1 & 0 & 1 & 2 & 1 & 1 & 0 & 1 & 1 & 1 & 0 & 1 & 0 & 0 & 0 & 0 \\
\hline P34531 & -- & -- & -- & -- & -- & 4 & 1 & 1 & 0 & 0 & 0 & 0 & 1 & 0 & 1 & 0 & 1 & 0 & 0 & 0 & 1 \\
\hline P34475 & -- & - & -- & -- & -- & -- & 189 & 4 & 2 & 2 & 1 & 5 & 17 & 0 & 5 & 20 & 0 & 0 & 9 & 0 & 1 \\
\hline P32101 & -- & -- & -- & -- & -- & -- & -- & 27 & 1 & 0 & 0 & 0 & 2 & 0 & 14 & 1. & 1 & 0 & 0 & 1 & 2 \\
\hline P34571 & - & - & -- & - & -- & -- & -- & - & 20 & 4 & 1 & 1 & 1 & 1 & 1 & 1 & 0 & 0 & 0 & 0 & 0 \\
\hline P34536 & - & - & -- & -- & -- & -- & -- & - & -- & 7 & 1 & 1 & 0 & 1 & 0 & 1 & 0 & 0 & 0 & 0 & 0 \\
\hline P34301 & - & - & -- & -- & -- & -- & -- & -- & -- & -- & 3 & 0 & 0 & 1 & 1 & 0 & 0 & 0 & 0 & 0 & 0 \\
\hline P34501 & - & -- & -- & -- & -- & - & -- & - & -- & -- & -- & 28 & 1 & 0 & 1 & 2 & 0 & 1 & 2 & 0 & 0 \\
\hline P34506 & - & -- & -- & -- & -- & -- & -- & -- & -- & -- & -- & -- & 71 & 0 & 3 & 11 & 1 & 0 & 0 & 0 & 1 \\
\hline P78113. & - & -- & -- & -- & -- & - & -- & -- & -- & -- & -- & -- & -- & 2 & 0 & 0 & 0 & 0 & 0 & 0 & 0 \\
\hline P32105 & - & - & -- & -- & -- & - & -- & -- & -- & -- & -- & -- & -- & - & 27 & 0 & 1 & 0 & 1 & 0 & 2 \\
\hline P39180 & - & - & -- & -- & -- & -- & -- & -- & -- & -- & - & -- & -- & - & - & 47 & 0 & 0 & 0 & 0 & 0 \\
\hline P32102 & -- & -- & -- & -- & -- & - & -- & -- & -- & -- & - & -- & -- & - & - & -- & 2 & 0 & 0 & 0 & 0 \\
\hline P34496 & - & - & -- & -- & - & -- & -- & -- & -- & -- & - & -- & -- & - & - & -- & - & 2 & 1 & 0 & 0 \\
\hline P34488 & - & - & -- & -- & - & -- & -- & -- & -- & - & -- & -- & -- & - & - & -- & - & -- & 21 & 0 & 0 \\
\hline P34541 & -- & -- & - & -- & - & -- & -- & -- & -- & -- & -- & -- & -- & - & -- & -- & -- & -- & -- & 1 & 0 \\
\hline P32104 & -- & -- & - & -- & - & - & -- & -- & -- & - & - & -- & - & - & - & - & - & -- & -- & -- & 7 \\
\hline
\end{tabular}


Table 9. Number of samples with volatile organic compound (VOC) pairs detected in river-water samples from individual monitoring stations, Ohio River Basin, 1987-96-Continued

[PCODE, U.S. Environmental Protection Agency Storage and Retrieval (STORET) System parameter code; P32106, trichloromethane; P34030, benzene; P78131, methylbenzene; P34423,

dichloromethane; P34566, 1,3-dichlorobenzene; P34531, 1, 2-dichloroethane; P34475, tetrachloroethene; P32101, bromodichloromethane; P34571, 1,4-dichlorobenzene; P34536, 1,2-dichlorobenzene; P34301, chlorobenzene; P34501, 1,1-dichloroethene; P34506, 1,1,1-trichloroethane; P78113, ethylbenzene; P32105, dibromochloromethane; P39180, trichloroethene; P32102, tetrachloromethane; P34496, 1,1-dichloroethane; P34488, trichlorofluoromethane; P34541, 1,2-dichloropropane; P32104, tribromomethane; bold numbers indicate percentage of co-occurrences greater than or equal to 20 percent; --, not computed]

Monongahela River at Becks Run, Pa. (station MR4.5, fig. 1)

PCODE P32106 P34030 P78131 P34423 P34566 P34531 P34475 P32101 P34571 P34536 P34301 P34501 P34506 P78113 P32105 P39180 P32102 P34496 P34488 P34541 P32104

\begin{tabular}{|c|c|c|c|c|c|c|c|c|c|c|c|c|c|c|c|c|c|c|c|}
\hline P32106 & 2,607 & 360 & 140 & 254 & 0 & 1 & 213 & 529 & 2 & 3 & 3 & 82 & 17 & 10 & 84 & 12 & 33 & 2 & 35 \\
\hline P34030 & -- & 574 & 189 & 14 & 2 & 0 & 13 & 52 & 2 & 4 & 1 & 1 & 1 & 15 & 7 & 1 & 0 & 1 & 0 \\
\hline P78131 & -- & -- & 208 & 3 & 0 & 0 & 3 & 12 & 0 & 1 & 0 & 0 & 1 & 16 & 3 & 1 & 1 & 1 & 0 \\
\hline P34423 & -- & -- & -- & 270 & 0 & 0 & 139 & 76 & 0 & 0 & 0 & 60 & 13 & 0 & 14 & 7 & 26 & 2 & 2. \\
\hline P34566 & -- & -- & -- & -- & 2 & 0 & 0 & 0 & 0 & 1 & 0 & 0 & 0 & 0 & 0 & 0 & 0 & 0 & ( \\
\hline P34531 & -- & -- & -- & -- & -- & 6 & 1 & 0 & 0 & 0 & 0 & 0 & 0 & 0 & 0 & 0 & 0 & 0 & ( \\
\hline P34475 & -- & -- & -- & -- & -- & -- & 225 & 44 & 0 & 0 & 1 & 58 & 11 & 1 & 10 & 6 & 31 & 1 & 27 \\
\hline P32101 & -- & -- & -- & -- & -- & -- & -- & 540 & 0 & 0 & 0 & 13 & 10 & 0 & 67 & 9 & 8 & 1 & 10 \\
\hline P34571 & - & -- & -- & -- & -- & -- & -- & -- & 2 & 1 & 0 & 0 & 0 & 0 & 0 & 0 & 0 & 0 & ( \\
\hline P34536 & -- & -- & - & -- & -- & -- & - & -- & - & 4 & 0 & 0 & 0 & 0 & 0 & 0 & 0 & 0 & ( \\
\hline P34301 & -- & -- & -- & -- & -- & -- & -- & -- & -- & -- & 3 & 1 & 0 & 0 & 0 & 0 & 1 & 0 & ( \\
\hline P34501 & -- & -- & -- & -- & -- & - & -- & -- & -- & -- & -- & 82 & 6 & 0 & 7 & 2 & 28 & 0 & 2 \\
\hline P34506 & -- & -- & -- & -- & -- & -- & -- & -- & -- & -- & -- & -- & 22 & 0 & 5 & 5 & 3 & 1 & 3 \\
\hline P78113 & -- & - & - & -- & - & -- & -- & -- & -- & -- & -- & -- & -- & 18 & 1 & 0 & 0 & 0 & 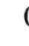 \\
\hline P32105 & -- & -- & -- & -- & -- & -- & -- & -- & -- & -- & -- & - & -- & -- & 86 & 4 & 7 & 1 & , \\
\hline P39180 & -- & -- & -- & -- & -- & -- & -- & -- & -- & -- & -- & -- & -- & -- & -- & 13 & 1 & 1 & \\
\hline P32102 & -- & -- & - & -- & -- & -- & -- & -- & -- & -- & -- & -- & - & -- & -- & -- & 34 & 0 & 2 \\
\hline P34496 & -- & -- & -- & -- & -- & -- & -- & -- & -- & -- & -- & -- & -- & -- & -- & -- & -- & 2 & 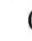 \\
\hline P34488 & -- & -- & -- & -- & - & -- & -- & -- & -- & -- & -- & -- & - & -- & -- & - & -- & -- & 3 \\
\hline P34541 & -- & -- & -- & - & -- & - & -- & -- & -- & -- & -- & -- & -- & -- & -- & - & -- & - & \\
\hline P32104 & -- & -- & -- & -- & -- & -- & -- & -- & 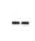 & -- & -- & -- & -- & -- & -- & -- & -- & - & . \\
\hline
\end{tabular}


Table 9. Number of samples with volatile organic compound (VOC) pairs detected in river-water samples from individual monitoring stations, Ohio River Basin, 1987-96-Continued

[PCODE, U.S. Environmental Protection Agency Storage and Retrieval (STTORET) System parameter code; P32106, trichloromethane; P34030, benzene; P78131, methylbenzene; P34423,

dichloromethane; P34566, 1,3-dichlorobenzene; P34531, 1,2-dichloroethane; P34475, tetrachloroethene; P32101, bromodichloromethane; P34571, 1,4-dichlorobenzene; P34536, 1,2-dichlorobenzene; P34301, chlorobenzene; P34501, 1,1-dichloroethene; P34506, 1,1,1-trichloroethane; P781 13, ethylbenzene; P32105, dibromochloromethane; P39180, trichloroethene; P32102, tetrachloromethane;

P34496, 1,1-dichloroethane; P34488, trichlorofluoromethane; P34541, 1,2-dichloropropane; P32104, tribromomethane; bold numbers indicate percentage of co-occurrences greater than or equal to 20 percent; --, not computed]

Ohio River at Neville Island, Pa. (station OR976.50, fig. 1)

PCODE P32106 P34030 P78131 P34423 P34566 P34531 P34475 P32101 P34571 P34536 P34301 P34501 P34506 P78113 P32105 P39180 P32102 P34496 P34488 P34541 P32104

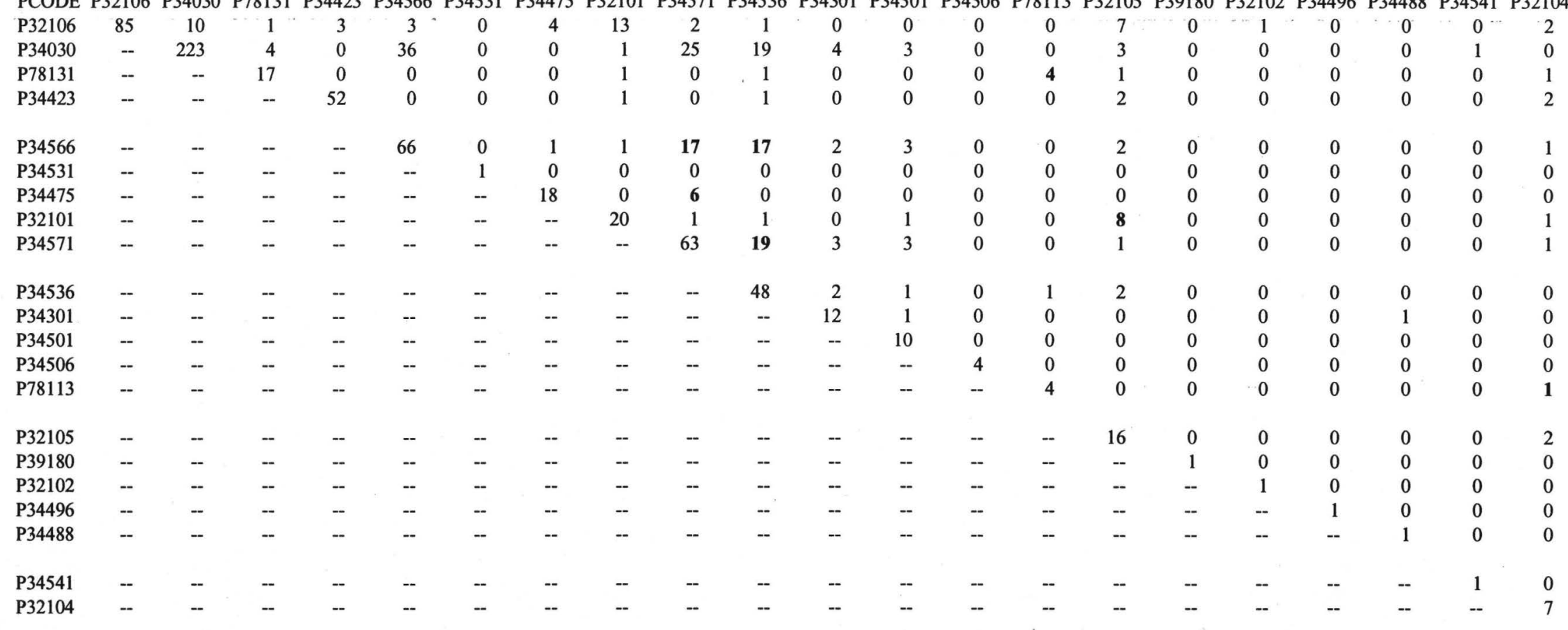


Table 9. Number of samples with volatile organic compound (VOC) pairs detected in river-water samples from individual monitoring stations, Ohio River Basin, 1987-96-Continued

[PCODE, U.S. Environmental Protection Agency Storage and Retrieval (STORET) System parameter code; P32106, trichloromethane; P34030, benzene; P78131, methylbenzene; P34423, dichloromethane; P34566, 1,3-dichlorobenzene; P34531, 1,2-dichloroethane; P34475, tetrachloroethene; P32101, bromodichloromethane; P34571, 1,4-dichlorobenzene; P34536, 1,2-dichlorobenzene; P34301, chlorobenzene; P34501, 1,1-dichloroethene; P34506, 1,1,1-trichloroethane; P78113, ethylbenzene; P32105, dibromochloromethane; P39180, trichloroethene; P32102, tetrachloromethane; P34496, 1,1-dichloroethane; P34488, trichlorofluoromethane; P34541, 1,2-dichloropropane; P32104, tribromomethane; bold numbers indicate percentage of co-occurrences greater than or equal to 20 percent; --, not computed]

Ohio River at Shippingport, Pa. (station OR946.1, fig. 1)

PCODE P32106 P34030 P78131 P34423 P34566 P34531 P34475 P32101 P34571 P34536 P34301 P34501 P34506 P78113 P32105 P39180 P32102 P34496 P34488 P34541 P32104

\begin{tabular}{|c|c|c|c|c|c|c|c|c|c|c|c|c|c|c|c|c|c|c|c|c|}
\hline P32106 & 3 & 1 & 0 & 0 & 0 & 0 & 0 & 1 & 0 & 0 & 0 & 0 & 0 & 0 & 0 & 0 & 0 & 0 & 0 & 0 \\
\hline P34030 & -- & 527 & 227 & 3 & 102 & 0 & 3 & 1 & 87 & 67 & 1 & 44 & 10 & 70 & 0 & 16 & 0 & 13 & 0 & 0 \\
\hline P78131 & -- & -- & 280 & 2 & 77 & 0 & 0 & 0 & 31 & 11 & 0 & 23 & 5 & 84 & 0 & 7 & 1 & 11 & 0 & 0 \\
\hline P34423 & -- & -- & -- & 8 & 2 & 0 & 0 & 0 & 1 & 1 & 0 & 2 & 0 & 2 & 0 & 0 & 0 & 0 & 0 & 0 \\
\hline P34566 & -- & -- & -- & -- & 147 & 0 & 1 & 0 & 42 & 25 & 0 & 15 & 6 & 38 & 0 & 5 & 0 & 5 & 0 & 0 \\
\hline P34531 & -- & -- & -- & -- & -- & -- & -- & -- & -- & -- & -- & -- & -- & -- & -- & -- & -- & -- & -- & -- \\
\hline P34475 & -- & -- & - & -- & -- & -- & 10 & 0 & 0 & 2 & 0 & 0 & 0 & 0 & 0 & 0 & 0 & 0 & 0 & 0 \\
\hline P32101 & -- & -- & -- & -- & -- & -- & -- & 3 & 0 & 0 & 0 & 1 & 0 & 0 & 0 & 0 & 0 & 0 & 0 & 0 \\
\hline P34571 & -- & -- & -- & - & -- & -- & -- & -- & 119 & 35 & 1 & 5 & 3 & 14 & 0 & 2 & 0 & 3 & 0 & 0 \\
\hline P34536 & -- & -- & -- & -- & -- & -- & -- & -- & -- & 137 & 1 & 15 & 0 & 5 & 0 & 3 & 0 & 1 & 0 & 0 \\
\hline P34301 & -- & -- & - & -- & -- & -- & -- & -- & -- & -- & 2 & 0 & 0 & 0 & 0 & 0 & 0 & 0 & 0 & 0 \\
\hline P34501 & -- & -- & -- & -- & -- & -- & -- & -- & -- & -- & -- & 102 & 3 & 9 & 0 & 7 & 0 & 9 & 0 & 0 \\
\hline P34506 & -- & -- & -- & -- & -- & -- & -- & -- & -- & -- & -- & -- & 17 & 2 & 0 & 2 & 0 & 0 & 0 & 0 \\
\hline P78113 & -- & -- & - & -- & -- & -- & -- & -- & -- & -- & -- & -- & -- & 95 & 0 & 2 & 0 & 2 & 0 & 0 \\
\hline P32105 & -- & -- & -- & -- & -- & -- & -- & -- & -- & -- & -- & -- & -- & -- & 1 & 0 & 0 & 0 & 0 & 0 \\
\hline P39180 & - & -- & -- & -- & -- & -- & -- & -- & -- & -- & -- & -- & -- & -- & -- & 21 & 0 & 3 & 0 & 0 \\
\hline P32102 & -- & -- & -- & -- & -- & -- & -- & -- & -- & -- & -- & -- & -- & -- & -- & -- & 2 & 0 & 0 & 0 \\
\hline P34496 & -- & -- & -- & -- & -- & -- & -- & -- & -- & -- & -- & -- & -- & -- & -- & -- & -- & 47 & 0 & 0 \\
\hline P34488 & -- & -- & -- & -- & -- & -- & -- & -- & -- & - & -- & - & - & -- & -- & -- & -- & -- & -- & -- \\
\hline P34541 & -- & -- & -- & -- & -- & -- & -- & -- & -- & -- & -- & -- & -- & -- & -- & -- & -- & -- & -- & -- \\
\hline P32104 & - & -- & -- & -- & -- & -- & -- & -- & -- & -- & -- & -- & - & -- & -- & -- & -- & -- & -- & -- \\
\hline
\end{tabular}


Table 9. Number of samples with volatile organic compound (VOC) pairs detected in river-water samples from individual monitoring stations, Ohio River Basin, 1987-96-Continued

[PCODE, U.S. Environmental Protection Agency Storage and Retrieval (STORET) System parameter code; P32106, trichloromethane; P34030, benzene; P78131, methylbenzene; P34423,

dichloromethane; P34566, 1,3-dichlorobenzene; P34531, 1,2-dichloroethane; P34475, tetrachloroethene; P32101, bromodichloromethane; P34571, 1,4-dichlorobenzene; P34536, 1,2-dichlorobenzene; P34301, chlorobenzene; P34501, 1,1-dichloroethene; P34506, 1,1,1-trichloroethane; P78113, ethylbenzene; P32105, dibromochloromethane; P39180, trichloroethene; P32102, tetrachloromethane;

P34496, 1,1-dichloroethane; P34488, trichlorofluoromethane; P34541, 1,2-dichloropropane; P32104, tribromomethane; bold numbers indicate percentage of co-occurrences greater than or equal to 20 percent; --, not computed]

Ohio River at East Liverpool, Ohio (station OR9408, fig. 1)

PCODE P32106 P34030 P78131 P34423 P34566 P34531 P34475 P32101 P34571 P34536 P34301 P34501 P34506 P78113 P32105 P39180 P32102 P34496 P34488 P34541 P32104

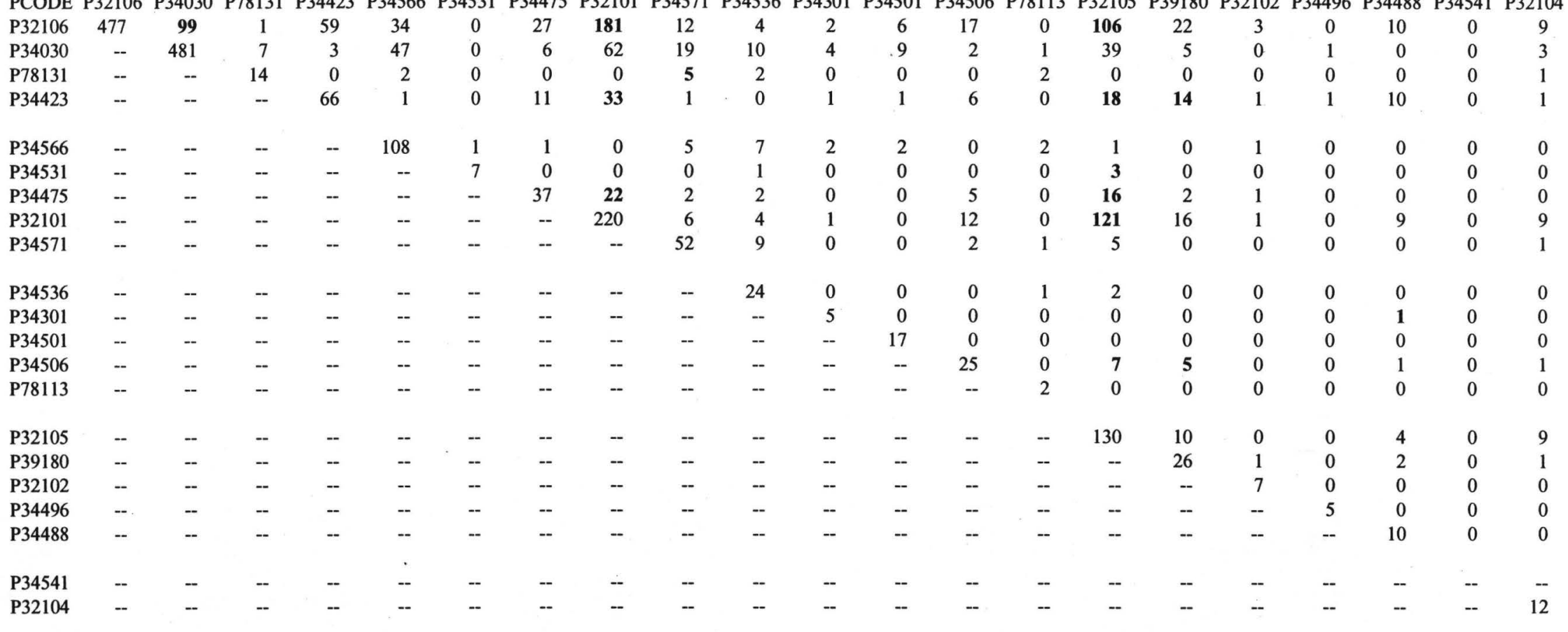


Table 9. Number of samples with volatile organic compound (VOC) pairs detected in river-water samples from individual monitoring stations, Ohio River Basin, 1987-96-Continued

[PCODE, U.S. Environmental Protection Agency Storage and Retrieval (STORET) System parameter code; P32106, trichloromethane; P34030, benzene; P78131, methylbenzene; P34423, dichloromethane; P34566, 1,3-dichlorobenzene; P34531, 1,2-dichloroethane; P34475, tetrachloroethene; P32101, bromodichloromethane; P34571, 1,4-dichlorobenzene; P34536, 1,2-dichlorobenzene; P34301, chlorobenzene; P34501, 1, 1-dichloroethene; P34506, 1,1,1-trichloroethane; P781 13, ethylbenzene; P32105, dibromochloromethane; P39180, trichloroethene; P32102, tetrachloromethane; P34496, 1,1-dichloroethane; P34488, trichlorofluoromethane; P34541, 1,2-dichloropropane; P32104, tribromomethane; bold numbers indicate percentage of co-occurrences greater than or equal to 20 percent; --, not computed]

Ohio River at Weirton, W. Va. (station OR9159, fig. 1)

PCODE P32106 P34030 P78131 P34423 P34566 P34531 P34475 P32101 P34571 P34536 P34301 P34501 P34506 P78113 P32105 P39180 P32102 P34496 P34488 P34541 P32104

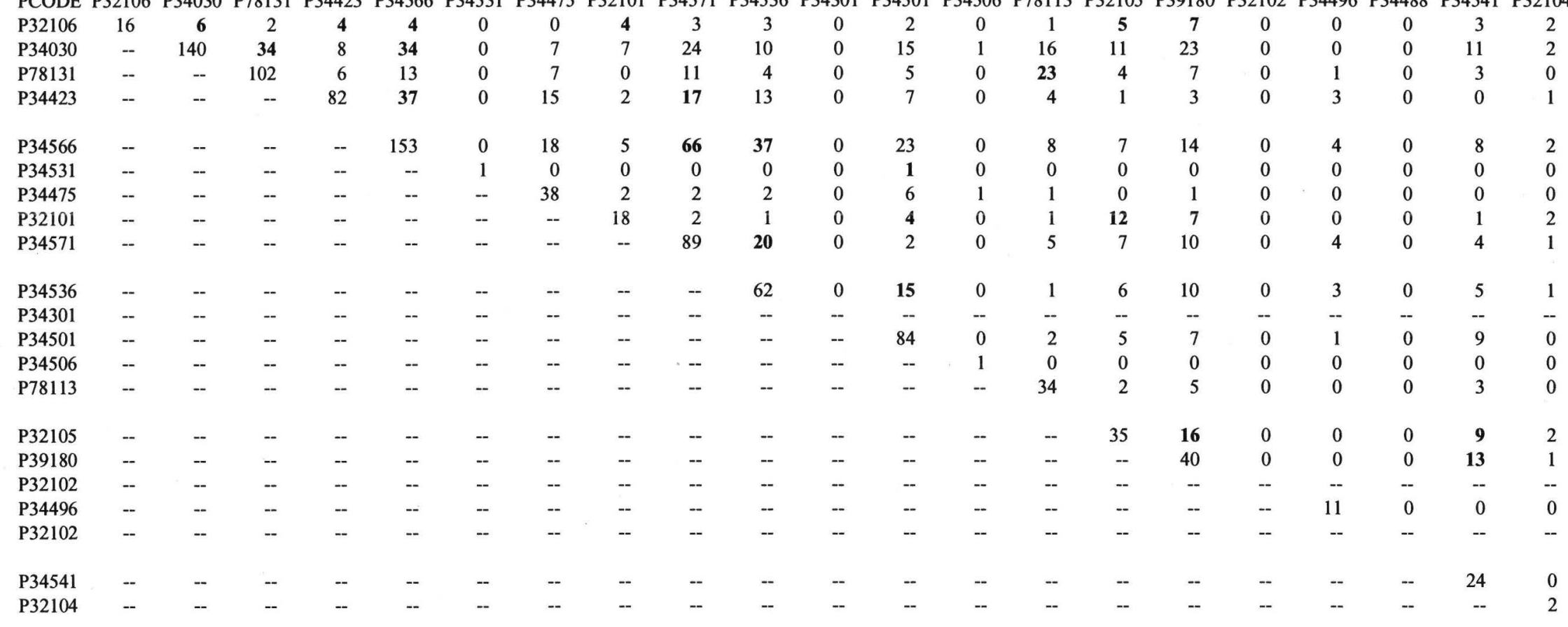


Table 9. Number of samples with volatile organic compound (VOC) pairs detected in river-water samples from individual monitoring stations, Ohio River Basin, 1987-96-Continued

[PCODE, U.S. Environmental Protection Agency Storage and Retrieval (STORET) System parameter code; P32106, trichloromethane; P34030, benzene; P78131, methylbenzene; P34423,

dichloromethane; P34566, 1,3-dichlorobenzene; P34531, 1,2-dichloroethane; P34475, tetrachloroethene; P32101, bromodichloromethane; P34571, 1,4-dichlorobenzene; P34536, 1,2-dichlorobenzene; P34301, chlorobenzene; P34501, 1,1-dichloroethene; P34506, 1,1,1-trichloroethane; P78113, ethylbenzene; P32105, dibromochloromethane; P39180, trichloroethene; P32102, tefrachloromethane;

P34496, 1,1-dichloroethane; P34488, trichlorofluoromethane; P34541, 1,2-dichloropropane; P32104, tribromomethane; bold numbers indicate percentage of co-occurrences greater than or equal to 20 percent; --, not computed]

Ohio River at Wheeling, W. Va. (station OR894.2, fig. 1)

PCODE P32106 P34030 P78131 P34423 P34566 P34531 P34475 P32101 P34571 P34536 P34301 P34501 P34506 P78113 P32105 P39180 P32102 P34496 P34488 P34541 P32104

\begin{tabular}{|c|c|c|c|c|c|c|c|c|c|c|c|c|c|c|c|c|c|c|c|c|c|}
\hline & & & & & & & & & & & & & & & & & & & & & \\
\hline P32106 & 2,172 & 221 & 123 & 172 & 54 & 1 & 172 & 129 & 57 & 81 & 37 & 2 & 199 & 12 & 58 & 64 & 12 & 0 & 1 & 5 & 5 \\
\hline P34030 & - & 251 & 102 & 15 & 11 & 0 & 18 & 1 & 7 & 23 & 5 & 0 & 16 & 11 & 3 & 7 & 0 & 0 & 0 & 0 & 0 \\
\hline P78131 & - & - & 133 & 1 & 11 & 0 & 7 & 1 & 5 & 15 & 2 & 0 & 0 & 11 & 1 & 0 & 0 & 0 & 0 & 0 & 0 \\
\hline P34423 & -- & - & -- & 176 & 10 & 0 & 32 & 13 & 7 & 29 & 3 & 0 & 48 & 1 & 3 & 15 & 1 & 0 & 0 & 0 & 3 \\
\hline P34566 & - & - & -- & -- & 55 & 0 & 10 & 2 & 6 & 10 & 0 & 0 & 4 & 7 & 4 & 1 & 0 & 0 & 0 & 0 & 1 \\
\hline P34531 & -- & -- & - & -- & -- & 1 & 0 & 0 & 0 & 0 & 0 & 0 & 0 & 0 & 0 & 0 & 0 & 0 & 0 & 0 & 0 \\
\hline P34475 & -- & -- & -- & -- & -- & -- & 178 & 33 & 15 & 22 & 17 & 0 & 32 & 0 & 14 & 13 & 1 & 0 & 0 & 1 & 0 \\
\hline P32101 & -- & -- & -- & -- & -- & -- & -- & 130 & 7 & 4 & 9 & 0 & 18 & 0 & 34 & 16 & 1 & 0 & 0 & 1 & 0 \\
\hline P34571 & -- & -- & - & -- & -- & -- & - & - & 65 & 21 & 10 & 0 & 8 & 0 & 2 & 1 & 0 & 0 & 0 & 0 & 0 \\
\hline P34536 & -- & -- & -- & -- & -- & -- & -- & -- & -- & 88 & 8 & 0 & 19 & 3 & 1 & 10 & 0 & 0 & 0 & 0 & 0 \\
\hline P34301 & -- & -- & -- & -- & -- & -- & -- & - & -- & -- & 44 & 0 & 5 & 0 & 4 & 2 & 1 & 0 & 0 & 0 & 0 \\
\hline P34501 & -- & -- & -- & -- & -- & -- & -- & - & -- & -- & - & 8 & 0 & 0 & 0 & 0 & 1 & 0 & 0 & 0 & 1 \\
\hline P34506 & -- & -- & - & -- & -- & -- & -- & - & -- & -- & - & -- & 204 & 0 & 4 & 16 & 2 & 0 & 0 & 1 & 2 \\
\hline P78113 & -- & -- & - & -- & -- & -- & -- & - & -- & -- & - & -- & - & 13 & 0 & 0 & 0 & 0 & 0 & 0 & 0 \\
\hline P32105 & -- & -- & - & -- & -- & -- & - & - & -- & -- & - & -- & -- & -- & 59 & 0 & 0 & 0 & 0 & 0 & 2 \\
\hline P39180 & -- & -- & - & -- & -- & -- & -- & - & -- & -- & - & -- & -- & - & -- & 65 & 3 & 0 & 0 & 0 & 0 \\
\hline P32102 & -- & -- & - & -- & -- & -- & -- & - & -- & -- & - & -- & -- & - & -- & -- & 12 & 0 & 0 & 0 & 1 \\
\hline P34496 & -- & -- & -- & -- & - & -- & -- & - & -- & -- & -- & -- & -- & -- & -- & -- & -- & 1 & 0 & 0 & 0 \\
\hline P34488 & -- & -- & - & -- & -- & - & -- & - & -- & -- & - & -- & -- & -- & -- & -- & - & -- & 1 & 0 & 0 \\
\hline P34541 & -- & -- & - & -- & -- & - & -- & - & -- & -- & -- & -- & -- & - & -- & -- & -- & -- & -- & 5 & 0 \\
\hline P32104 & -- & -- & -- & -- & -- & - & -- & -- & -- & -- & -- & -- & -- & - & -- & -- & - & -- & -- & - & 5 \\
\hline
\end{tabular}


Table 9. Number of samples with volatile organic compound (VOC) pairs detected in river-water samples from individual monitoring stations, Ohio River Basin, 1987-96-Continued

[PCODE, U.S. Environmental Protection Agency Storage and Retrieval (STORET) System parameter code; P32106, trichloromethane; P34030, benzene; P78131, methylbenzene; P34423, dichloromethane; P34566, 1,3-dichlorobenzene; P34531, 1,2-dichloroethane; P34475, tetrachloroethene; P32101, bromodichloromethane; P34571, 1,4-dichlorobenzene; P34536, 1,2-dichlorobenzene; P34301, chlombenzene; P34501, 1,1-dichloroethene; P34506, 1,1,1-trichloroethane; P78113, ethylbenzene; P32105, dibromochloromethane; P39180, trichloroethene; P32102, tetrachloromethane; P34496, 1,1-dichloroethane; P34488, trichlorofluoromethane; P34541, 1,2-dichloropropane; P32104, tribromomethane; bold numbers indicate percentage of co-occurrences greater than or equal to 20 percent; --, not computed]

Ohio River at Parkersburg, W. Va. (station OR790.7, fig. 1)

PCODE P32106 P34030 P78131 P34423 P34566 P34531 P34475 P32101 P34571 P34536 P34301 P34501 P34506 P78113 P32105 P39180 P32102 P34496 P34488 P34541 P32104

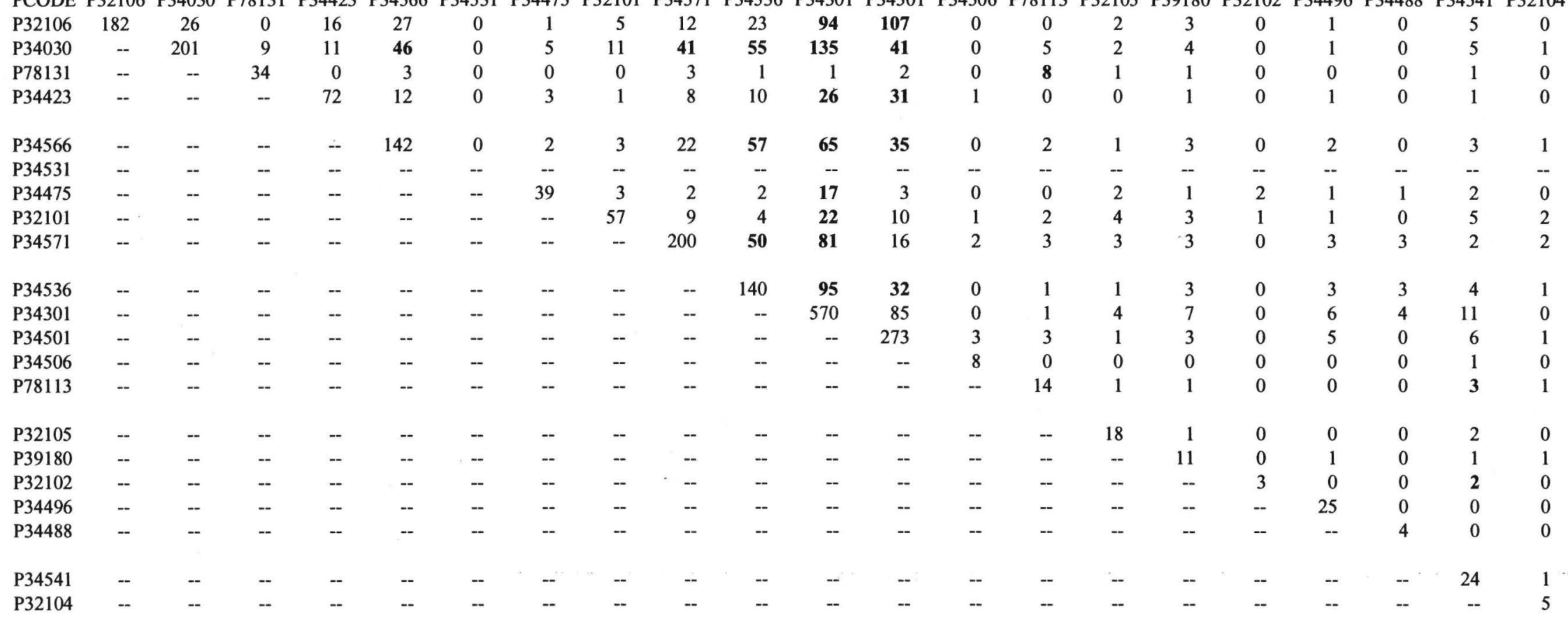


Table 9. Number of samples with volatile organic compound (VOC) pairs detected in river-water samples from individual monitoring stations, Ohio River Basin, 1987-96-Continued

[PCODE, U.S. Environmental Protection Agency Storage and Retrieval (STORET) System parameter code; P32106, trichloromethane; P34030, benzene; P78131, methylbenzene; P34423,

dichloromethane; P34566, 1,3-dichlorobenzene; P34531, 1,2-dichloroethane; P34475, tetrachloroethene; P32101, bromodichloromethane; P34571, 1,4-dichlorobenzene; P34536, 1,2-dichlorobenzene; P34301, chlorobenzene; P34501, 1,1-dichloroethene; P34506, 1,1,1-trichloroethane; P78113, ethylbenzene; P32105, dibromochloromethane; P39180, trichloroethene; P32102, tetrachloromethane; P34496, 1,1-dichloroethane; P34488, trichlorofluoromethane; P34541, 1,2-dichloropropane; P32104, tribromomethane; bold numbers indicate percentage of co-occurrences greater than or equal to 20 percent; --, not computed]

Kanawha River at St. Albans, W. Va. (station KR38.3, fig. 1)

PCODE P32106 P34030 P78131 P34423 P34566 P34531 P34475 P32101 P34571 P34536 P34301 P34501 P34506 P78113 P32105 P39180 P32102 P34496 P34488 P34541 P32104

\begin{tabular}{|c|c|c|c|c|c|c|c|c|c|c|c|c|c|c|c|c|c|c|c|c|c|}
\hline & & & & & & & & & & & & & & & & & & & & & \\
\hline P32106 & 184 & 112 & 16 & 11 & 52 & 1 & 17 & 11 & 52 & 19 & 8 & 45 & 10 & 5 & 10 & 26 & 6 & 7 & 1 & 26 & 15 \\
\hline P34030 & - & 931 & 124 & 16 & 187 & 4 & 29 & 21 & 177 & 89 & 46 & 175 & 14 & 22 & 16 & 54 & 39 & 32 & 27 & 40 & 19 \\
\hline P78131 & -- & - & 155 & 5 & 34 & 0 & 4 & 4 & 51 & 26 & 2 & 23 & 3 & 24 & 2 & 6 & 6 & 5 & 0 & 3 & 2 \\
\hline P34423 & -- & - & -- & 28 & 9 & 0 & 3 & 2 & 4 & 1 & 0 & 7 & 4 & 0 & 1 & 9 & 0 & 0 & 0 & 4 & 3 \\
\hline P34566 & -- & -- & -- & -- & 232 & 2 & 21 & 8 & 60 & 58 & 23 & 65 & 10 & 6 & 10 & 34 & 13 & 12 & 9 & 25 & 12 \\
\hline P34531 & -- & -- & -- & -- & -- & 8 & 0 & 1 & 0 & 0 & 0 & 1 & 0 & 0 & 0 & 1 & 0 & 0 & 0 & 0 & 1 \\
\hline P34475 & -- & -- & -- & -- & -- & -- & 46 & 3 & 12 & 6 & 7 & 20 & 3 & 2 & 4 & 8 & 4 & 2 & 1 & 7 & 2 \\
\hline P32101 & -- & -- & -- & -- & -- & -- & -- & 35 & 6 & 0 & 2 & 8 & 6 & 1 & 2 & 9 & 3 & 3 & 2 & 10 & 5 \\
\hline P34571 & -- & - & -- & -- & -- & -- & -- & -- & 236 & 45 & 14 & 46 & 7 & 7 & 6 & 23 & 11 & 16 & 7 & 16 & 8 \\
\hline P34536 & -- & - & - & -- & -- & -- & -- & - & -- & 111 & 18 & 29 & 2 & 6 & 1 & 7 & 2 & 4 & 1 & 13 & 3 \\
\hline P34301 & - & -- & -- & -- & -- & -- & -- & -- & -- & -- & 49 & 17 & 0 & 3 & 2 & 5 & 0 & 2 & 1 & 6 & 2 \\
\hline P34501 & -- & -- & -- & -- & -- & -- & -- & -- & -- & -- & -- & 229 & 6 & 6 & 7 & 16 & 18 & 19 & 1 & 19 & 10 \\
\hline P34506 & -- & - & -- & -- & -- & - & -- & -- & -- & -- & -- & - & 24 & 0 & 2 & 6 & 0 & 0 & 0 & 9 & 3 \\
\hline P78113 & -- & - & -- & -- & -- & -- & -- & - & -- & - & - & -- & -- & 30 & 1 & 1 & 0 & 0 & 0 & 0 & 1 \\
\hline P32105 & -- & -- & -- & -- & -- & -- & -- & -- & -- & -- & -- & -- & -- & -- & 50 & 8 & 4 & 12 & 9 & 4 & 3 \\
\hline P39180 & - & -- & -- & -- & -- & -- & -- & -- & -- & -- & - & -- & -- & -- & -- & 79 & 6 & 5 & 0 & 23 & 6 \\
\hline P32102 & - & -- & -- & -- & -- & - & -- & -- & -- & -- & -- & -- & -- & -- & -- & -- & 56 & 15 & 1 & 3 & 3 \\
\hline P34496 & - & -- & -- & -- & -- & - & -- & -- & -- & -- & -- & -- & -- & -- & - & -- & -- & 85 & 7 & 1 & 2 \\
\hline P34488 & - & - & -- & -- & - & - & - & -- & -- & -- & - & -- & -- & -- & - & -- & -- & - & 43 & 0 & 2 \\
\hline P34541 & -- & -- & -- & -- & -- & - & -- & -- & -- & - & - & -- & -- & -- & -- & -- & -- & -- & - & 52 & 5 \\
\hline P32104 & -- & -- & -- & -- & -- & - & -- & -- & -- & -- & - & -- & -- & -- & - & -- & -- & -- & -- & -- & 28 \\
\hline
\end{tabular}


Table 9. Number of samples with volatile organic compound (VOC) pairs detected in river-water samples from individual monitoring stations, Ohio River Basin, 1987-96-Continued

[PCODE, U.S. Environmental Protection Agency Storage and Retrieval (STORET) System parameter code; P32106, trichloromethane; P34030, benzene; P78131, methylbenzene; P34423, dichloromethane; P34566, 1,3-dichlorobenzene; P34531, 1,2-dichloroethane; P34475, tetrachloroethene; P32101, bromodichloromethane; P34571, 1,4-dichlorobenzene; P34536, 1,2-dichlorobenzene; P34301, chlorobenzene; P34501, 1,1-dichloroethene; P34506, 1,1,1-trichloroethane; P78113, ethylbenzene; P32105, dibromochloromethane; P39180, trichloroethene; P32102, tetrachloromethane; P34496, 1,1-dichloroethane; P34488, trichlorofluoromethane; P34541, 1,2-dichloropropane; P32104, tribromomethane; bold numbers indicate percentage of co-occurrences greater than or equal to 20 percent; --, not computed]

Ohio River at Huntington, W. Va. (station OR674.1, fig. 1)

PCODE P32106 P34030 P78131 P34423 P34566 P34531 P34475 P32101 P34571 P34536 P34301 P34501 P34506 P78113 P32105 P39180 P32102 P34496 P34488 P34541 P32104

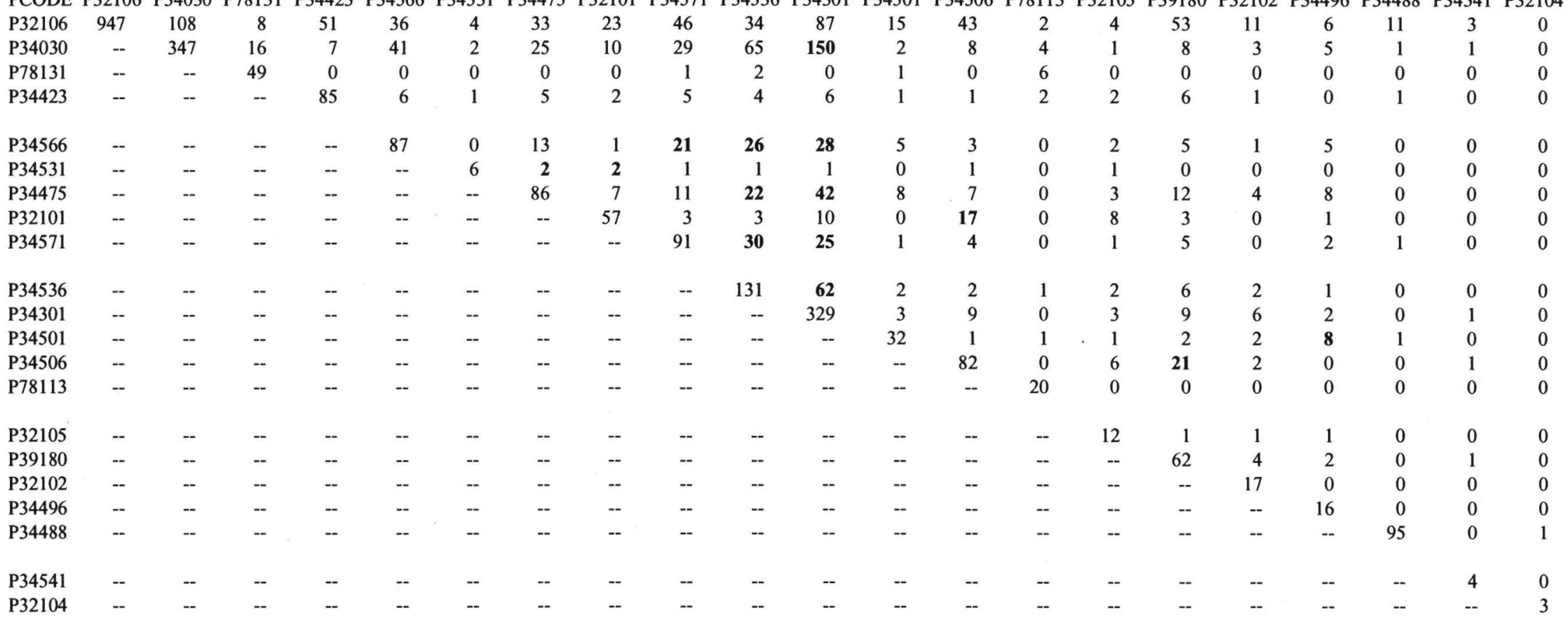


Table 9. Number of samples with volatile organic compound (VOC) pairs detected in river-water samples from individual monitoring stations, Ohio River Basin, 1987-96-Continued

[PCODE, U.S. Environmental Protection Agency Storage and Retrieval (STORET) System parameter code; P32106, trichloromethane; P34030, benzene; P78131, methylbenzene; P34423, dichloromethane; P34566, 1,3-dichlorobenzene; P34531, 1,2-dichloroethane; P34475, tetrachloroethene; P32101, bromodichloromethane; P34571, 1,4-dichlorobenzene; P34536, 1,2-dichlorobenzene; P34301, chlorobenzene; P34501, 1,1-dichloroethene; P34506, 1,1,1-trichloroethane; P78113, ethylbenzene; P32105, dibromochloromethane; P39180, trichloroethene; P32102, tetrachloromethane; P34496, 1,1-dichloroethane; P34488, trichlorofluoromethane; P34541, 1,2-dichloropropane; P32104, tribromomethane; bold numbers indicate percentage of co-occurrences greater than or equal to 20 percent; --, not computed]

Ohio River at Portsmouth, Ohio (station OR630.9, fig. 1)

PCODE P32106 P34030 P78131 P34423 P34566 P34531 P34475 P32101 P34571 P34536 P34301 P34501 P34506 P78113 P32105 P39180 P32102 P34496 P34488 P34541 P32104

\begin{tabular}{|c|c|c|c|c|c|c|c|c|c|c|c|c|c|c|c|c|c|c|c|c|c|}
\hline & & & & & & & & & & & & & & & & & & & & & \\
\hline P32106 & 380 & 18 & 0 & 114 & 0 & 26 & 108 & 1 & 0 & 1 & 2 & 1 & 28 & 0 & 1 & 3 & 2 & 2 & 0 & 0 & 8 \\
\hline P34030 & - & 261 & 22 & 5 & 5 & 0 & 46 & 0 & 11 & 20 & 24 & 1 & 1 & 2 & 0 & 1 & 27 & 1 & 0 & 4 & 0 \\
\hline P78131 & - & -- & 26 & 0 & 2 & 0 & 5 & 0 & 3 & 2 & 1 & 0 & 0 & 2 & 0 & 1 & 12 & 0 & 0 & 1 & 0 \\
\hline P34423 & -- & -- & -- & 138 & 0 & 4 & 76 & 0 & 0 & 0 & 1 & 5 & 19 & 0 & 1 & 2 & 2 & 1 & 0 & 2 & 4 \\
\hline P34566 & -- & - & -- & -- & 37 & 0 & 6 & 1 & 8 & 12 & 5 & 0 & 0 & 6 & 0 & 1 & 2 & 0 & 0 & 3 & 1 \\
\hline P34531 & -- & -- & -- & -- & -- & 30 & 4 & 0 & 0 & 0 & 0 & 1 & 1 & 0 & 0 & 0 & 0 & 0 & 0 & 0 & 0 \\
\hline P34475 & - & - & -- & -- & -- & -- & 229 & 0 & 6 & 10 & 4 & 0 & 24 & 1 & 1 & 4 & 12 & 1 & 0 & 8 & 9 \\
\hline P32101 & -- & - & -- & -- & -- & - & -- & 15 & 1 & 1 & 0 & 0 & 0 & 0 & 0 & 0 & 2 & 1 & 0 & 2 & 0 \\
\hline P34571 & -- & - & - & -- & -- & -- & -- & - & 35 & 8 & 6 & 0 & 0 & 4 & 0 & 1 & 3 & 0 & 0 & 2 & 0 \\
\hline P34536 & -- & - & -- & -- & -- & -- & -- & - & -- & 67 & 10 & 0 & 0 & 3 & 0 & 1 & 5 & 0 & 0 & 3 & 2 \\
\hline P34301 & -- & -- & -- & -- & -- & -- & -- & -- & -- & -- & 109 & 0 & 0 & 2 & 0 & 1 & 0 & 0 & 0 & 2 & 0 \\
\hline P34501 & -- & -- & - & -- & -- & -- & -- & - & -- & -- & -- & 35 & 0 & 0 & 0 & 0 & 1 & 3 & 0 & 1 & 1 \\
\hline P34506 & -- & -- & - & -- & -- & - & -- & - & -- & -- & -- & - & 49 & 0 & 1 & 2 & 1 & 0 & 0 & 0 & 4 \\
\hline P78113 & -- & -- & -- & -- & -- & -- & -- & - & -- & -- & -- & -- & -- & 9 & 0 & 1 & 2 & 0 & 0 & 1 & 1 \\
\hline P32105 & - & -- & -- & -- & -- & - & -- & - & -- & -- & - & -- & -- & -- & 2 & 0 & 0 & 0 & 0 & 0 & 0 \\
\hline P39180 & -- & -- & -- & -- & -- & -- & -- & -- & -- & -- & -- & -- & -- & - & -- & 10 & 0 & 0 & 0 & 1 & 0 \\
\hline P32102 & -- & - & - & -- & -- & -- & -- & - & -- & -- & -- & -- & -- & -- & -- & -- & 116 & 0 & 0 & 1 & 2 \\
\hline P34496 & -- & -- & -- & -- & -- & -- & -- & - & -- & -- & -- & -- & -- & -- & -- & -- & -- & 27 & 0 & 1 & 0 \\
\hline P34488 & -- & -- & - & -- & -- & -- & -- & - & -- & -- & -- & -- & -- & -- & -- & -- & -- & -- & -- & -- & - \\
\hline P34541 & -- & - & -- & -- & -- & -- & -- & - & -- & -- & -- & -- & -- & -- & -- & - & -- & -- & -- & 30 & 1 \\
\hline P32104 & - & -- & -- & -- & -- & -- & -- & - & -- & -- & -- & -- & -- & - & -- & -- & - & -- & -- & - & 24 \\
\hline
\end{tabular}


Table 9. Number of samples with volatile organic compound (VOC) pairs detected in river-water samples from individual monitoring stations, Ohio River Basin, 1987-96-Continued

[PCODE, U.S. Environmental Protection Agency Storage and Retrieval (STORET) System parameter code; P32106, trichloromethane; P34030, benzene; P78131, methylbenzene; P34423,

dichloromethane; P34566, 1,3-dichlorobenzene; P34531, 1,2-dichloroethane; P34475, tetrachloroethene; P32101, bromodichloromethane; P34571, 1,4-dichlorobenzene; P34536, 1,2-dichlorobenzene;

P34301, chlorobenzene; P34501, 1,1-dichloroethene; P34506, 1, 1,1-trichloroethane; P78113, ethylbenzene; P32105, dibromochloromethane; P39180, trichloroethene; P32102, tetrachloromethane;

P34496, 1,1-dichloroethane; P34488, trichlorofluoromethane; P34541, 1,2-dichloropropane; P32104, tribromomethane; bold numbers indicate percentage of co-occurrences greater than or equal to 20 percent; --, not computed]

Ohio River at Cincinnati, Ohio (station OR518.2, fig. 1)

PCODE P32106 P34030 P78131 P34423 P34566 P34531 P34475 P32101 P34571 P34536 P34301 P34501 P34506 P78113 P32105 P39180 P32102 P34496 P34488 P34541 P32104

\begin{tabular}{|c|c|c|c|c|c|c|c|c|c|c|c|c|c|c|c|c|c|c|c|c|c|}
\hline & & & & & & & & & & & & & & & & & & & & & \\
\hline P32106 & 1,263 & 31 & 0 & 73 & 6 & 7 & 16 & 150 & 19 & 47 & 13 & 8 & 229 & 1 & 13 & 38 & 24 & 5 & 0 & 1 & 1 \\
\hline P34030 & -- & 93 & 3 & 5 & 2 & 0 & 5 & 7 & 5 & 6 & 7 & 0 & 11 & 0 & 0 & 4 & 1 & 1 & 0 & 0 & 0 \\
\hline P78131 & -- & -- & 29 & 0 & 0 & 0 & 0 & 0 & 0 & 1 & 0 & 0 & 0 & 0 & 0 & 0 & 0 & 0 & 0 & 0 & 0 \\
\hline P34423 & -- & -- & -- & 105 & 1 & 2 & 3 & 13 & 3 & 6 & 5 & 2 & 15 & 0 & 1 & 8 & 3 & 2 & 0 & 0 & 1 \\
\hline P34566 & -- & -- & -- & -- & 7 & 0 & 0 & 0 & 2 & 0 & 1 & 0 & 1 & 0 & 0 & 1 & 0 & 0 & 0 & 0 & 0 \\
\hline P34531 & -- & -- & -- & -- & -- & 13 & 1 & 1 & 1 & 0 & 0 & 0 & 4 & 0 & 1 & 3 & 1 & 0 & 0 & 0 & 0 \\
\hline P34475 & -- & -- & -- & -- & -- & -- & 22 & 4 & 0 & 0 & 0 & 0 & 9 & 0 & 2 & 5 & 4 & 1 & 0 & 0 & 0 \\
\hline P32101 & -- & -- & -- & -- & -- & - & -- & 153 & 2 & 4 & 4 & 2 & 63 & 0 & 8 & 9 & 12 & 2 & 0 & 0 & 1 \\
\hline P34571 & -- & -- & -- & - & -- & -- & -- & -- & 24 & 3 & 4 & 0 & 2 & 0 & 0 & 2 & 0 & 0 & 0 & 0 & 0 \\
\hline P34536 & -- & -- & -- & -- & -- & -- & -- & -- & -- & 90 & 3 & 0 & 8 & 0 & 0 & 4 & 0 & 0 & 0 & 0 & 0 \\
\hline P34301 & -- & -- & -- & -- & -- & -- & -- & -- & -- & -- & 18 & 0 & 4 & 0 & 1 & 2 & 0 & 0 & 0 & 0 & 0 \\
\hline P34501 & -- & -- & -- & -- & -- & -- & -- & -- & -- & -- & -- & 17 & 2 & 0 & 0 & 0 & 2 & 0 & 0 & 0 & 0 \\
\hline P34506 & -- & -- & -- & -- & -- & -- & -- & -- & -- & -- & -- & -- & 281 & 1 & 4 & 25 & 18 & 1 & 0 & 0 & 0 \\
\hline P78113 & -- & -- & -- & -- & -- & -- & -- & -- & -- & -- & -- & -- & -- & 11 & 0 & 0 & 0 & 0 & 0 & 0 & 0 \\
\hline P32105 & -- & -- & -- & -- & -- & -- & -- & -- & -- & -- & -- & -- & -- & -- & 19 & 3 & 1 & 0 & 0 & 0 & 0 \\
\hline P39180 & -- & -- & . -- & -- & -- & -- & -- & -- & -- & -- & -- & -- & -- & -- & - & 46 & 3 & 1 & 0 & 0 & 0 \\
\hline P32102 & -- & -- & -- & -- & -- & -- & -- & -- & -- & -- & -- & -- & -- & -- & - & -- & 25 & 1 & 0 & 0 & 0 \\
\hline P34496 & -- & -- & -- & -- & -- & -- & -- & -- & -- & -- & -- & -- & -- & -- & - & -- & -- & 7 & 0 & 0 & 0 \\
\hline P34488 & -- & -- & -- & -- & -- & -- & -- & -- & -- & -- & -- & -- & -- & -- & - & - & -- & -- & 2 & 0 & 0 \\
\hline P34541 & - & -- & - & - & -- & -- & -- & - & -- & -- & -- & -- & -- & -- & -- & -- & -- & -- & -- & 3 & 0 \\
\hline P32104 & -- & -- & - & -- & -- & -- & -- & -- & -- & -- & - & -- & -- & -- & -- & -- & - & -- & -- & -- & 3 \\
\hline
\end{tabular}


Table 9. Number of samples with volatile organic compound (VOC) pairs detected in river-water samples from individual monitoring stations, Ohio River Basin, 1987-96-Continued

[PCODE, U.S. Environmental Protection Agency Storage and Retrieval (STORET) System parameter code; P32106, trichloromethane; P34030, benzene; P78131, methylbenzene; P34423,

dichloromethane; P34566, 1,3-dichlorobenzene; P34531, 1,2-dichloroethane; P34475, tetrachloroethene; P32101, bromodichloromethane; P34571, 1,4-dichlorobenzene; P34536, 1,2-dichlorobenzene; P34301, chlorobenzene; P34501, 1,1-dichloroethene; P34506, 1,1,1-trichloroethane; P78113, ethylbenzene; P32105, dibromochloromethane; P39180, trichloroethene; P32102, tetrachloromethane;

P34496, 1,1-dichloroethane; P34488, trichlorofluoromethane; P34541, 1,2-dichloropropane; P32104, tribromomethane; bold numbers indicate percentage of co-occurrences greater than or equal to 20 percent; --, not computed]

Ohio River at Louisville, Ky. (station OR380.4, fig. 1)

PCODE P32106 P34030 P78131 P34423 P34566 P34531 P34475 P32101 P34571 P34536 P34301 P34501 P34506 P78113 P32105 P39180 P32102 P34496 P34488 P34541 P32104

\begin{tabular}{|c|c|c|c|c|c|c|c|c|c|c|c|c|c|c|c|c|c|c|c|c|}
\hline \multirow{2}{*}{$\begin{array}{l}\text { P32106 } \\
\text { P34030 }\end{array}$} & 775 & 8 & 5 & 76 & 3 & 3 & 31 & 5 & 9 & 5 & 7 & 1 & 5 & 2 & 3 & 1 & 3 & 1 & 2 & \multirow{2}{*}{0} \\
\hline & -- & 34 & 4 & 3 & 0 & 0 & 0 & 1 & 0 & 0 & 1 & 0 & 0 & 5 & 0 & 0 & 0 & 0 & 0 & \\
\hline P78131 & -- & - & 31 & 0 & 2 & 2 & 2 & 0 & 1 & 0 & 0 & 0 & 0 & 2 & 2 & 0 & 0 & 1 & 0 & 0 \\
\hline P34423 & -- & - & -- & 241 & 2 & 2 & 11 & 3 & 5 & 7 & 8 & 2 & 7 & 1 & 4 & 1 & 6 & 3 & 1 & 0 \\
\hline P34566 & -- & - & -- & -- & 38 & 1 & 7 & 1 & 4 & 2 & 4 & 0 & 0 & 0 & 2 & 1 & 0 & 0 & 0 & 0 \\
\hline P34531 & -- & - & -- & -- & -- & 31 & 5 & 0 & 1 & 3 & 0 & 0 & 3 & 1 & 5 & 1 & 1 & 2 & 0 & 1 \\
\hline P34475 & -- & -- & - & -- & -- & -- & 109 & 1 & 9 & 6 & 2 & 1 & 2 & 0 & 2 & 2 & 0 & 3 & 0 & 0 \\
\hline P32101 & -- & -- & -- & -- & -- & -- & -- & 15 & 2 & 0 & 1 & 0 & 0 & 0 & 2 & 0 & 1 & 1 & 1 & 0 \\
\hline P34571 & -- & -- & -- & -- & -- & -- & -- & -- & 49 & 7 & 3 & 2 & 0 & 0 & 1 & 0 & 0 & 2 & 0 & 0 \\
\hline P34536 & -- & -- & -- & -- & -- & -- & -- & -- & - & 35 & 5 & 1 & 0 & 0 & 1 & 2 & 1 & 0 & 0 & 0 \\
\hline P34301 & -- & -- & -- & -- & -- & -- & -- & -- & - & -- & 29 & 0 & 1 & 0 & 1 & 1 & 0 & 0 & 0 & 0 \\
\hline P34501 & - & - & - & -- & -- & -- & -- & -- & - & -- & -- & 12 & 2 & 0 & 0 & 0 & 1 & 0 & 0 & 0 \\
\hline P34506 & -- & - & -- & -- & -- & -- & -- & - & - & -- & -- & - & 56 & 0 & 2 & 2 & 1 & 2 & 1 & 0 \\
\hline P78113 & -- & -- & - & -- & -- & -- & -- & -- & - & -- & -- & - & - & 10 & 0 & 0 & 0 & 0 & 0 & 0 \\
\hline P32105 & - & -- & -- & -- & -- & -- & - & -- & - & -- & -- & - & -- & -- & 27 & 1 & 0 & 3 & 0 & 0 \\
\hline P39180 & - & -- & -- & -- & -- & -- & -- & -- & - & -- & -- & -- & -- & -- & -- & 27 & 1 & 0 & 0 & 0 \\
\hline P32102 & -- & -- & -- & -- & -- & -- & -- & - & - & -- & -- & - & -- & -- & -- & - & 13 & 0 & 0 & 0 \\
\hline P34496 & - & -- & -- & -- & -- & -- & - & - & -- & -- & -- & - & -- & -- & -- & - & -- & 23 & 0 & 0 \\
\hline P34488 & - & -- & -- & -- & -- & -- & -- & -- & -- & -- & -- & -- & -- & -- & -- & - & -- & -- & 5 & 0 \\
\hline P34541 & - & - & -- & -- & -- & -- & - & - & -- & -- & -- & -- & -- & -- & -- & - & -- & -- & - & 2 \\
\hline P32104 & -- & -- & -- & -- & -- & -- & -- & - & -- & -- & -- & -- & -- & -- & -- & -- & -- & -- & -- & -- \\
\hline
\end{tabular}


Table 9. Number of samples with volatile organic compound (VOC) pairs detected in river-water samples from individual monitoring stations, Ohio River Basin, 1987-96-Continued

[PCODE, U.S. Environmental Protection Agency Storage and Retrieval (STORET) System parameter code; P32106, trichloromethane; P34030, benzene; P78131, methylbenzene; P34423, dichloromethane; P34566, 1,3-dichlorobenzene; P34531, 1,2-dichloroethane; P34475, tetrachloroethene; P32101, bromodichloromethane; P34571, 1,4-dichlorobenzene; P34536, 1,2-dichlorobenzene; P34301, chlorobenzene; P34501, 1,1-dichloroethene; P34506, 1,1,1-trichloroethane; P78113, ethylbenzene; P32105, dibromochloromethane; P39180, trichloroethene; P32102, tetrachloromethane; P34496, 1,1-dichloroethane; P34488, trichlorofluoromethane; P34541, 1,2-dichloropropane; P32104, tribromomethane; bold numbers indicate percentage of co-occurrences greater than or equal to 20 percent; --, not computed]

Ohio River at Evansville, Ind. (station OR189.5, fig. 1)

PCODE P32106 P34030 P78131 P34423 P34566 P34531 P34475 P32101 P34571 P34536 P34301 P34501 P34506 P78113 P32105 P39180 P32102 P34496 P34488 P34541 P32104

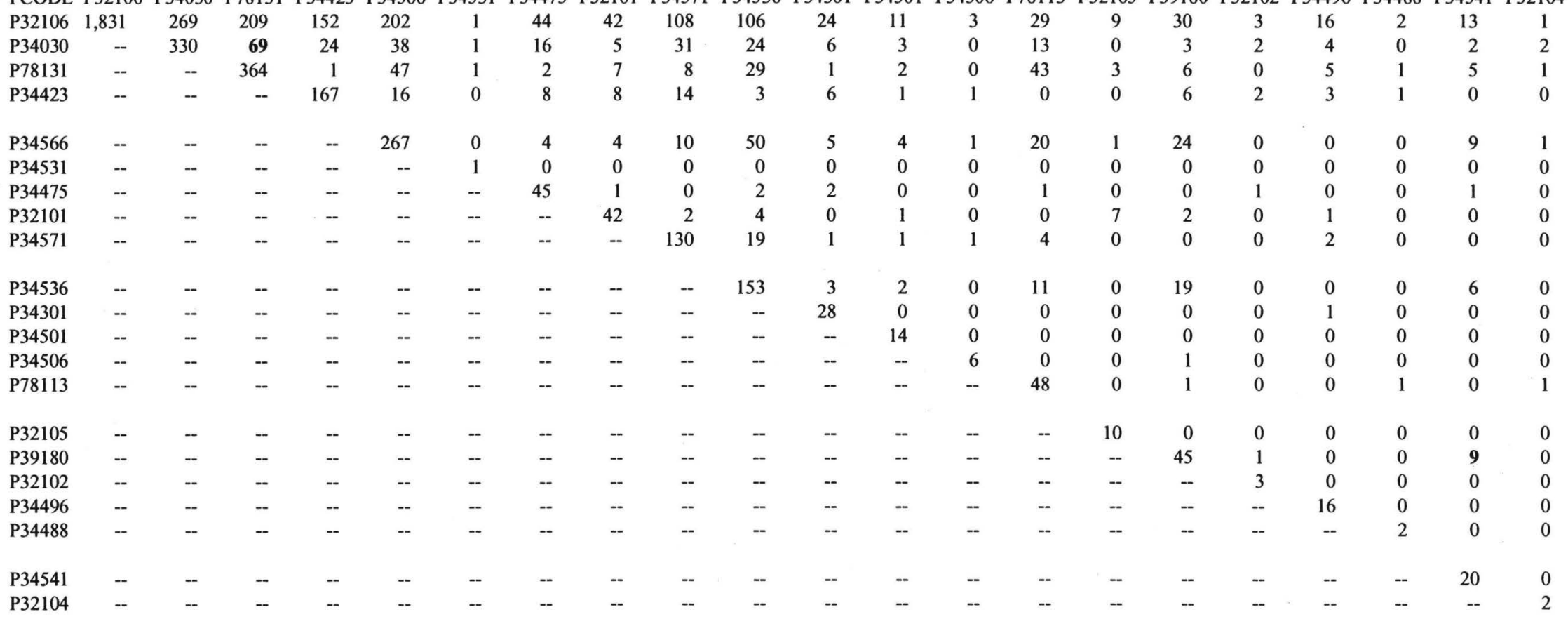


Table 9. Number of samples with volatile organic compound (VOC) pairs detected in river-water samples from individual monitoring stations, Ohio River Basin, 1987-96-Continued

[PCODE, U.S. Environmental Protection Agency Storage and Retrieval (STORET) System parameter code; P32106, trichloromethane; P34030, benzene; P78131, methylbenzene; P34423,

dichloromethane; P34566, 1,3-dichlorobenzene; P34531, 1,2-dichloroethane; P34475, tetrachloroethene; P32101, bromodichloromethane; P34571, 1,4-dichlorobenzene; P34536, 1,2-dichlorobenzene; P34301, chlorobenzene; P34501, 1,1-dichloroethene; P34506, 1,1,1-trichloroethane; P78113, ethylbenzene; P32105, dibromochloromethane; P39180, trichloroethene; P32102, tetrachloromethane;

P34496, 1,1-dichloroethane; P34488, trichlorofluoromethane; P34541, 1,2-dichloropropane; P32104, tribromomethane; bold numbers indicate percentage of co-occurrences greater than or equal to 20 percent; --, not computed]

Ohio River at Paducah, Ky. (station OR45.5, fig. 1)

PCODE P32106 P34030 P78131 P34423 P34566 P34531 P34475 P32101 P34571 P34536 P34301 P34501 P34506 P78113 P32105 P39180 P32102 P34496 P34488 P34541 P32104

\begin{tabular}{|c|c|c|c|c|c|c|c|c|c|c|c|c|c|c|c|c|c|c|c|c|c|}
\hline & & & & & & & & & & & & & & & & & & & & & \\
\hline P32106 & 367 & 3 & 8 & 39 & 1 & 288 & 32 & 6 & 0 & 1 & 0 & 9 & 10 & 1 & 3 & 1 & 8 & 19 & 2 & 0 & 2 \\
\hline P34030 & -- & 31 & 4 & 0 & 0 & 23 & 9 & 0 & 0 & 0 & 0 & 0 & 0 & 1 & 0 & 0 & 0 & 0 & 0 & 0 & 1 \\
\hline P78131 & -- & - & 31 & 1 & 1 & 11 & 1 & 0 & 0 & 1 & 0 & 1 & 1 & 2 & 0 & 0 & 0 & 0 & 1 & 0 & 0 \\
\hline P34423 & -- & -- & -- & 77 & 2 & 63 & 5 & 1 & 0 & 1 & 0 & 7 & 1 & 0 & 0 & 0 & 8 & 3 & 3 & 0 & 0 \\
\hline P34566 & -- & -- & -- & -- & 56 & 19 & 3 & 0 & 3 & 5 & 0 & 10 & 0 & 0 & 0 & 1 & 0 & 1 & 2 & 0 & 0 \\
\hline P34531 & -- & -- & -- & -- & -- & 1,312 & 96 & 3 & 13 & 3 & 0 & 27 & 15 & 2 & 2 & 2 & 10 & 24 & 3 & 0 & 2 \\
\hline P34475 & -- & -- & -- & -- & -- & -- & 116 & 0 & 1 & 0 & 0 & 7 & 3 & 0 & 0 & 1 & 0 & 4 & 0 & 0 & 0 \\
\hline P32101 & -- & -- & -- & -- & -- & -- & -- & 6 & 0 & 0 & 0 & 1 & 0 & 0 & 3 & 0 & 0 & 0 & 0 & 0 & 0 \\
\hline P34571 & -- & -- & - & -- & -- & -- & -- & -- & 22 & 1 & 0 & 3 & 0 & 0 & 0 & 0 & 0 & 0 & 0 & 0 & 0 \\
\hline P34536 & -- & -- & -- & -- & - & - & -- & -- & -- & 14 & 0 & 2 & 0 & 0 & 0 & 0 & 1 & 2 & 0 & 0 & 0 \\
\hline P34301 & -- & -- & -- & -- & -- & -- & -- & -- & -- & -- & 2 & 1 & 0 & 0 & 0 & 0 & 0 & 0 & 0 & 0 & 0 \\
\hline P34501 & -- & -- & -- & -- & -- & -- & -- & -- & -- & - & -- & 70 & 0 & 0 & 1 & 0 & 2 & 0 & 0 & 0 & 1 \\
\hline P34506 & -- & -- & -- & -- & -- & - & -- & -- & -- & -- & -- & -- & 17 & 0 & 0 & 0 & 0 & 0 & 1 & 0 & 0 \\
\hline P78113 & -- & -- & -- & -- & -- & - & -- & -- & -- & - & -- & - & - & 4 & 0 & 0 & 0 & 0 & 0 & 0 & 0 \\
\hline P32105 & -- & -- & -- & - & - & - & -- & - & - & -- & -- & - & - & -- & 4 & 0 & 0 & 0 & 0 & 0 & $\mathbf{1}$ \\
\hline P39180 & -- & -- & -- & -- & -- & -- & -- & -- & - & -- & -- & -- & -- & - & -- & 3 & 0 & 1 & 0 & 0 & 0 \\
\hline P32102 & -- & -- & -- & -- & -- & -- & -- & -- & -- & -- & -- & -- & -- & -- & -- & -- & 12 & 0 & 0 & 0 & 0 \\
\hline P34496 & -- & -- & -- & -- & -- & -- & -- & -- & -- & -- & -- & -- & - & -- & -- & - & -- & 30 & 0 & 0 & 0 \\
\hline P34488 & -- & -- & -- & -- & -- & -- & -- & -- & -- & - & -- & -- & - & -- & -- & -- & -- & -- & 8 & 0 & 0 \\
\hline P34541 & -- & -- & -- & - & -- & -- & -- & -- & - & - & -- & - & - & -- & -- & - & -- & -- & -- & 1 & 0 \\
\hline P32104 & -- & -- & -- & - & -- & -- & -- & -- & -- & -- & -- & - & - & -- & -- & - & -- & -- & -- & - & 4 \\
\hline
\end{tabular}


Table 10. Statistically significant correlations between detected concentrations of volatile organic compounds (VOCs) in river-water samples from individual Ohio River Valley Water Sanitation Commission (ORSANCO) monitoring stations, Ohio River Basin, 1987-96

[STORET, U.S. Environmental Protection Agency Storage and Retrieval System; Note: Correlations computed only for number of detections greater than or equal to $5 ;<$, less than; bold numbers indicate strong correlations greater than 0.7 ]

\begin{tabular}{|c|c|c|c|c|c|}
\hline $\begin{array}{c}\text { Monitoring } \\
\text { station } \\
\text { identifier } \\
\text { (STORET } \\
\text { primary } \\
\text { number) } \\
\text { (fig. 1) }\end{array}$ & Corr & ted VOCs & $\begin{array}{l}\text { Spearman } \\
\text { correlation } \\
\text { coefficient }\end{array}$ & p-value & $\begin{array}{c}\text { Number of } \\
\text { observations }\end{array}$ \\
\hline \multirow[t]{3}{*}{ AR7.40 } & Trichloromethane & Bromodichloromethane & 0.60 & $<0.01$ & 24 \\
\hline & Tetrachloroethene & 1,1-Dichloroethene & .89 & .04 & 5 \\
\hline & Bromodichloromethane & Dibromochloromethane & .66 & $<.01$ & 14 \\
\hline \multirow[t]{13}{*}{ MR4.5 } & Trichloromethane & Benzene & .20 & $<.01$ & 360 \\
\hline & Trichloromethane & Bromodichloromethane & .46 & $<.01$ & 529 \\
\hline & Trichloromethane & Dibromochloromethane & .29 & $<.01$ & 84 \\
\hline & Benzene & Methylbenzene & .46 & $<.01$ & 189 \\
\hline & Benzene & Tetrachloroethene & -.68 & .01 & 13 \\
\hline & Dichloromethane & Tetrachloroethene & .76 & $<.01$ & 139 \\
\hline & Dichloromethane & Bromodichloromethane & .33 & $<.01$ & 76 \\
\hline & Dichloromethane & Tetrachloromethane & -.47 & .01 & 26 \\
\hline & Tetrachloroethene & Bromodichloromethane & .39 & $<.01$ & 44 \\
\hline & Bromodichloromethane & Dibromochloromethane & .56 & $<.01$ & 67 \\
\hline & 1,1-Dichloroethene & Tetrachloromethane & .51 & $<.01$ & 28 \\
\hline & 1,1,1-Trichloroethane & Tetrachloroethene & .99 & $<.01$ & 11 \\
\hline & 1,1,1-Trichloroethane & Trichloroethene & 1.00 & $<.01$ & 5 \\
\hline \multirow[t]{5}{*}{ OR976.50 } & Trichloromethane & Bromodichloromethane & .96 & $<.01$ & 13 \\
\hline & Trichloromethane & Dibromochloromethane & .86 & .01 & 7 \\
\hline & Benzene & 1,2-Dichlorobenzene & .57 & .01 & 19 \\
\hline & Bromodichloromethane & Dibromochloromethane & .74 & .03 & 8 \\
\hline & 1,4-Dichlorobenzene & 1,2-Dichlorobenzene & .58 & $<.01$ & 19 \\
\hline \multirow[t]{9}{*}{ OR946.1 } & Benzene & Methylbenzene & .48 & $<.01$ & 227 \\
\hline & Benzene & 1,2-Dichlorobenzene & .31 & .01 & 67 \\
\hline & Benzene & 1,1-Dichloroethene & .33 & .03 & 44 \\
\hline & Methylbenzene & 1,4-Dichlorobenzene & .49 & $<.01$ & 31 \\
\hline & Methylbenzene & 1,2-Dichlorobenzene & 1.00 & $<.01$ & 11 \\
\hline & Methylbenzene & Ethylbenzene & .40 & $<.01$ & 84 \\
\hline & 1,3-Dichlorobenzene & 1,4-Dichlorobenzene & .64 & $<.01$ & 42 \\
\hline & 1,3-Dichlorobenzene & 1,1-Dichloroethene & -.68 & $<.01$ & 15 \\
\hline & 1,3-Dichlorobenzene & Ethylbenzene & .52 & $<.01$ & 38 \\
\hline \multirow[t]{6}{*}{ OR9408 } & Trichloromethane & Benzene & .35 & $<.01$ & 99 \\
\hline & Trichloromethane & Bromodichloromethane & .69 & $<.01$ & 181 \\
\hline & Trichloromethane & Dibromochloromethane & .60 & $<.01$ & 106 \\
\hline & Tetrachloroethene & Bromodichloromethane & .50 & .02 & 22 \\
\hline & Tetrachloroethene & 1,1,1-Trichloroethane & 1.00 & $<.01$ & 5 \\
\hline & Bromodichloromethane & Dibromochloromethane & .82 & $<.01$ & 121 \\
\hline
\end{tabular}


Table 10. Statistically significant correlations between detected concentrations of volatile organic compounds (VOCs) in river-water samples from individual Ohio River Valley Water Sanitation Commission (ORSANCO) monitoring stations, Ohio River Basin, 1987-96-Continued

[STORET, U.S. Environmental Protection Agency Storage and Retrieval System; Note: Correlations computed only for number of detections greater than or equal to 5 ; <, less than; bold numbers indicate strong correlations greater than 0.7$]$

\begin{tabular}{|c|c|c|c|c|c|}
\hline $\begin{array}{c}\text { Monitoring } \\
\text { station } \\
\text { identifier } \\
\text { (STORET } \\
\text { primary } \\
\text { number) } \\
\text { (fig. 1) }\end{array}$ & Cor & ed VOCs & $\begin{array}{l}\text { Spearman } \\
\text { correlation } \\
\text { coefficient }\end{array}$ & $p$-value & $\begin{array}{l}\text { Number of } \\
\text { observations }\end{array}$ \\
\hline \multirow[t]{11}{*}{ OR9159 } & Trichloromethane & Dibromochloromethane & 0.95 & 0.01 & 5 \\
\hline & Benzene & Dichloromethane & .83 & .01 & 8 \\
\hline & Benzene & 1,3-Dichlorobenzene & .48 & $<.01$ & 34 \\
\hline & Benzene & 1,4-Dichlorobenzene & .50 & .01 & 24 \\
\hline & Benzene & Ethylbenzene & .55 & .03 & 16 \\
\hline & Dichloromethane & 1,3-Dichlorobenzene & .34 & .04 & 37 \\
\hline & 1,3-Dichlorobenzene & 1,4-Dichlorobenzene & .64 & $<.01$ & 66 \\
\hline & Bromodichloromethane & Dibromochloromethane & .91 & $<.01$ & 12 \\
\hline & 1,1-Dichloroethene & Trichloroethene & .95 & $<.01$ & 7 \\
\hline & Dibromochloromethane & Trichloroethene & .50 & .05 & 16 \\
\hline & Trichloroethene & 1,2-Dichloropropane & .71 & $<.01$ & 13 \\
\hline \multirow[t]{7}{*}{ OR894.2 } & Trichloromethane & Benzene & .49 & $<.01$ & 221 \\
\hline & Trichloromethane & 1,1,1-Trichloroethane & .24 & $<.01$ & 199 \\
\hline & Benzene & Methylbenzene & .57 & $<.01$ & 102 \\
\hline & Benzene & Dichloromethane & -.52 & .05 & 15 \\
\hline & Benzene & 1,2-Dichlorobenzene & .45 & .03 & 23 \\
\hline & Benzene & Ethylbenzene & .74 & $<.01$ & 11 \\
\hline & Methylbenzene & 1,2-Dichlorobenzene & .88 & $<.01$ & 15 \\
\hline \multirow[t]{10}{*}{ OR709.7 } & Trichloromethane & 1,4-Dichlorobenzene & .58 & .05 & 12 \\
\hline & Trichloromethane & Chlorobenzene & .25 & .02 & 94 \\
\hline & Benzene & 1,4-Dichlorobenzene & .44 & $<.01$ & 41 \\
\hline & Benzene & 1,2-Dichlorobenzene & .52 & $<.01$ & 55 \\
\hline & Dichloromethane & 1,4-Dichlorobenzene & .72 & .04 & 8 \\
\hline & 1,3-Dichlorobenzene & 1,2-Dichlorobenzene & .50 & $<.01$ & 57 \\
\hline & Bromodichloromethane & 1,2-Dichloropropane & .89 & .04 & 5 \\
\hline & 1,4-Dichlorobenzene & 1,2-Dichlorobenzene & .66 & $<.01$ & 50 \\
\hline & Chlorobenzene & 1,4-Dichlorobenzene & .31 & $<.01$ & 81 \\
\hline & 1,1-Dichloroethene & 1,2-Dichlorobenzene & .40 & .02 & 32 \\
\hline \multirow[t]{10}{*}{ KR38.3 } & Trichloromethane & Benzene & .25 & $<.01$ & 112 \\
\hline & Trichloromethane & Dichloromethane & .65 & .03 & 11 \\
\hline & Trichloromethane & 1,3-Dichlorobenzene & .39 & $<.01$ & 52 \\
\hline & Trichloromethane & Bromodichloromethane & .73 & .01 & 11 \\
\hline & Trichloromethane & Chlorobenzene & -.72 & .04 & 8 \\
\hline & Trichloromethane & Trichloroethene & .40 & .05 & 26 \\
\hline & Trichloromethane & 1,2-Dichloropropane & .63 & $<.01$ & 26 \\
\hline & Benzene & 1,3-Dichlorobenzene & .36 & $<.01$ & 187 \\
\hline & Benzene & Tetrachloroethene & .62 & $<.01$ & 29 \\
\hline & Benzene & 1,4-Dichlorobenzene & .20 & $<.01$ & 177 \\
\hline
\end{tabular}


Table 10. Statistically significant correlations between detected concentrations of volatile organic compounds (VOCs) in river-water samples from individual Ohio River Valley Water Sanitation Commission (ORSANCO) monitoring stations, Ohio River Basin, 1987-96-Continued

[STORET, U.S. Environmental Protection Agency Storage and Retrieval System; Note: Correlations computed only for number of detections greater than or equal to 5 ; $<$, less than; bold numbers indicate strong correlations greater than 0.7 ]

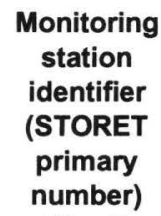

Spearman correlation coefficient p-value

Number of observations

(fig. 1)

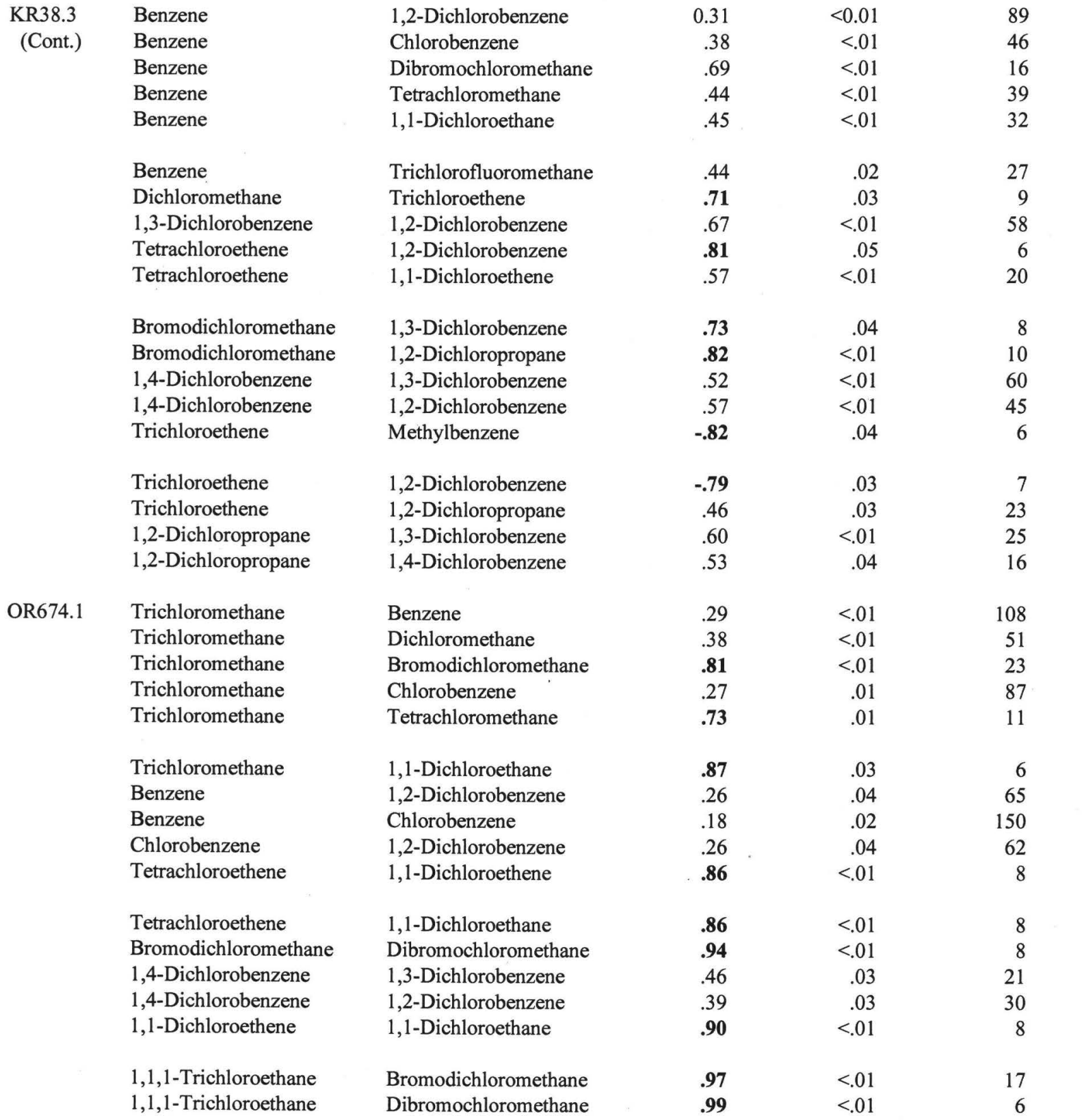


Table 10. Statistically significant correlations between detected concentrations of volatile organic compounds (VOCs) in river-water samples from individual Ohio River Valley Water Sanitation Commission (ORSANCO) monitoring stations, Ohio River Basin, 1987-96-Continued

[STORET, U.S. Environmental Protection Agency Storage and Retrieval System; Note: Correlations computed only for number of detections greater than or equal to $5 ;<$, less than; bold numbers indicate strong correlations greater than 0.7$]$

\begin{tabular}{|c|c|c|c|c|c|}
\hline $\begin{array}{c}\text { Monitoring } \\
\text { station } \\
\text { identifier } \\
\text { (STORET } \\
\text { primary } \\
\text { number) } \\
\text { (fig. 1) }\end{array}$ & Corr & ted VOCs & $\begin{array}{l}\text { Spearman } \\
\text { correlation } \\
\text { coefficient }\end{array}$ & p-value & $\begin{array}{l}\text { Number of } \\
\text { observations }\end{array}$ \\
\hline \multirow[t]{8}{*}{ OR630.9 } & Trichloromethane & Dichloromethane & 0.46 & $<0.01$ & 114 \\
\hline & Trichloromethane & 1,2-Dichloroethane & .58 & $<.01$ & 26 \\
\hline & Trichloromethane & Tetrachloroethene & .29 & $<.01$ & 108 \\
\hline & Benzene & Methylbenzene & .61 & $<.01$ & 22 \\
\hline & Benzene & Tetrachloroethene & .32 & .03 & 46 \\
\hline & Dichloromethane & Tetrachloroethene & .40 & $<.01$ & 76 \\
\hline & 1,3-Dichlorobenzene & 1,4-Dichlorobenzene & .80 & .02 & 8 \\
\hline & 1,3-Dichlorobenzene & Ethylbenzene & .96 & $<.01$ & 6 \\
\hline \multirow[t]{6}{*}{ OR518.2 } & Trichloromethane & 1,1,1-Trichloroethane & .22 & $<.01$ & 229 \\
\hline & Dichloromethane & 1,2-Dichlorobenzene & -.90 & .02 & 6 \\
\hline & Bromodichloromethane & Tetrachloromethane & .60 & .04 & 12 \\
\hline & Tetrachloromethane & Benzene & .70 & .02 & 11 \\
\hline & Tetrachloromethane & Trichloroethene & .51 & $<.01$ & 25 \\
\hline & Tetrachloromethane & Tetrachloromethane & .74 & $<.01$ & 18 \\
\hline \multirow[t]{4}{*}{ OR380.4 } & Trichloromethane & Benzene & .76 & .03 & 8 \\
\hline & Tetrachloroethene & 1,3-Dichlorobenzene & .85 & .02 & 7 \\
\hline & Trichloromethane & Bromodichloromethane & .95 & .01 & 5 \\
\hline & Tetrachloroethene & 1,4-Dichlorobenzene & .93 & $<.01$ & 9 \\
\hline \multirow[t]{8}{*}{ OR189.5 } & Trichloromethane & Benzene & .14 & .02 & 269 \\
\hline & Trichloromethane & Methylbenzene & .23 & $<.01$ & 209 \\
\hline & Trichloromethane & Tetrachloroethene & .35 & .02 & 44 \\
\hline & Trichloromethane & 1,1-Dichloroethene & .75 & $<.01$ & 11 \\
\hline & Benzene & Chlorobenzene & .88 & .02 & 6 \\
\hline & Methylbenzene & 1,3-Dichlorobenzene & .30 & .04 & 47 \\
\hline & 1,3-Dichlorobenzene & 1,2-Dichlorobenzene & .43 & $<.01$ & 50 \\
\hline & 1,4-Dichlorobenzene & 1,2-Dichlorobenzene & .48 & .04 & 19 \\
\hline \multirow[t]{7}{*}{ OR45.5 } & Trichloromethane & 1,2-Dichloroethane & .19 & $<.01$ & 288 \\
\hline & Trichloromethane & Bromodichloromethane & .90 & .01 & 6 \\
\hline & Trichloromethane & 1,1-Dichloroethane & .88 & $<.01$ & 19 \\
\hline & Benzene & 1,2-Dichloroethane & .46 & .03 & 23 \\
\hline & Benzene & Tetrachloroethene & .98 & $<.01$ & 9 \\
\hline & 1,2-Dichloroethane & Tetrachloroethene & .40 & $<.01$ & 96 \\
\hline & 1,2-Dichloroethane & 1,1,1-Trichloroethane & .59 & .02 & 15 \\
\hline
\end{tabular}


Table 11. Human-health concerns, drinking-water regulations, and exceedances of regulations for volatile organic compounds (VOCs) detected in river-water samples from the Ohio River Valley Water Sanitation Commission (ORSANCO) monitoring stations, Ohio River Basin, 1987-96

[IUPAC, International Union of Pure and Applied Chemistry; MCL, Maximum Contaminant Level; THM, trihalomethane; --, not determined]

\begin{tabular}{|c|c|c|c|}
\hline IUPAC compound name & Human-health concern & $\begin{array}{c}\text { MCL }^{1} \\
\text { (micrograms } \\
\text { per liter) }\end{array}$ & $\begin{array}{c}\text { Number } \\
\text { of } \\
\text { exceedances }\end{array}$ \\
\hline Trichloromethane (THM) & Cancer $^{2}$ & ${ }^{4} 100$ & 1 \\
\hline Benzene & Cancer $^{2}$ & 5 & 10 \\
\hline Methylbenzene & Liver, kidney, nervous, circulatory effects ${ }^{2}$ & 1,000 & 0 \\
\hline Dichloromethane & Cancer $^{2}$ & 5 & 18 \\
\hline 1,3-Dichlorobenzene & Liver, kidney, blood cell damage ${ }^{2}$ & -- & -- \\
\hline 1,2-Dichloroethane & Cancer $^{2}$ & 5 & 188 \\
\hline Tetrachloroethene & Cancer ${ }^{2}$ & 5 & 9 \\
\hline Bromodichloromethane (THM) & Cancer $^{2}$ & ${ }^{4} 100$ & 0 \\
\hline 1,4-Dichlorobenzene & Cancer ${ }^{2}$ & 75 & 0 \\
\hline 1,2-Dichlorobenzene & Liver, kidney, respiratory, nervous system effects ${ }^{3}$ & 600 & 0 \\
\hline Chlorobenzene & Nervous system effects ${ }^{2}$ & 100 & 0 \\
\hline 1,1-Dichloroethene & Cancer, liver and kidney effects ${ }^{2}$ & 7 & 17 \\
\hline $1,1,1$-Trichloroethane & Liver, nervous system effects ${ }^{2}$ & 200 & 0 \\
\hline Ethylbenzene & Liver, nervous system effects ${ }^{2}$ & 700 & 0 \\
\hline Dibromochloromethane (THM) & Cancer $^{2}$ & ${ }^{4} 100$ & 0 \\
\hline Trichloroethene & Cancer $^{2}$ & 5 & 1 \\
\hline Tetrachloromethane & Cancer $^{2}$ & 5 & 15 \\
\hline 1,1-Dichloroethane & Circulatory system effects ${ }^{3}$ & -- & -- \\
\hline Trichlorofluoromethane & Mild irritant ${ }^{3}$ & -- & -- \\
\hline 1,2-Dichloropropane & Cancer, liver, and kidney effects ${ }^{2}$ & 5 & 12 \\
\hline Tribromomethane (THM) & Cancer $^{2}$ & ${ }^{4} 100$ & 0 \\
\hline
\end{tabular}

${ }^{1}$ U.S. Environmental Protection Agency, 1994, 1996.

${ }^{2}$ Verschueren, 1983.

${ }^{3}$ Ammore and Hautala, 1983

${ }^{4}$ Applies to the sum of THMs. 
Table 12. Spearman correlation coefficients between stream discharge and detected concentrations of trichloromethane, 1987-96

[ORSANCO, Ohio River Valley Water Sanitation Commission; USGS, U.S. Geological Survey; STORET, U.S. Environmental Protection Agency Storage and Retrieval System; River miles are from the confluence of the Allegheny and Monongahela Rivers; --, not applicable; $<$ less than]

\begin{tabular}{|c|c|c|c|c|c|c|c|c|c|c|}
\hline \multicolumn{4}{|c|}{ ORSANCO monitoring stations } & \multicolumn{4}{|c|}{ Nearest USGS stream-gaging stations } & \multirow{3}{*}{$\begin{array}{l}\text { Number } \\
\text { of } \\
\text { detected } \\
\text { concen- } \\
\text { trations }\end{array}$} & \multirow{3}{*}{ p-value } & \multirow{3}{*}{$\begin{array}{l}\text { Spearman } \\
\text { correlation } \\
\text { coefficient }\end{array}$} \\
\hline \multirow{2}{*}{$\begin{array}{c}\text { Monitoring } \\
\text { station } \\
\text { identifier } \\
\text { (STORET } \\
\text { primary } \\
\text { number) } \\
\text { (fig. 1) }\end{array}$} & \multirow[b]{2}{*}{ Station description } & \multicolumn{2}{|c|}{ River miles } & \multirow{2}{*}{$\begin{array}{c}\text { USGS } \\
\text { station } \\
\text { number } \\
\text { (fig. 1) }\end{array}$} & \multicolumn{2}{|c|}{ River miles } & \multirow[b]{2}{*}{ USGS station name } & & & \\
\hline & & $\begin{array}{l}\text { Ohio } \\
\text { River }\end{array}$ & Tributary & & $\begin{array}{l}\text { Ohio } \\
\text { River }\end{array}$ & Tributary & & & & \\
\hline MR4.5 & $\begin{array}{l}\text { Monongahela River at Becks } \\
\text { Run, Pa. }\end{array}$ & -- & 4.5 & 3085000 & -- & 11.2 & $\begin{array}{l}\text { Monongahela River at Braddock, } \\
\text { Pa. }\end{array}$ & 2,607 & 0.07 & 0.03 \\
\hline OR976.50 & Ohio River at Neville Island, $\mathrm{Pa}$. & 4.5 & - & 3086000 & 13.3 & -- & Ohio River at Sewickley, $\mathrm{Pa}$. & 85 & .005 & -.05 \\
\hline OR630.9 & Ohio River at Portsmouth, Ohio & 350.7 & -- & 3216600 & 341.5 & -- & $\begin{array}{l}\text { Ohio River. at Greenup Dam, } \\
\text { near Greenup, Ky. }\end{array}$ & 380 & .28 & -.02 \\
\hline OR380.4 & Ohio River at Louisville, Ky. & 600.6 & -- & 3294500 & 607.3 & -- & Ohio River. at Louisville, Ky. & 840 & $<.001$ & -.14 \\
\hline OR45.5 & Ohio River at Paducah, Ky. & 935.5 & - & 3611500 & 944.1 & -- & Ohio River. at Metropolis, Ill. & 367 & $<.001$ & -.10 \\
\hline
\end{tabular}


Table 13. Results of seasonal Kendall test for trends on monthly mean concentrations of volatile organic compounds (VOCs) in river-water samples from the Ohio River Valley Water Sanitation Commission (ORSANCO) monitoring stations, Ohio River Basin, 1987-96

[STORET, U.S. Environmental Protection Agency Storage and Retrieval System; $(\mu \mathrm{g} / \mathrm{L}) / \mathrm{yr}$, micrograms per liter per year; <, less than; --, no trend]

\begin{tabular}{|c|c|c|c|c|c|c|c|}
\hline \multirow{2}{*}{$\begin{array}{c}\text { Monitoring } \\
\text { station } \\
\text { identifier } \\
\text { (STORET } \\
\text { primary } \\
\text { number) } \\
\text { (fig.1) }\end{array}$} & \multirow[b]{2}{*}{ Station description } & \multicolumn{3}{|c|}{ Trichloromethane } & \multicolumn{3}{|c|}{ Benzene } \\
\hline & & $\begin{array}{l}\text { Number } \\
\text { of obser- } \\
\text { vations }\end{array}$ & p-value & $\begin{array}{c}\text { Trend } \\
{[(\mu \mathrm{g} / \mathrm{L}) / \mathrm{yr}]}\end{array}$ & $\begin{array}{l}\text { Number } \\
\text { of obser- } \\
\text { vations }\end{array}$ & p-value & $\begin{array}{c}\text { Trend } \\
{[(\mu \mathrm{g} / \mathrm{L}) / \mathrm{yr}]}\end{array}$ \\
\hline AR7.40 & Allegheny River at Pittsburgh, $\mathrm{Pa}$. & 119 & $<0.01$ & -0.02 & -- & -- & -- \\
\hline MR4.5 & Monongahela River at Becks Run, Pa. & 120 & $<.01$ & -.09 & 108 & $<0.01$ & -0.01 \\
\hline OR976.50 & Ohio River at Neville Island, $\mathrm{Pa}$. & -- & -- & -- & -- & -- & -- \\
\hline OR946.1 & Ohio River at Shippingport, $\mathrm{Pa}$. & -- & -- & -- & 82 & $<.01$ & -.02 \\
\hline OR9408 & Ohio River at East Liverpool, Ohio & 66 & $<.01$ & -.17 & -- & -- & -- \\
\hline OR9159 & Ohio River at Weirton, W. Va. & -- & -- & -- & -- & -- & -- \\
\hline OR894.2 & Ohio River at Wheeling, W. Va. & 117 & .02 & -.04 & -- & -- & -- \\
\hline OR790.7 & Ohio River at Parkersburg, W. Va. & -- & -- & -- & 103 & $<.01$ & -.01 \\
\hline KR38.3 & Kanawha River at St. Albans, W. Va. & -- & - & -- & 108 & $<.01$ & -.05 \\
\hline OR674.1 & Ohio River at Huntington, W. Va. & 120 & $<.01$ & .12 & 108 & $<.01$ & -.01 \\
\hline OR630.9 & Ohio River at Portsmouth, Ohio & -- & -- & -- & -- & -- & -- \\
\hline OR518.2 & Ohio River at Cincinnati, Ohio & 120 & $<.01$ & -.02 & -- & -- & -- \\
\hline OR380.4 & Ohio River at Louisville, Ky. & -- & -- & -- & -- & -- & -- \\
\hline OR189.5 & Ohio River at Evansville, Ind. & 120 & $<.01$ & -.03 & -- & -- & -- \\
\hline OR45.5 & Ohio River at Paducah, Ky. & -- & -- & - & -- & -- & -- \\
\hline
\end{tabular}

\begin{tabular}{|c|c|c|c|c|c|c|c|}
\hline \multirow{2}{*}{$\begin{array}{c}\text { Monitoring } \\
\text { station } \\
\text { identifier } \\
\text { (STORET } \\
\text { primary } \\
\text { number) } \\
\text { (fig.1) }\end{array}$} & \multirow[b]{2}{*}{ Station description } & \multicolumn{3}{|c|}{ Methylbenzene } & \multicolumn{3}{|c|}{ Dichloromethane } \\
\hline & & $\begin{array}{l}\text { Number } \\
\text { of obser- } \\
\text { vations }\end{array}$ & p-value & $\begin{array}{c}\text { Trend } \\
{[(\mu \mathrm{g} / \mathrm{L}) / \mathrm{yr}]}\end{array}$ & $\begin{array}{c}\text { Number } \\
\text { of obser- } \\
\text { vations }\end{array}$ & p-value & $\begin{array}{c}\text { Trend } \\
{[(\mu g / L) / y r]}\end{array}$ \\
\hline
\end{tabular}

\begin{tabular}{|c|c|c|c|c|c|c|c|}
\hline AR7.40 & Allegheny River at Pittsburgh, $\mathrm{Pa}$. & -- & -- & -- & -- & -- & -- \\
\hline MR4.5 & Monongahela River at Becks Run, $\mathrm{Pa}$. & -- & -- & - & -- & -- & -- \\
\hline OR976.50 & Ohio River at Neville Island, $\mathrm{Pa}$. & -- & - & -- & -- & -- & -- \\
\hline OR946.1 & Ohio River at Shippingport, $\mathrm{Pa}$. & 63 & $<0.01$ & -0.03 & -- & -- & -- \\
\hline OR9408 & Ohio River at East Liverpool, Ohio & -- & -- & -- & -- & -- & -- \\
\hline OR9159 & Ohio River at Weirton, W. Va. & 61 & $<.01$ & -.03 & -- & -- & -- \\
\hline OR894.2 & Ohio River at Wheeling, W. Va. & -- & -- & -- & -- & -- & -- \\
\hline OR790.7 & Ohio River at Parkersburg, W. Va. & -- & -- & - & -- & -- & -- \\
\hline KR38.3 & Kanawha River at St. Albans, W. Va. & 63 & $<.01$ & -.03 & -- & $\therefore$ & -- \\
\hline OR674.1 & Ohio River at Huntington, W. Va. & -- & -- & -- & -- & -- & -- \\
\hline OR630.9 & Ohio River at Portsmouth, Ohio & -- & -- & -- & -- & -- & - \\
\hline OR518.2 & Ohio River at Cincinnati, Ohio & -- & -- & -- & -- & -- & -- \\
\hline OR380.4 & Ohio River at Louisville, Ky. & -- & -- & -- & 120 & $<0.01$ & -0.01 \\
\hline OR189.5 & Ohio River at Evansville, Ind. & 63 & $<.01$ & -.03 & -- & -- & -- \\
\hline OR45.5 & Ohio River at Paducah, Ky. & -- & -- & -- & -- & -- & -- \\
\hline
\end{tabular}


Table 13. Results of seasonal Kendall test for trends on monthly mean concentrations of volatile organic compounds (VOCs) in river-water samples from the Ohio River Valley Water Sanitation Commission (ORSANCO) monitoring stations, Ohio River Basin, 1987-96-Continued

[STORET, U.S. Environmental Protection Agency Storage and Retrieval System; $(\mu \mathrm{g} / \mathrm{L}) / \mathrm{yr}$, micrograms per liter per year; <, less than; --, no trend]

\begin{tabular}{|c|c|c|c|c|c|c|c|}
\hline \multirow{2}{*}{$\begin{array}{l}\text { Monitoring } \\
\text { station } \\
\text { identifier } \\
\text { (STORET } \\
\text { primary } \\
\text { number) } \\
\text { (fig.1) }\end{array}$} & \multirow{2}{*}{ Station description } & \multicolumn{3}{|c|}{ 1,3-Dichlorobenzene } & \multicolumn{3}{|c|}{ 1,2-Dichloroethane } \\
\hline & & $\begin{array}{l}\text { Number } \\
\text { of obser- } \\
\text { vations }\end{array}$ & p-value & $\begin{array}{c}\text { Trend } \\
{[(\mu g / L) / y r]}\end{array}$ & $\begin{array}{l}\text { Number } \\
\text { of obser- } \\
\text { vations }\end{array}$ & p-value & $\begin{array}{c}\text { Trend } \\
{[(\mu \mathrm{g} / \mathrm{L}) / \mathrm{yr}]}\end{array}$ \\
\hline
\end{tabular}

AR7.40 Allegheny River at Pittsburgh, Pa.

MR4.5

OR976.50

OR946.1

OR9408

OR9159

OR894.2

OR790.7

KR38.3

OR674.1

Monongahela River at Becks Run, Pa.

Ohio River at Neville Island, Pa.

Ohio River at Shippingport, $\mathrm{Pa}$.

Ohio River at East Liverpool, Ohio

OR630.9

OR518.2

OR380.4

OR189.5

OR45.5
Ohio River at Weirton, W. Va.

Ohio River at Wheeling, W. Va.

Ohio River at Parkersburg, W. Va.

Kanawha River at St. Albans, W. Va.

Ohio River at Huntington, W. Va.

Ohio River at Portsmouth, Ohio

Ohio River at Cincinnati, Ohio

Ohio River at Louisville, Ky.

Ohio River at Evansville, Ind.

Ohio River at Paducah, Ky.

$\begin{array}{lll}-- & -- & - \\ -- & -- & - \\ -- & -- & - \\ -- & -- & - \\ -- & -- & - \\ -- & -- & - \\ -- & -- & - \\ -- & -- & - \\ 108 & <0.01 & -0 \\ -- & -- & - \\ & & \\ -- & -- & - \\ -- & -- & - \\ -- & -- & - \\ -- & -- & - \\ -- & -- & -\end{array}$

\section{Monitoring \\ station}

identifier

(STORET

primary

number)

(fig.1)

\author{
Station description
}

AR7.40 Allegheny River at Pittsburgh, Pa.

MR4.5

OR976.50

OR946.1

OR9408

Monongahela River at Becks Run, $\mathrm{Pa}$.

Ohio River at Neville Island, Pa.

Ohio River at Shippingport, $\mathrm{Pa}$.

OR9159

Ohio River at East Liverpool, Ohio

OR894.2

OR790.7

KR38.3

OR674.1

Ohio River at Weirton, W. Va.

Ohio River at Wheeling, W. Va.

Ohio River at Parkersburg, W. Va.

Kanawha River at St. Albans, W. Va.

OR630.9

OR518.2

OR380.4

OR189.5

OR45.5

Ohio River at Portsmouth, Ohio

Ohio River at Cincinnati, Ohio

Ohio River at Louisville, Ky.

Ohio River at Evansville, Ind.

Ohio River at Paducah, Ky.
Tetrachloroethene

Bromodichloromethane

\begin{tabular}{|c|c|c|}
\hline $\begin{array}{l}\text { Number } \\
\text { of obser- } \\
\text { vations }\end{array}$ & p-value & $\begin{array}{c}\text { Trend } \\
{[(\mu \mathrm{g} / \mathrm{L}) / \mathrm{yr}]}\end{array}$ \\
\hline
\end{tabular}

Number

of obser- p-value Trend

vations

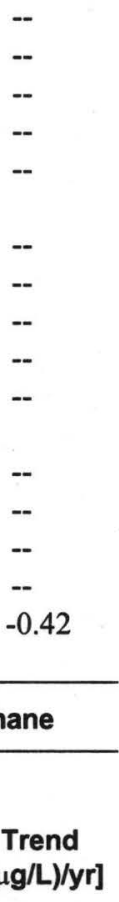

\begin{tabular}{|c|c|c|c|c|c|}
\hline-- & -- & -- & -- & -- & -- \\
\hline-- & -- & -- & 120 & $<0.01$ & -0.02 \\
\hline-- & -- & -- & -- & -- & -- \\
\hline -- & -- & -- & -- & -- & -- \\
\hline-- & -- & -- & 66 & $<.01$ & -.10 \\
\hline -- & _- & -- & -- & -- & -- \\
\hline 17 & $<0.01$ & -0.01 & -- & -- & -- \\
\hline -- & -- & -- & -- & -- & -- \\
\hline -- & -- & -- & - & -- & -- \\
\hline -- & -- & -- & -- & -- & -- \\
\hline -- & -- & -- & -- & -- & -- \\
\hline -- & - & -- & -- & -- & -- \\
\hline -- & -- & -- & - & -- & -- \\
\hline -- & - & -- & -- & -- & -- \\
\hline -- & - & -- & - & -- & -- \\
\hline
\end{tabular}


Table 13. Results of seasonal Kendall test for trends on monthly mean concentrations of volatile organic compounds (VOCs) in river-water samples from the Ohio River Valley Water Sanitation Commission (ORSANCO) monitoring stations, Ohio River Basin, 1987-96-Continued

[STORET, U.S. Environmental Protection Agency Storage and Retrieval System; $(\mu \mathrm{g} / \mathrm{L}) / \mathrm{yr}$, micrograms per liter per year; <, less than; --, no trend]

\begin{tabular}{|c|c|c|c|c|c|c|c|}
\hline \multirow{2}{*}{$\begin{array}{c}\text { Monitoring } \\
\text { station } \\
\text { identifier } \\
\text { (STORET } \\
\text { primary } \\
\text { number) } \\
\text { (fig.1) }\end{array}$} & \multirow[b]{2}{*}{ Station description } & \multicolumn{3}{|c|}{ 1,4-Dichlorobenzene } & \multicolumn{3}{|c|}{ 1,2-Dichlorobenzene } \\
\hline & & $\begin{array}{l}\text { Number } \\
\text { of obser- } \\
\text { vations }\end{array}$ & p-value & $\begin{array}{c}\text { Trend } \\
{[(\mu \mathrm{g} / \mathrm{L}) / \mathrm{yr}]}\end{array}$ & $\begin{array}{l}\text { Number } \\
\text { of obser- } \\
\text { vations }\end{array}$ & p-value & $\begin{array}{c}\text { Trend } \\
{[(\mu \mathrm{g} / L) / \mathrm{yr}]}\end{array}$ \\
\hline
\end{tabular}

$\begin{array}{ll}\text { AR7.40 } & \text { Allegheny River at Pittsburgh, Pa. } \\ \text { MR4.5 } & \text { Monongahela River at Becks Run, Pa. } \\ \text { OR976.50 } & \text { Ohio River at Neville Island, Pa. } \\ \text { OR946.1 } & \text { Ohio River at Shippingport, Pa. } \\ \text { OR9408 } & \text { Ohio River at East Liverpool, Ohio }\end{array}$

OR9159 Ohio River at Weirton, W. Va.

OR894.2 Ohio River at Wheeling, W. Va.

OR790.7 Ohio River at Parkersburg, W. Va.

KR38.3 Kanawha River at St. Albans, W. Va.

OR674.1 Ohio River at Huntington, W. Va.

OR630.9 Ohio River at Portsmouth, Ohio

OR518.2 Ohio River at Cincinnati, Ohio

OR380.4 Ohio River at Louisville, Ky.

OR189.5 Ohio River at Evansville, Ind.

OR45.5 Ohio River at Paducah, Ky.

\section{Monitoring \\ station \\ identifier \\ (STORET \\ primary \\ number)}

(fig.1)

\begin{tabular}{|c|c|c|c|c|c|}
\hline -- & -- & -- & -- & -- & -- \\
\hline -- & -- & -- & -- & -- & -- \\
\hline -- & -- & -- & -- & -- & -- \\
\hline 82 & $<0.01$ & -0.02 & 82 & $<0.01$ & -0.02 \\
\hline -- & - & -- & -- & -- & -- \\
\hline -- & -- & -- & -- & -- & -- \\
\hline -- & -- & -- & -- & -- & -- \\
\hline -- & -- & -- & -- & -- & -- \\
\hline 108 & $<.01$ & -.03 & -- & -- & -- \\
\hline-- & -- & - & -- & -- & -- \\
\hline-- & -- & -- & -- & -- & -- \\
\hline -- & -- & -- & -- & -- & -- \\
\hline -- & -- & - & -- & -- & -- \\
\hline -- & -- & - & -- & -- & -- \\
\hline -- & -- & -- & -- & -- & -- \\
\hline
\end{tabular}

\begin{tabular}{|c|c|c|c|c|c|c|c|}
\hline AR7.40 & Allegheny River at Pittsburgh, $\mathrm{Pa}$. & -- & -- & -- & -- & -- & -- \\
\hline MR4.5 & Monongahela River at Becks Run, Pa. & -- & -- & -- & -- & -- & - \\
\hline OR976.50 & Ohio River at Neville Island, $\mathrm{Pa}$. & -- & -- & -- & -- & -- & -- \\
\hline OR946.1 & Ohio River at Shippingport, $\mathrm{Pa}$. & -- & -- & -- & -- & -- & -- \\
\hline OR9408 & Ohio River at East Liverpool, Ohio & -- & -- & -- & -- & -- & -- \\
\hline OR9159 & Ohio River at Weirton, W. Va. & -- & -- & -- & -- & -- & -- \\
\hline OR894.2 & Ohio River at Wheeling, W. Va. & -- & -- & -- & -- & -- & -- \\
\hline OR790.7 & Ohio River at Parkersburg, W. Va. & 109 & $<0.01$ & -0.01 & -- & -- & -- \\
\hline KR38.3 & Kanawha River at St. Albans, W. Va. & -- & -- & -- & 114 & $<0.01$ & -0.03 \\
\hline OR674.1 & Ohio River at Huntington, W. Va. & -- & -- & -- & -- & -- & -- \\
\hline OR630.9 & Ohio River at Portsmouth, Ohio & -- & -- & -- & -- & -- & -- \\
\hline OR518.2 & Ohio River at Cincinnati, Ohio & -- & -- & -- & -- & -- & -- \\
\hline OR380.4 & Ohio River at Louisville, Ky. & -- & -- & -- & -- & -- & -- \\
\hline OR189.5 & Ohio River at Evansville, Ind. & -- & -- & -- & -- & -- & -- \\
\hline OR45.5 & Ohio River at Paducah, Ky. & -- & -- & -- & -- & -- & -- \\
\hline
\end{tabular}


Table 13. Results of seasonal Kendall test for trends on monthly mean concentrations of volatile organic compounds (VOCs) in river-water samples from the Ohio River Valley Water Sanitation Commission (ORSANCO) monitoring stations, Ohio River Basin, 1987-96-Continued

[STORET, U.S. Environmental Protection Agency Storage and Retrieval System; $(\mu \mathrm{g} / \mathrm{L}) / \mathrm{yr}$, micrograms per liter per year; <, less than; --, no trend]

\begin{tabular}{|c|c|c|c|c|c|c|c|}
\hline \multirow{2}{*}{$\begin{array}{c}\text { Monitoring } \\
\text { station } \\
\text { identifier } \\
\text { (STORET } \\
\text { primary } \\
\text { number) } \\
\text { (fig.1) }\end{array}$} & \multirow[b]{2}{*}{ Station description } & \multicolumn{3}{|c|}{ 1,1,1-Trichloroethane } & \multicolumn{3}{|c|}{ Ethylbenzene } \\
\hline & & $\begin{array}{l}\text { Number } \\
\text { of obser- } \\
\text { vations }\end{array}$ & p-value & $\begin{array}{c}\text { Trend } \\
{[(\mu \mathrm{g} / \mathrm{L}) / \mathrm{yr}]}\end{array}$ & $\begin{array}{l}\text { Number } \\
\text { of obser- } \\
\text { vations }\end{array}$ & p-value & $\begin{array}{c}\text { Trend } \\
{[(\mu \mathrm{g} / \mathrm{L}) / \mathrm{yr}]}\end{array}$ \\
\hline
\end{tabular}

\begin{tabular}{|c|c|c|c|c|c|c|c|}
\hline AR7.40 & Allegheny River at Pittsburgh, $\mathrm{Pa}$. & - & - & - & -- & - & -- \\
\hline MR4.5 & Monongahela River at Becks Run, $\mathrm{Pa}$. & -- & -- & -- & -- & -- & -- \\
\hline OR976.50 & Ohio River at Neville Island, $\mathrm{Pa}$. & -- & -- & -- & -- & - & -- \\
\hline OR946.1 & Ohio River at Shippingport, $\mathrm{Pa}$. & -- & -- & - & 63 & $<0.01$ & -0.03 \\
\hline OR9408 & Ohio River at East Liverpool, Ohio & -- & -- & -- & -- & -- & -- \\
\hline OR9159 & Ohio River at Weirton, W. Va. & -- & -- & -- & -- & - & -- \\
\hline OR894.2 & Ohio River at Wheeling, W. Va. & 117 & $<0.01$ & -0.02 & -- & -- & -- \\
\hline OR790.7 & Ohio River at Parkersburg, W. Va. & -- & -- & -- & -- & -- & -- \\
\hline KR38.3 & Kanawha River at St. Albans, W. Va. & -- & - & - & -- & - & -- \\
\hline OR674.1 & Ohio River at Huntington, W. Va. & -- & -- & -- & -- & -- & -- \\
\hline OR630.9 & Ohio River at Portsmouth, Ohio & -- & -- & -- & -- & -- & -- \\
\hline OR518.2 & Ohio River at Cincinnati, Ohio & -- & -- & - & -- & -- & -- \\
\hline OR380.4 & Ohio River at Louisville, Ky. & -- & -- & -- & -- & -- & -- \\
\hline OR189.5 & Ohio River at Evansville, Ind. & -- & -- & - & -- & -- & -- \\
\hline OR45.5 & Ohio River at Paducah, Ky. & -- & -- & -- & -- & -- & -- \\
\hline
\end{tabular}


Table 14. Results of seasonal Kendall test for trends on monthly percentage of detections in river-water samples from the Ohio River Valley Water Sanitation Commission (ORSANCO) monitoring stations, Ohio River Basin, 198796

[STORET, U.S. Environmental Protection Agency Storage and Retrieval System; \%/yr, percent per year; <, less than; --, no trend]

\begin{tabular}{|c|c|c|c|c|c|c|c|}
\hline \multirow{2}{*}{$\begin{array}{c}\text { Monitoring } \\
\text { station } \\
\text { identifier } \\
\text { (STORET } \\
\text { primary } \\
\text { number) } \\
\text { (fig.1) }\end{array}$} & \multirow[b]{2}{*}{ Station description } & \multicolumn{3}{|c|}{ Trichloromethane } & \multicolumn{3}{|c|}{ Benzene } \\
\hline & & $\begin{array}{l}\text { Number } \\
\text { of obser- } \\
\text { vations }\end{array}$ & p-value & $\begin{array}{l}\text { Trend } \\
(\% / y r)\end{array}$ & $\begin{array}{l}\text { Number } \\
\text { of obser- } \\
\text { vations }\end{array}$ & p-value & $\begin{array}{l}\text { Trend } \\
\text { (\%/yr) }\end{array}$ \\
\hline AR7.40 & Allegheny River at Pittsburgh, $\mathrm{Pa}$. & 119 & $<0.01$ & -1.62 & -- & -- & -- \\
\hline MR4.5 & Monongahela River at Becks Run, $\mathrm{Pa}$. & 120 & $<.01$ & -3.33 & -- & -- & -- \\
\hline OR976.50 & Ohio River at Neville Island, $\mathrm{Pa}$. & -- & -- & -- & -- & -- & -- \\
\hline OR946.1 & Ohio River at Shippingport, Pa. & -- & -- & -- & 82 & $<0.01$ & -4.26 \\
\hline OR9408 & Ohio River at East Liverpool, Ohio & 66 & $<.01$ & -6.72 & -- & -- & -- \\
\hline OR9159 & Ohio River at Weirton, W. Va. & -- & -- & - & -- & -- & -- \\
\hline OR894.2 & Ohio River at Wheeling, W. Va. & 117 & $<.01$ & -6.67 & -- & -- & -- \\
\hline OR790.7 & Ohio River at Parkersburg, W. Va. & -- & -- & - & -- & -- & -- \\
\hline KR38.3 & Kanawha River at St. Albans, W. Va. & -- & -- & -- & 108 & $<.01$ & -7.00 \\
\hline OR674.1 & Ohio River at Huntington, W. Va. & 120 & $<.01$ & -3.85 & 108 & $<.01$ & -1.08 \\
\hline OR630.9 & Ohio River at Portsmouth, Ohio & -- & -- & -- & -- & -- & -- \\
\hline OR518.2 & Ohio River at Cincinnati, Ohio & 120 & $<.01$ & -8.02 & -- & -- & -- \\
\hline OR380.4 & Ohio River at Louisville, Ky. & -- & -- & -- & -- & -- & -- \\
\hline OR189.5 & Ohio River at Evansville, Ind. & 120 & $<.01$ & -9.68 & -- & -- & -- \\
\hline OR45.5 & Ohio River at Paducah, Ky. & 84 & $<.01$ & -1.64 & -- & -- & -- \\
\hline \multirow{2}{*}{$\begin{array}{c}\text { Monitoring } \\
\text { station } \\
\text { identifier } \\
\text { (STORET } \\
\text { primary } \\
\text { number) } \\
\text { (fig.1) }\end{array}$} & \multirow[b]{2}{*}{ Station description } & \multicolumn{3}{|c|}{ Methylbenzene } & \multicolumn{3}{|c|}{ 1,3-Dichlorobenzene } \\
\hline & & $\begin{array}{l}\text { Number } \\
\text { of obser- } \\
\text { vations }\end{array}$ & p-value & $\begin{array}{l}\text { Trend } \\
(\% / y r)\end{array}$ & $\begin{array}{l}\text { Number } \\
\text { of obser- } \\
\text { vations }\end{array}$ & p-value & $\begin{array}{l}\text { Trend } \\
\text { (\%/yr) }\end{array}$ \\
\hline
\end{tabular}

AR7.40 Allegheny River at Pittsburgh, Pa.

MR4.5

OR976.50

OR946.1

OR9408

OR9159

OR894.2

OR790.7

KR38.3

OR674.1

OR630.9

OR518.2

OR380.4

OR189.5

OR45.5
Monongahela River at Becks Run, $\mathrm{Pa}$.

Ohio River at Neville Island, Pa.

Ohio River at Shippingport, $\mathrm{Pa}$.

Ohio River at East Liverpool, Ohio

Ohio River at Weirton, W. Va.

Ohio River at Wheeling, W. Va.

Ohio River at Parkersburg, W. Va.

Kanawha River at St. Albans, W. Va.

Ohio River at Huntington, W. Va.

Ohio River at Portsmouth, Ohio

Ohio River at Cincinnati, Ohio

Ohio River at Louisville, Ky.

Ohio River at Evansville, Ind.

Ohio River at Paducah, Ky.
63

63

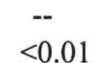

1.61

$<.01$

$-3.57$

61

$<.01$

$-2.22$

63

$<.01 \quad-2.78$

-- --

$-$

$\begin{array}{clc}-- & -- & -- \\ -- & -- & -- \\ -- & -- & -- \\ 63 & <.01 & -12.90 \\ -- & -- & --\end{array}$ 
Table 14. Results of seasonal Kendall test for trends on monthly percentage of detections in river-water samples from the Ohio River Valley Water Sanitation Commission (ORSANCO) monitoring stations, Ohio River Basin, 198796-Continued

[STORET, U.S. Environmental Protection Agency Storage and Retrieval System; \%/yr, percent per year; <, less than; --, no trend]

\begin{tabular}{|c|c|c|c|c|c|c|c|}
\hline \multirow{2}{*}{$\begin{array}{l}\text { Monitoring } \\
\text { station } \\
\text { identifier } \\
\text { (STORET } \\
\text { primary } \\
\text { number) } \\
\text { (fig.1) }\end{array}$} & \multirow[b]{2}{*}{ Station description } & \multicolumn{3}{|c|}{ 1,2-Dichlorethane } & \multicolumn{3}{|c|}{ Bromodichloromethane } \\
\hline & & $\begin{array}{l}\text { Number } \\
\text { of obser- } \\
\text { vations }\end{array}$ & p-value & $\begin{array}{l}\text { Trend } \\
(\% / y r)\end{array}$ & $\begin{array}{l}\text { Number } \\
\text { of obser- } \\
\text { vations }\end{array}$ & p-value & $\begin{array}{l}\text { Trend } \\
\text { (\%/yr) }\end{array}$ \\
\hline
\end{tabular}

\begin{tabular}{|c|c|c|c|c|c|c|c|}
\hline AR7.40 & Allegheny River at Pittsburgh, $\mathrm{Pa}$. & -- & -- & -- & & & \\
\hline MR4.5 & Monongahela River at Becks Run, Pa. & -- & -- & -- & 120 & $<0.01$ & -1.89 \\
\hline OR976.50 & Ohio River at Neville Island, $\mathrm{Pa}$. & -- & -- & -- & -- & -- & -- \\
\hline OR946.1 & Ohio River at Shippingport, $\mathrm{Pa}$. & -- & -- & -- & -- & -- & -- \\
\hline OR9408 & Ohio River at East Liverpool, Ohio & -- & -- & -- & 66 & $<.01$ & -2.42 \\
\hline OR9159 & Ohio River at Weirton, W. Va. & -- & -- & -- & -- & -- & -- \\
\hline OR894.2 & Ohio River at Wheeling, W. Va. & -- & -- & -- & -- & -- & -- \\
\hline OR790.7 & Ohio River at Parkersburg, W. Va. & -- & -- & -- & -- & -- & - \\
\hline KR38.3 & Kanawha River at St. Albans, W. Va. & -- & -- & -- & -- & -- & -- \\
\hline OR674.1 & Ohio River at Huntington, W. Va. & -- & -- & -- & -- & -- & -- \\
\hline OR630.9 & Ohio River at Portsmouth, Ohio & -- & -- & -- & -- & -- & -- \\
\hline OR518.2 & Ohio River at Cincinnati, Ohio & -- & -- & -- & -- & -- & -- \\
\hline OR380.4 & Ohio River at Louisville, Ky. & -- & -- & -- & -- & -- & -- \\
\hline OR189.5 & Ohio River at Evansville, Ind. & -- & -- & -- & -- & -- & -- \\
\hline OR45.5 & Ohio River at Paducah, Ky. & 84 & $<0.01$ & -6.91 & -- & -- & -- \\
\hline
\end{tabular}

\begin{tabular}{|c|c|c|c|c|c|c|c|}
\hline \multirow{2}{*}{$\begin{array}{c}\text { Monitoring } \\
\text { station } \\
\text { identifier } \\
\text { (STORET } \\
\text { primary } \\
\text { number) } \\
\text { (fig.1) }\end{array}$} & \multirow[b]{2}{*}{ Station description } & \multicolumn{3}{|c|}{ 1,4-Dichlorobenzene } & \multicolumn{3}{|c|}{ 1,2-Dichlorobenzene } \\
\hline & & $\begin{array}{l}\text { Number } \\
\text { of obser- } \\
\text { vations }\end{array}$ & p-value & $\begin{array}{l}\text { Trend } \\
(\% / y r)\end{array}$ & $\begin{array}{l}\text { Number } \\
\text { of obser- } \\
\text { vations }\end{array}$ & p-value & $\begin{array}{l}\text { Trend } \\
\text { (\%/yr) }\end{array}$ \\
\hline
\end{tabular}

AR7.40 Allegheny River at Pittsburgh, Pa.

MR4.5 Monongahela River at Becks Run, Pa.

OR976.50 Ohio River at Neville Island, Pa.

OR946.1 Ohio River at Shippingport, Pa.

OR9408 Ohio River at East Liverpool, Ohio

OR9159 Ohio River at Weirton, W. Va.

OR894.2 Ohio River at Wheeling, W. Va.

OR790.7 Ohio River at Parkersburg, W. Va.

KR38.3 Kanawha River at St. Albans, W. Va.

OR674.1 Ohio River at Huntington, W. Va.

OR630.9 Ohio River at Portsmouth, Ohio

OR518.2 Ohio River at Cincinnati, Ohio

OR380.4 Ohio River at Louisville, Ky.

OR189.5 Ohio River at Evansville, Ind.

OR45.5 Ohio River at Paducah, Ky.

$\begin{array}{llllll}-- & -- & - & -- & -- & -- \\ -- & -- & -- & -- & -- & -- \\ -- & -- & - & -- & -- & -- \\ 82 & <0.01 & -1.33 & 82 & <0.01 & -1.26 \\ -- & -- & -- & -- & -- & -- \\ & & & & & \\ -- & -- & -- & -- & -- & - \\ -- & -- & -- & -- & -- & - \\ -- & -- & -- & -- & -- & - \\ 108 & -.01 & -1.22 & -- & -- & - \\ -- & -- & -- & -- & -- & - \\ & & - & - & - & - \\ -- & -- & - & -- & -- & - \\ -- & -- & -- & -- & -- & - \\ -- & -- & -- & -- & -- & - \\ -- & -- & -- & -- & - & - \\ -- & -- & -- & -- & -- & -\end{array}$


Table 14. Results of seasonal Kendall test for trends on monthly percentage of detections in river-water samples from the Ohio River Valley Water Sanitation Commission (ORSANCO) monitoring stations, Ohio River Basin, 198796-Continued

[STORET, U.S. Environmental Protection Agency Storage and Retrieval System; \%/yr, percent per year; <, less than; --, no trend]

\begin{tabular}{|c|c|c|c|c|}
\hline \multirow{2}{*}{$\begin{array}{c}\text { Monitoring } \\
\text { station } \\
\text { identifier } \\
\text { (STORET } \\
\text { primary } \\
\text { number) } \\
\text { (fig.1) }\end{array}$} & \multirow[b]{2}{*}{ Station description } & \multicolumn{3}{|c|}{ Ethylbenzene } \\
\hline & & $\begin{array}{l}\text { Number } \\
\text { of obser- } \\
\text { vations }\end{array}$ & p-value & $\begin{array}{l}\text { Trend } \\
\text { (\%/yr) }\end{array}$ \\
\hline AR7.40 & Allegheny River at Pittsburgh, $\mathrm{Pa}$. & -- & -- & -- \\
\hline MR4.5 & Monongahela River at Becks Run, $\mathrm{Pa}$. & -- & -- & -- \\
\hline OR976.50 & Ohio River at Neville Island, $\mathrm{Pa}$. & -- & -- & -- \\
\hline OR946.1 & Ohio River at Shippingport, Pa. & 63 & $<0.01$ & -1.62 \\
\hline OR9408 & Ohio River at East Liverpool, Ohio & -- & -- & -- \\
\hline OR9159 & Ohio River at Weirton, W. Va. & -- & -- & -- \\
\hline OR894.2 & Ohio River at Wheeling, W. Va. & -- & -- & - \\
\hline OR790.7 & Ohio River at Parkersburg, W. Va. & -- & -- & -- \\
\hline KR38.3 & Kanawha River at St. Albans, W. Va. & -- & -- & -- \\
\hline OR674.1 & Ohio River at Huntington, W. Va. & - & -- & - \\
\hline OR630.9 & Ohio River at Portsmouth, Ohio & -- & -- & -- \\
\hline OR518.2 & Ohio River at Cincinnati, Ohio & -- & -- & - \\
\hline OR380.4 & Ohio River at Louisville, Ky. & -- & -- & - \\
\hline OR189.5 & Ohio River at Evansville, Ind. & -- & -- & - \\
\hline OR45.5 & Ohio River at Paducah, Ky. & -- & -- & -- \\
\hline
\end{tabular}

